\title{
Fair Value As An Avoidable Rule of Corporate Law: Minority Discounts in Conflict Transactions
}

\section{Citation}

John C. Coates IV, Fair Value As An Avoidable Rule of Corporate Law: Minority Discounts in Conflict Transactions, 147 U. Pa. L. Rev. 1251 (1999).

\section{Published Version}

http://scholarship.law.upenn.edu/penn_law_review/vol147/iss6/1/

\section{Permanent link}

http://nrs.harvard.edu/urn-3:HUL.InstRepos:12942308

\section{Terms of Use}

This article was downloaded from Harvard University's DASH repository, and is made available under the terms and conditions applicable to Other Posted Material, as set forth at http:// nrs.harvard.edu/urn-3:HUL.InstRepos:dash.current.terms-of-use\#LAA

\section{Share Your Story}

The Harvard community has made this article openly available.

Please share how this access benefits you. Submit a story.

\section{Accessibility}




\title{
University of Pennsylvania Law Review
}

FOUNDED 1852

Formerly

American Law Register

\section{ARTICLES}

\section{"FAIR VALUE" AS AN AVOIDABLE RULE OF CORPORATE LAW: MINORITY DISCOUNTS IN CONFLICT TRANSACTIONS}

\author{
JOHN C. COATES IVI
}

INTRODUCTION.

I. DELAWARE DISCOUNT LAW IS UNCLEAR.......................................... 1257

A. Appraisal and Entire Fairness ................................................. 1257

B. Fair Value and Fair Price ......................................................... 1260

C. Minority Discounts ................................................................... 1262

1. Legal Discounts and Financial Discounts ................................... 1262

$\dagger$ Assistant Professor, Harvard Law School; B.A. 1986, University of Virginia; J.D., 1989, New York University Law School. All Rights Reserved. (C) 1999. My thanks to Yakov Amihud, Lucian Bebchuk, Bernie Black, Jack Coffee, Michele Cotton, Beth Garreth, Jeff Gordon, Marcel Kahan, Ehud Kamar, David Katz, Geoff Miller, Arthur Pinto, and Roberta Romano for comments and suggestions. My thinking also benefited from my former partners and colleagues at Wachtell, Lipton, Rosen \& Katz, and from oral presentations of earlier drafts at Boalt Hall, Cardozo Law School, Georgetown University Law Center, Harvard Law School, New York University Law School, UCLA School of Law, University of Michigan Law School, University of Pennsylvania Law School, and University of Texas School of Law. The usual disclaimer applies. 
2. Explicit Discounts and Implicit Discounts .................................. 1264

D. Pro Rata Value ...................................................................... 1266

1. Shareholder Level Discounts and Corporate Level Discounts ... 1268

2. Minority Discounts and Control Premiums................................ 1273

a. Control Premiums.................................................................... 1273

b. Relationship Between Discounts and Premiums ..................... 1278

3. Post-Cavalier Oil Case Law ..................................................... 1280

a. Smith v. Shell Petroleum, Inc. and In re Appraisal

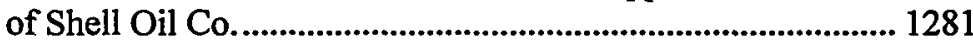

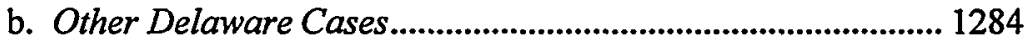

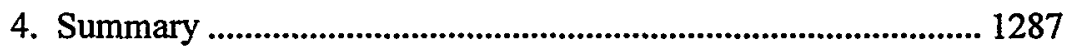

II. DELAWARE DISCOUNT LAW IS AVOIDABLE ........................................ 1287

A. Contracting to Exclude Discounts............................................... 1288

B. Contracting to Include Discounts ................................................ 1289

III. THE PUZZLE OF DISCOUNT LAW ................................................. 1295

A. Firms Have Not Contracted Around Discount Law ....................... 1295

B. Transaction Costs ........................................................................ 1296

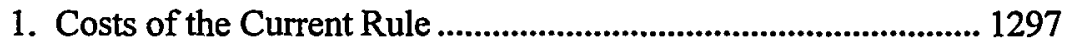

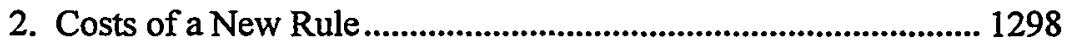

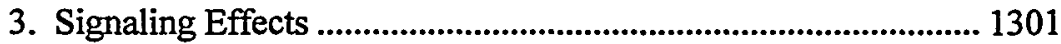

4. Summary of Transaction Costs .............................................. 1303

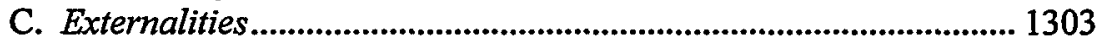

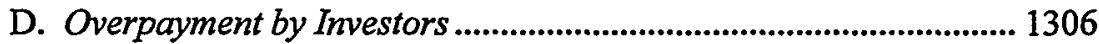

E. Summary-Discount Puzzle .......................................................... 1311

IV. WHAT SHOULD DISCOUNT LAW BE? .............................................. 1311

A. What Are the Costs of Conflict Transactions? .............................. 1313

1. Traditional Social Costs: Rent-Seeking..................................... 1313

2. Wealth Transfers: A Real-World Example ............................... 1318

3. Conflict Transactions Are Nonconsensual and Largely

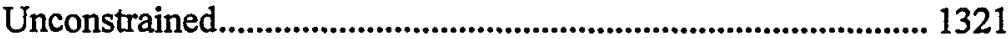

4. Ex Post Social Costs of Pure Wealth Transfers............................ 1323

5. Ex Ante Social Costs of Conflict Transactions .......................... 1325

B. Why Permit Conflict Transactions at All? ..................................... 1327

C. How Do the Costs and Benefits of Conflict Transactions

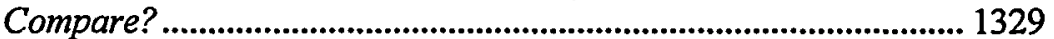

D. What Do Actual Bargains Say About Discounts? ......................... 1332

E. Which Discount Rule Is Fairer? ................................................. 1336

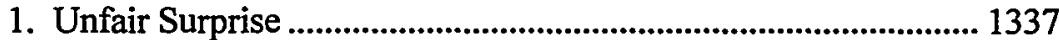

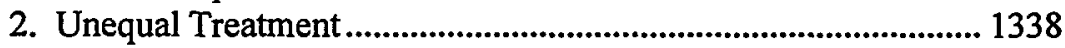

F. Which Discount Rule Is More Feasible? ....................................... 1341

G. Does the Default Nature of Discount Law Affect the Choice of Rule? ....................................................................... 1343

H. Should Discount Law Be Nonmandatory? ................................... 1343

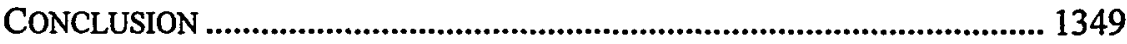




\section{INTRODUCTION}

In 1996, Levi Strauss paid nearly $\$ 4$ billion in cash to its shareholders. ${ }^{1}$ Unusual in size, the freeze-out fit a standard profile-it gave cash and liquidity to most shareholders while allowing the Haas family to obtain $100 \%$ ownership of the firm. At the deal's center was a problem raised in every corporate conflict transaction, ${ }^{2}$ including management buyouts ("MBOs") and parent/subsidiary freeze-outs: How should minority shares be valued? If the share value is set too high, then a transaction will not make sense for continuing shareholders; if it is set too low, then it will not make sense for

${ }^{1}$ See Levi Strauss Assocs. Inc., Schedule 13E-3 (Feb. 14, 1996) <http://www.sec.gov/ Archives/edgar/data/778977/0000950130-96-000512.txt> (visited Feb. 23, 1999) [hereinafter Levi Strauss, Schedule 13E-3]; Levi Strauss Assocs., Inc. Schedule 13E-3 Amendment (Mar. 13, 1996) <http://www.sec.gov/Archives/edgar/data/778977/0000950130-96-000831.txt> (visited Feb. 23, 1999).

2 A "conflict transaction" is a transaction approved by fiduciaries who have a special interest in the transaction and thus are said to "stand on both sides" of the transaction. See Williams v. Geier, 671 A.2d 1368, 1379 (Del. 1996) (stating in dictum that these transactions require the approval of an independent body in order to be protected from shareholder challenges). Management buyouts ("MBOs") put the ongoing management in a direct conflict with the public shareholders because every dollar paid to the shareholders reduces the management's potential profit. See generally Deborah A. DeMott, Puzzles and Parables: Defining Good Faith in the MBO Context, 25 WAKE FOREST L. REV. 15, 15 (1990) (advocating a judicial inquiry using objective and subjective criteria to examine the good faith of MBOs); Louis Lowenstein, Management Buyouts, 85 CoLUM. L. REV. 730, 730 (1985) (assessing the merits of MBOs). Parent/subsidiary freeze-outs involve a similar conflict between the parent company and other shareholders of the subsidiary. See, e.g., Roland Int'l Corp. v. Najjar, 407 A.2d 1032, 1037 (Del. 1979) (affirming a denial of a motion to dismiss a shareholders' suit alleging the breach of a fiduciary duty in a "short-form" merger), overruled by Weinberger $v$. UOP, Inc., 457 A.2d 701 (Del. 1983); Victor Brudney \& Marvin A. Chirelstein, A Restatement of Corporate Freezeouts, 87 YALE L.J. 1354, 1354 (1978) (advocating a rule providing that a parent owes a fiduciary duty to the minority stockholders of its subsidiaries, and proposing "that this duty would not be met unless a corporate purpose for the merger [between the two], other than mere elimination of the minority-held stock, were supported by the evidence").

A "freeze-out" is a transaction in which public shareholders of Firm A are given cash or securities of some other firm in exchange for their stock of Firm A, permitting a controlling shareholder (or management) to gain 100\% ownership of Firm A. Freeze-outs often follow a tender offer in which a third party obtains control. See 1 MARTIN LIPTON \& ERICA H. STEINBERGER, TAKEOVERS AND FREEZEOUTS $§ 9.01$, at 9-3 (1988). Commentators also use the term "freeze-out" in a different manner, to refer to the tactics used by controlling shareholders to disadvantage minority shareholders, for example, by refusing to pay dividends. See generally F. O'NEAL \& J. DERWIN, EXPULSION OR OPPRESSION OF MINORITY SHAREHOLDERS (1961).

Billion dollar conflict transactions have become a common feature of the corporate landscape. In addition to the Levi Strauss buyout, recent examples include the $\$ 2.2$ billion controlled merger of Union Bank and BankCal in 1996 and the \$1.2 billion freeze-outs of QVC and National Gypsum in 1995. See Levi Strauss, Schedule 13E-3, supra note 1; National Gypsum Co., Proxy Statement (Aug. 21, 1995); QVC Programming Holdings, Inc., Offer to Purchase (Aug. 11, 1994). 
continuing shareholders; if it is set too low, then it will not make sense for the shareholders being cashed out. As a rule, huge deals produce huge value disputes, and the Levi Strauss freeze-out proved no exception. Levi Strauss's investment bankers began with an estimated open market value of $\$ 189$ per share. Bankers for dissident shareholders estimated values nearly double that amount, representing a potential value gap of nearly $\$ 2$ billion. $^{3}$

Value disputes often concern facts particular to the target firm-such as its earnings potential or its hidden assets and liabilities. The biggest potential issue in the Levi Strauss value dispute, however, arises each time the minority shares were valued: Should the value be "discounted" to reflect the noncontrolling status of the minority shares? Or, should the value instead equal a pro rata share of the firm's total value?

Minority discounts-which can range as high as $35 \%$ or more ${ }^{4}-$ have a dramatic impact on the price paid in a conflict transaction. If Levi Strauss had included a discount of $35 \%$ in fixing the price paid to the shareholders in its recapitalization, the total payout would have been reduced by nearly $\$ 1.5$ billion. In a copycat financial world strongly influenced by trends and fashions, ${ }^{5}$ in which even the marginal excess returns on investment can at-

3 Initially, the controlling shareholders offered $\$ 250$ per share, a $40 \%$ premium over the company's public market valuation. In February 1996, the company raised its offer to $\$ 265$ per share, in part to reflect increases in overall stock prices since the commencement of the bid. Dillon, Read \& Co., an independent financial advisor retained by a special committee of independent directors to represent the unaffiliated shareholders, found that the $\$ 265$ offer price was within the range of fairness. In early March, the dissident block announced that it might seek a judicial determination of the "fair value" of their shares in an appraisal proceeding under Delaware law. In the end, none of the Levi Strauss shareholders pursued appraisal rights and, after the death of a principal dissident shareholder, the dissident block decided to tender into the company's offer. See Levi Strauss, Schedule 13E-3, supra note 1.

${ }^{4}$ See Perlman v. Permonite Mfg. Co., 568 F. Supp. 222, 226 (N.D. Ind. 1983) (upholding a combined minority and marketability discount of 35\%), affd, 734 F.2d 1283 (7th Cir. 1984); $c f$. BRADFORD CORNELL, CORPORATE VALUATION 240-49 (1993) (collecting empirical data supporting minority discounts ranging from $25 \%$ to $45 \%$ and marketability discounts ranging from $25 \%$ to $60 \%$ ); SHANNON P. PRATT ET AL., VALUING A BUSINESS 316-25, 33463 (3d ed. 1996) (same); Laura G. Boothman, Valuing a Business in a Litigation Context, N.Y. L.J., Feb. 10, 1994, at 5 ("Numerous studies ... support [the marketability] discounts of a wide range, from 0 percent to a high of approximately 80 percent.").

5 See Fischer Black, Noise, 41 J. FIN. 529, 537-38 (1986) (arguing that people mistake noise for information and trade on the basis of that noise, causing "unanticipated shifts in the entire pattern of tastes and technologies across sectors"); Oliver J. Blanchard \& Mark W. Watson, Bubbles, Rational Expectations, and Financial Markets, in CRISES IN THE ECONOMIC AND FRANCIAL STRUCTURE 295, 295 (Paul Wachtel ed., 1982) ("[C]rowd psychology becomes an important determinant of prices."); Bruce N. Lehmann, Fads, Martingales, and Market Efficiency, 105 Q.J. ECON. 1, 25 (1990) ("[T]he suggestion that predictable variation in security returns arises ... from security price overreaction to speculative fads or the cognitive misperceptions of investors in an inefficient market is currently enjoying a resurgence not seen in two decades."); Robert J. Shiller, Fashions, Fads, and Bubbles in Financial Markets, in KNIGHTS, RAIDERS, AND TARGETS 56 (John C. Coffee, Jr. et al. eds., 1988) ("[T]here is 
tract substantial capital, the law on discounts has a dramatic impact not only on the price paid in conflict transactions, but on the extent to which such transactions are pursued at all.

Part I of this Article shows that the law governing minority discounts is surprisingly unpredictable and obscure in spite of the importance of minority discounts. ${ }^{6}$ Even within Delaware, the leading corporate jurisdiction, ${ }^{7}$ a survey of the fair value cases on discounts shows that although the Delaware Supreme Court has rejected minority discounts in theory, Delaware chancery courts have applied them erratically in practice. ${ }^{8}$

Part II argues that although the law of "fair value" widely is thought to be a binding, mandatory element of corporate law, it is not. ${ }^{9}$ Companies and investors need not subject themselves to the currently unclear and unpredictable law regarding discounts. As with nearly all rules of corporate law, firms and investors may contract around the law regarding discounts (a fact that has led Bernard Black to ask whether corporate law should be

evidence that fashions, fads, or bubbles do importantly influence prices of speculative assets.").

${ }^{6}$ Corporate statutes do not address discounts directly. For a long time, the states have been split on the propriety of discounts, and in approximately 20 states, no published decision addresses discounts. Disclosure regarding discounts is nearly nonexistent, and practitioners and commentators are frequently unaware of their potential importance. See infra text accompanying notes $173-90$.

${ }^{3}$ Corporations organized under Delaware law constitute nearly $60 \%$ of the Fortune 500 companies, and one-half of the 30 companies included in the Dow Jones Industrial Average. See generally LEWIS S. BLACK, JR., WHY CORPORATIONS CHOOSE DELAWARE (Prentice Hall Legal \& Fin. Servs. 1993). Courts in other jurisdictions frequently rely on Delaware corporate law. See Mullen v. Academy Life Ins. Co., 705 F.2d 971, 973 n.3 (8th Cir. 1983) ("[W]e discuss Delaware case law as well, because of Delaware's position as a leader in the field of corporate law.").

${ }^{8}$ See infra text accompanying notes 48-120 (discussing Delaware's pro rata value doctrine).

See infra text accompanying notes 123-40 (demonstrating that current Delaware rules on minority discounts are nonbinding). A note on terminology: Legal rules may be divided into (1) mandatory rules, which by their terms apply whether or not the private parties elect to be covered and (2) default rules, which by their terms permit the private parties to "opt out" of the rules. Mandatory rules may be further divided into (a) avoidable rules, which by their terms do not permit "opting out," but which may be avoided (or "contracted around") by the private parties through some (legal) action (or contract) and (b) binding rules, which are impossible or too costly to avoid. Binding rules, finally, may be divided into (i) effective rules, which are practically enforceable and in fact enforced and (ii) hortatory rules, which are either unenforceable or unenforced in practice, where enforcement may be, in part, a function of (illegal) acts of evasion by the private parties. The mandatory/default distinction is usually formal and categorical, whereas the avoidable/binding and effective/hortatory distinctions are usually practical and gradual; a rule may be more or less avoidable or binding, or more or less effective, depending on the costs associated with its avoidance, evasion, and/or enforcement. For convenience, however, I use "nonbinding" and "avoidable" as synonyms, and I often treat them as categorical. 
characterized as "trivial"). Companies can contract around background corporate law regarding fair value determinations by adopting fair price charter provisions, entering into buy/sell agreements, or issuing redeemable stock.

Together, the legal facts reviewed in Parts I and II present an economic puzzle. Ideal rules of corporate law should be consistent. A rule barring discounts might be expected to increase the ex ante share value because investors would pay to eliminate the risk of conflict transactions at discounted prices. Conversely, one could imagine that a rule permitting discounts might increase the ex ante share value by facilitating control transactions. Yet, with few exceptions, issuing firms generally have not used their ability to contract for either rule. ${ }^{10}$ In fact, firms rarely contract around unclear rules of corporate law. In the great majority of instances, firms passively accept the default rules of corporate law, even when those rules are as inconsistent and unclear as Delaware law on discounts.

Part III considers three possible answers to this puzzle, applying concepts from economic theory: transaction costs, network and innovation externalities, and overpayment by investors. ${ }^{11}$ Each suggested answer remains tentative and only points the way for future empirical research, but together these answers suggest that avoidable rules of corporate law may be far from trivial, even when they are nonmandatory or nonbinding.

Whatever the answer to the discount puzzle, a consistent rule on discounts would benefit both investors and firms and improve efficiency. Part IV attempts to provide such a rule. ${ }^{12}$ Although good theoretical arguments can be made for either rule, a rule that excludes discounts is the better candidate for improving social welfare, as well as the private welfare of investors and the largest number of firms. My conclusion is supported by evidence of actual bargains and theoretical approaches for choosing default contract rules that take account of the asymmetric information confronting firms and investors in the securities markets. A rule against discounts also is more likely to reduce transaction costs. Part IV concludes by arguing that discount law should remain nonbinding in the context of initial public offerings.

${ }^{10}$ See infra text accompanying notes 141-44 (discussing the fact that firms generally have not contracted around discount law).

11 See infra notes $145-93$ (discussing possible answers to this puzzle).

12 See infra text accompanying notes 195-294 (describing what discount law should be). 


\section{DELAWARE DISCOUNT LAW IS UNCLEAR}

\section{A. Appraisal and Entire Fairness}

Conflict transactions continue to have wide-ranging effects on the control of public companies in the United States. ${ }^{13}$ Valuing minority shares is at the heart of every conflict transaction. Frequently, the minority shareholders have no choice as to whether they will participate in a given conflict transaction, such as where the transaction is sponsored by a controlling shareholder and no voluntary steps are taken to condition the transaction on approval by the minority shareholders or the independent directors. As a result, the price paid in a conflict transaction often will be neither the result of a true arm's-length negotiation nor otherwise reflect the subjective value placed on the shares by the minority shareholders. ${ }^{14}$ Minority share value is set or negotiated by transaction participants in the shadow of corporate law that provides for two relevant judicial proceedings: ${ }^{15}$ (1) appraisal proceedings under section 262 of the Delaware General Corporation Law ("DGCL") 16 and (2) "entire fairness" cases, in which courts assess whether

13 See Houlihan LoKey Howard \& ZUKIN, MERGERSTAT REVIEW 1997 (1997) [hereinafter MERGERSTAT REVIEW 1997] (collecting data on mergers and acquisitions involving U.S. companies, including data on MBOs and freeze-outs).

${ }^{14}$ Frequently, firms pursuing conflict transactions will set up a special committee of disinterested directors charged with negotiating on behalf of the noncontrolling shareholders. See 1 LIPTON \& STEINBERGER, supra note 2, § 9.07[2], at 9-89. Such "synthetic" negotiations, however, often fail to impress Delaware courts. See, e.g., Kahn v. Lynch Communication Sys., Inc., 638 A.2d 1110, 1117 (Del. 1994) (criticizing the special committee process). Also, skeptics doubt whether even the best-intentioned special committee can substitute for a true market check. See Lowenstein, supra note 2, at 730, 784 (arguing that only a "rule of open bidding would allow the marketplace to determine the fairness issues ... effectively"). In any event, special committees can only negotiate against background law that establishes an amount to which the minority shareholders are entitled in a judicial proceeding.

${ }^{15}$ Stock must also be valued in other corporate contexts (including statutorily or judicially ordered buyouts) as a remedy for the alleged oppression of the minority shareholders, see, e.g., In re Cristo Bros., Inc., 478 N.E.2d 176, 177 (N.Y. 1985) (discussing the legislative intent in determining that a holder of $50 \%$ of a close corporation may exercise a buyout privilege accorded to shareholders), and the fashioning of a judicial remedy in cases where "entire fairness" has not been shown, see Weinberger v. UOP, Inc., No. 5642, 1985 WL 11546, at *9 (Del. Ch. Jan. 30, 1985) (ordering that the stockholders should be compensated even though no precise damages could be calculated). "Fair value" also must be determined outside of corporate law, in tax valuations, loan applications, bankruptcy valuations, property settlements in divorce cases, and takings cases. See PRATT ET AL., supra note 4, at 28 (listing other purposes for valuation, and suggesting standards of value for each); William $P$. Lyons \& Martin J. Whitman, Valuing Closely Held Corporations and Publicly Traded Securities with Limited Marketability: Approaches to Allowable Discounts from Gross Values, 33 Bus. LAW. 2213, 2213-14 (1978) (discussing "fair value" in a tax valuation context).

${ }^{16}$ See DEL. CODE ANN. tit. 8, § 262 (1991) (concerning appraisal rights). Throughout this Article, title 8 of the Delaware Code is sometimes referred to as the "Delaware General 
the shareholders are treated fairly in conflict transactions ${ }^{17}$ such as MBOs and freeze-outs.

Nearly all MBOs and freeze-outs involve either a cash merger, a shortform merger, ${ }^{18}$ or both, and appraisal rights are triggered in Delaware by all short-form mergers and all cash or part-cash mergers. ${ }^{19}$ Appraisal proceedings were not created to address conflict transactions, ${ }^{20}$ nor are they limited to conflict transactions. ${ }^{21}$ Commentators are in general agreement, however, that the most defensible rationale for the continuation of the ap-

Corporation Law" or "DGCL." DGCL section 262 is similar to the appraisal provisions adopted in other states. See 3 MODEL BuS. CORP. ACT ANN. §§ 13.30-31 (1984 \& Supp. 1997) (analyzing appraisal statutes).

17 See Weinberger v. UOP, Inc., 457 A.2d 701, 711-12 (Del. 1983) (holding that the freeze-out did not meet "any reasonable test of faimess"); supra note 2 (defining conflict transactions).

${ }^{18}$ A "short-form merger" is a parent-subsidiary merger on which the subsidiary shareholders are not entitled to vote. See DEL. CODE ANN. tit. 8, $\S 253$ (detailing the law on mergers of parent corporations and their subsidiaries).

${ }_{19}$ See id. $\$ 262(b)$. Some, but not all, stock mergers trigger appraisal rights. DGCL section 262 contains a "market exception" pursuant to which a long-form merger by a public company generally does not trigger appraisal rights unless the stockholders receive in the merger anything other than stock of a public company (and cash in lieu of fractional shares). See id. Finally, a company may voluntarily give the shareholders appraisal rights even when they are not otherwise required, as was done in connection with Fleet Financial Group, Inc.'s acquisition of Fleet Mortgage Group in 1995. See Fleet Financial Group, Inc., Offer to Purchase (Jan. 30, 1995), at 51.

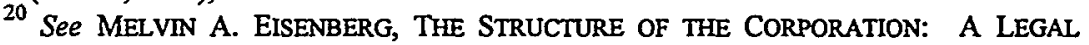
ANALYSIS 78 (1976) (concluding that the appraisal right arose out of a need to reconcile tensions between the majority shareholders' rights "to make drastic changes in the enterprise to meet new conditions as they arise, with the need to protect the minority against being involuntarily dragged along into a drastically restructured enterprise in which it has no confidence"); Mary Siegel, Back to the Future: Appraisal Rights in the Twenty-First Century, 32 HARV. J. ON LEGIS. 79, 92-93 (1995) (positing three possible origins of the appraisal proceeding, none of which concern conflict transactions).

${ }^{21}$ DGCL section 262 is both over- and underinclusive from the perspective of policing conflict transactions - that is, DGCL section 262 is triggered by some nonconflict transactions and is not triggered by some conflict transactions. For example, a long-form stock merger in which the acquiror is a controlling stockholder of the target or is under common control of the management of the target will constitute a conflict transaction and yet not trigger appraisal rights. Conversely, appraisal rights are triggered under DGCL section 262 by some transactions that are not conflict transactions, such as arm's-length long-form cash mergers. Conflict transactions that do not trigger appraisal rights appear, however, to be relatively infrequent. See data from Securities Data Co., Inc. (showing that of 38 parent/subsidiary transactions, including partial and full acquisitions, announced during 1995, only seven involved stock consideration) (on file with author). More commonly, nonconflict transactions that trigger appraisal rights usually do not produce litigation, in part because fiduciaries in nonconflict transactions are not likely to agree to a merger price that represents less than fair value. See MERGERSTAT REVIEW 1997, supra note 13, at 36-38 (noting that 100 arm's-length, cash acquisitions of public companies occurred in 1995 out of a total of 355 , and that 85 involved tender offers, leaving 15 presumably effected by cash mergers). 
praisal remedy is that it polices such transactions, ${ }^{22}$ and the appraisal remedy now is invoked most often in that context. ${ }^{23}$

Not only do conflict transactions frequently give rise to contested appraisal proceedings, but Delaware case law holds that such transactions are not entitled to the protections of the business judgment rule. ${ }^{24}$ Instead, freeze-outs, MBOs, and other conflict transactions are closely scrutinized by the courts under an exacting judicially developed "entire fairness" test. ${ }^{25}$ That test requires the transaction proponent to demonstrate affirmatively that the transaction both is the product of "fair dealing" and reflects a "fair price." 26

Corporate law thus provides shareholders with two different methods of obtaining judicial oversight of the price paid in a conflict transaction. The

22 See, e.g., FRANK H. EASTERBROOK \& DANIEL R. FisCHEL, THE ECONOMIC STRUCTURE OF CORPORATE LAW 145 (1991) (arguing that in policing such transactions, appraisals "increase the welfare of all shareholders"); Robert B. Thompson, Exit, Liquidity and Majority Rule: Appraisal's Role in Corporate Law, 84 GEO. L.J. 1, 4 (1995) ("[T] he [appraisal] remedy serves as a check against opportunism by a majority shareholder in mergers and other transactions in which the majority forces minority shareholders out of the business and requires them to accept cash for their shares."); cf. 2 PRINCIPLES OF CORPORATE GOVERNANCE: ANALYSIS AND RECOMMENDATIONS § 7.22(b), at 638 (providing appraisal rights for nonconflict transactions, but defining "fair value" as a price approved by the board of directors in all transactions other than conflict transactions).

${ }^{23}$ Of the appraisal cases during the years 1984 to 1994 , "more than eighty percent involved cash-outs; only six arose in transactions between independent corporations in which shareholders had the opportunity to continue." Thompson, supra note 22, at 25-26.

${ }^{24}$ Generally speaking, the business judgment rule protects directors making business decisions from being second-guessed by a court. See Cede \& Co. v. Technicolor, Inc., 634 A.2d 345,360 (Del. 1994) (discussing how the rule "operates to preclude a court from imposing itself unreasonably on the business and affairs of a corporation"). See generally DENNIS J. BLOCK ET AL., THE BUSINESS JUDGMENT RULE: FIDUCIARY DUTIES OF CORPORATE DIRECTORS 7-8 (4th ed. 1993) (explaining that the business judgment rule "provides directors the broad discretion they need in formulating dynamic and effective company policy without fear of judicial second-guessing").

${ }^{25}$ See Bershad v. Curtiss-Wright Corp., 535 A.2d 840, 845 (Del. 1987) ("When a majority shareholder stands on both sides of a transaction, the requirement of fairness is 'unflinching' in its demand that the controlling stockholder establish the entire faimess of the undertaking sufficient to pass the test of careful scrutiny by the courts."). Entire faimess litigation also almost always arises out of conflict transactions. In Technicolor, the Delaware Supreme Court stated for the first time that the burden of proving "entire fairness" may arise where fiduciaries have breached their duties of care. See Technicolor, 634 A.2d at 367-71 (finding that the board of directors breached their duty of care). Aside from Technicolor, however, all other reported Delaware decisions applying the "entire faimess" standard involve conflict transactions. See EDWARD P. WELCH \& ANDREW J. TUREZYN, FOLK ON THE DELAWARE GENERAL CORPORATION LAW: FUNDAMENTALS $§ 141.2$, at 79-190 (1994) (discussing, prior to the Technicolor decision, "entire faimess" solely in terms of conflict transactions).

${ }^{26}$ Technicolor, 634 A.2d at 361 ("Under the entire fairness standard ... the defendant directors must establish to the court's satisfaction that the transaction was the product of both fair dealing and fair price." (citing Nixon v. Blackwell, 626 A.2d 1366, 1376 (Del. 1993))). 
case law arising out of these two types of judicial proceedings is the background against which value disputes between minority shareholders and sponsors of conflict transactions are resolved. It is to this case law that participants in the Levi Strauss transaction turned in deciding whether minority shareholders were to be paid a discounted price of $\$ 2.5$ billion or an undiscounted price of $\$ 4$ billion.

\section{B. Fair Value and Fair Price}

Appraisal statutes entitle shareholders to a cash amount determined by reference to the "fair value" of the stock. "Fair value" is determined by a court, and is not defined in statutes. ${ }^{27}$ Beginning in 1983 with Weinberger v. UOP, Inc., Delaware courts have developed an open-ended definition of "fair value" that requires the appraising court to consider "techniques... generally considered accepted in the financial community and otherwise admissible in court, subject only to [the court's] interpretation of [DGCL section 262]."28 Fair value may thus include consideration of the asset, market, and earnings values; future prospects; and any other element affecting "intrinsic value.",29

Since Weinberger, Delaware courts have considered various valuation methodologies proposed by the parties and their experts. Neither the Delaware legislature nor the Delaware courts have shaped or restricted valuation generally; methodological choices are made by the fact-finder on a case-by-

${ }^{27}$ DGCL section 262(h) simply reads:

[T] element of value arising from the accomplishment or expectation of the merger or consolidation, together with a fair rate of interest, if any, to be paid upon the amount determined to be the fair value. In determining such fair value, the Court shall take into account all relevant factors.

DEL. CODE ANN. tit. 8, § 262(h) (1991); see also MODEL BUS. CORP. ACT ANN. $§ 13.01$ (1997) (leaving "fair value" defined as simply "the value of the shares immediately before the effectuation of the corporate action" at issue, excluding changes in value "in anticipation of" an appraisal trigger "unless exclusion would be inequitable"). Thirty-eight states have adopted these definitions. See id.

${ }_{28}$ Weinberger v. UOP, Inc., 457 A.2d 701, 713 (Del. 1983).

29 Id. "[M] arket value, asset value, dividends, earnings prospects, the nature of the enterprise and any other facts which were known or which could be ascertained ... and which throw any light on future prospects of the merged corporation ... must be considered ...."' Id. (quoting Tri-Continental Corp. v. Battye, 74 A.2d 71, 72 (Del. 1950)). 
case basis. ${ }^{30}$ With the prominent exception of discounts and control premiums, ${ }^{31}$ everything is permitted, nothing forbidden. ${ }^{32}$

In entire fairness cases, corporate fiduciaries are required to show that the terms of a proposed conflict transaction include a "fair price," and Delaware courts look to appraisal cases for guidance in deciding whether a given price is fair, even when a merger does not trigger appraisal rights. Delaware courts have stated that "fair value" in an appraisal proceeding will be a "fair price" in an entire fairness case. ${ }^{33}$ That is not to say that a price

${ }^{30}$ See In re Shell Oil Co., 607 A.2d 1213, 1219 (Del. 1992) ("The appraisal quest at the Court of Chancery level admits of a broad latitude."); Weinberger, 457 A.2d at 713 ("At the appellate level, ... we impart a 'high level of deference' to that court's findings." (quotingKahn v. Household Acquisition Corp., 591 A.2d 166, 175 (Del. 1991))).

${ }^{31}$ See infra text accompanying notes 48-122 (discussing Delaware's approach to discounts and control premiums).

32 Or nearly nothing. Delaware courts have recognized that book value, which is based on historical accounting methods, is not a meaningful measure of fair value, which is focused on current and nonspeculative, prospective value. See Seagraves v. Urstadt Property Co., C.A. No. 10307, 1996 WL 159626, at *7 (Del. Ch. Apr. 1, 1996) ("Book value is not a meaningful measure of a corporation's intrinsic or fair value."); David J. Greene \& Co. v. Schenley Indus., Inc., 281 A.2d 30, 34 (Del. Ch. 1971) (noting that "book value is largely ignored by the investor as a guide to fair value," and that "market price ... is ... the most significant element to be taken into consideration in reaching a judgment on the overall fairness of a corporate merger"). Delaware courts have also established that exclusive reliance on market value is incorrect, see Chicago Corp. v. Munds, 172 A. 452, 457 (Del. Ch. 1934) (concluding that a determination of value "founded solely on market quotations to the exclusion of all other relevant evidence" is an insufficient calculation), and that market prices should not be used where the prices were not established in an active, liquid, and efficient market, see Universal City Studios, Inc. v. Francis I. DuPont \& Co., 334 A.2d 216, 221 (Del. 1975) (allowing a valuation based on an industry price-eamings ratio in the absence of a valid market price).

See Alabama By-Products Corp. v. Neal, 588 A.2d 255, 258 n.1 (Del. 1991) ("If a particular merger price would not be 'entirely fair' in an equitable action claiming breach of fiduciary duty, no different result should obtain in an appraisal, where the issue is whether that identical merger price constitutes 'fair value."' (quoting Pinson v. Campbell-Taggart, Inc., C.A. No. 7499, 1989 WL 17438, at *7 (Del. Ch. Feb. 28, 1989))); Cavalier Oil Corp. v. Harnett, 564 A.2d 1137, 1144 (Del. 1989) ("The faimess concept has been said to implicate two considerations: fair dealing and fair price."); Bershad v. Curtiss-Wright Corp., 535 A.2d 840, 845 (Del. 1987) (stating that in an entire fairness case, the concept of fair price "flow[s] from" the requirements of DGCL section 262); Weinberger, 457 A.2d at 711-14 (noting without approval or disapproval that the Chancery Court below held fair value and fair price to be the same); Kahn v. Tremont Corp., C.A. No. 12339, 1996 WL 145452, at *9-10 \& nn.14-17 (Del. Ch. Mar. 21, 1996) (citing DGCL section 262 and appraisal cases and applying the pro rata value doctrine in determining whether the deal price constituted a "fair price"), rev'd on other grounds, 694 A.2d 422 (Del. Super. C. 1997); see also Joseph Evan Calio, New Appraisals of Old Problems: Reflections on the Delaware Appraisal Proceeding, 32 AM. BUS. L.J. 1, 13 (1994) (noting the equivalence of fair value and fair price); Leonard Chazen, Fairness from $a$ Financial Point of View in Acquisitions of Public Companies: Is 'Third-Party Sale Value' the Appropriate Standard?, 36 BUS. LAW. 1439, 1444 (1981) (noting the equivalence of fair value and fair price in pre-Weinberger cases). 
approved as "fair" in a given conflict transaction will always precisely equal fair value as determined in a related appraisal, ${ }^{34}$ but nothing in the Delaware case law suggests that "fair price" and "fair value" should diverge on the question of discounts or premiums.

\section{Minority Discounts}

In both appraisal proceedings and entire fairness cases, determining "fair value" necessarily involves the question whether or not to apply a "discount." As will be seen in Part I.D, the case law on discounts reflects the confusion that stems from the use of undefined or inconsistent terminology. A brief discussion of what "discounts" are will be helpful before reviewing and analyzing that case law.

\section{Legal Discounts and Financial Discounts}

Discounts have roles in both financial markets and judicial proceedings. In financial markets, otherwise identical stock will change hands at different prices depending on whether the stock is part of a control block. ${ }^{35}$ Minority discounts are reflected in nearly all stock market prices, since such prices generally reflect the average marginal trading prices for small amounts of stock that do not convey control. ${ }^{36}$ In addition, courts must decide whether

34 In fact, they will diverge for several reasons: (1) where a fiduciary seeks to avoid "entire faimess" review by appointing a committee of independent directors to negotiate on behalf of the minority shareholders, the committee is commanded by Delaware law to seek the "best price" reasonably obtainable, so long as that price is also a fair price, see In re First Boston, Inc. Shareholders Litig., Civ. A. No. 10338, 1990 WL 201388 (Del. Ch. Dec. 13, 1990) (implying that the "best" deal price may exceed the minimum required to constitute "fair price" or "fair value"); (2) a back-end merger price in a two-step takeover is frequently set to equal the first-step tender offer price in order to avoid SEC Rule 13e-3 or as a result of negotiations, see, e.g., INTERNATIONAL BUSINESS MACHINES CORP., Supplement to Offer to Purchase, at 2 (June 13, 1995); and (3) fiduciaries may also choose to pay more than fair value for a number of reasons, whether from obligations arising out of nonlegal norms (as may often happen in the context of family- or employee-owned firms), to minimize the risk of litigation or criticism, to enhance the fiduciaries' reputations, or in exchange for some other extratransactional benefit.

${ }^{35}$ In addition to minority discounts, commentators have noted other types of discounts relevant to fair value determinations. Most prominent is a type of discount variously called a "marketability discount," a "nonmarketability discount," and an "illiquidity discount." See, e.g., PRATT ET AL., supra note 4, at 331-65 (discussing the concept of, and empirical evidence for, marketability discounts in financial markets). This type of discount reflects the fact that buyers are willing to pay more for stock that is more freely salable than for otherwise identical stock that is less freely salable.

${ }^{36}$ See id. at 304-05 (stating that publicly traded minority share prices reflect an implicit minority discount and that most merger and acquisition transaction data and adjusted net asset values reflect implicit control premiums); see also Michael J. Barclay \& Clifford G. Holder- 
or not valuations should be adjusted (for a given legal purpose) to reflect the characteristics of the shares, or the holders of the shares, being valued. In general terms, a minority discount for legal purposes is an adjustment downward from some reference value, reflecting (at least in part) risks associated with a minority position in a corporation. ${ }^{37}$ Reference values may be

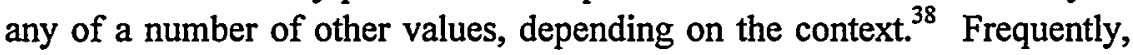
discounts are expressed as a percentage of a reference value, and courts have upheld discounts from $5 \%$ to as high as $35 \%{ }^{39}$

Courts and commentators sometimes seem confused about whether they are using the term "discount" in a legal sense or in a financial sense, and courts sometimes appear (without explanation or even awareness) to impose (legal) discounts solely because of the existence of discounts in the financial markets. ${ }^{40}$ Although there may be reasons to choose a particular legal dis-

ness, Private Benefits from Control of Public Corporations, 25 J. FIN. ECON. 371, 372 (1989) (noting that large share blocks trade at a substantial premium to minority shares).

37 See J.A.C. Hetherington \& Michael P. Dooley, Illiquidity and Exploitation: A Proposed Statutory Solution to the Remaining Close Corporation Problem, 63 VA. L. REV. 1, 6 (1977) ("[L]egal limits on the majority's conduct are generous, and the right of the excluded faction to obtain relief is dependent on its ability to prove that the limits have been overstepped."); Zenichi Shishido, The Fair Value of Minority Stock in Closely Held Corporations, 62 FORDHAM L. REV. 65, 82-83, 102-03 (1993) (noting that minority shareholders are subject to the risks that the corporation will (1) retain dividends even where this does not maximize the share value and (2) pay "hidden cash flow" benefits to the majority shareholders, through excessive compensation or other forms).

${ }^{38}$ Reference values include comparable company market value, market value, asset value, liquidation value, replacement value, and earnings or going concern value. Different courts have found each of these reference values to be relevant in calculating fair value, and these reference values can vary widely. See, e.g., Piemonte v. New Boston Garden Corp., 387 N.E.2d 1145, 1148 n.3 (Mass. 1979) (considering per-share values ranging from $\$ 26.50$ to \$103.16); Taines v. Gene Barry One Hour Photo Process, 474 N.Y.S.2d 362, 365 (Sup. Ct. 1983 ) (considering the total amount of reported business valuations, ranging from $\$ 71,000$ to \$20.7 million); Note, Valuation of Dissenters' Stock Under Appraisal Statutes, 79 HARV. L. REV. 1453, 1469 (1966) (collecting values derived by appraisals using various methodologies in reported Delaware cases from 1947 through 1965, and noting that in one case, per-share values ranged from nearly $\$ 12$ to over $\$ 46)$.

39 See Stanton v. Republic Bank, 581 N.E.2d 678, 681-83 (Ill. 1991) (upholding a minority discount of $5 \%$ and a marketability discount of $5 \%$, for a total discount of $10 \%$ ); Perman v. Permonite Mfg. Co., 568 F. Supp. 222, 226 (N.D. Ind. 1983) (upholding combined minority and marketability discount of 35\%), affd, 734 F.2d 1283 (7th Cir. 1984); see also, e.g., CORNELL, supra note 4, at 239-67 (collecting empirical studies supporting discounts ranging from 25\% to 80\%); PRATT ET AL., supra note 4, at 316-21, 334-63 (collecting empirical data supporting minority discounts that ranged from $25 \%$ to $45 \%$ and marketability discounts that ranged from $25 \%$ to $60 \%$ ); Boothman, supra note 4, at 6 ("Numerous studies . . . support [marketability] discounts of a wide range, from 0 percent to a high of approximately 80 percent.").

${ }^{40}$ See, e.g., Perlman, 568 F. Supp. at 230-32 (upholding a minority discount on the ground that a minority stake, in fact, trades at a discount in the market, reflecting a lack of control); see also CORNELL, supra note 4, at 239-67 (tying explicitly the normative legitimacy 
count on the basis of financial discounts, the two concepts are nonetheless distinct. $^{41}$ To illustrate this, note that if lawmakers universally were to include discounts in fair value determinations, then discounts in the financial markets would likely increase as a result, because minority shares would be subject to freeze-outs at fair values reflecting a legal discount. If, however, lawmakers universally were to exclude discounts in fair value determinations, then discounts in the financial markets would likely decrease (or remain the same) but would continue to exist. Control shares would continue to carry different-and overwhelmingly superior-practical and legal rights and powers than minority shares. ${ }^{42}$ Among other things, control shares convey the right to decide when to engage in a freeze-out, which is a decision minority shareholders are powerless to effect. ${ }^{43}$ Minority shares also lack the ability to force a sale of the firm. The legal question regarding whether or not discounts are permissible in fair value determinations is only one of many ways that the value of minority shares in the financial markets might diverge from the value of control shares. The existence of financial discounts is thus independent of the existence of legal discounts.

\section{Explicit Discounts and Implicit Discounts}

A legal discount can be explicit or implicit. An explicit discount is straightforward. A court might, for example, determine "fair value" by first deriving a reference value by balancing various values (the "Delaware block method," for example, requires weighting asset value, market value, and earnings value ${ }^{44}$, and then reducing the reference value by some percentage

of including control premiums and minority discounts in appraisal proceedings to their existence in financial markets); cf. Rapid-American Corp. v. Harris, 603 A.2d 796, 805 (Del. 1992) (" $[T]$ he full value of the corporate assets to the corporation is not the same as the value of those assets to the common stockholder because of the factor of discount. To fail to recognize this conclusion ... is to fail to face the economic facts and to commit error." (quoting Tri-Continental v. Bettye, 74 A.2d 71, 76 (Del. 1950))).

${ }^{41}$ See, e.g., Moore v. New Ammest, Inc., 630 P.2d 167, 177 (Kan. Ct. App. 1981) (noting that the normative legal validity of a discount was not linked to the descriptive fact of discounts in the financial markets).

42 See supra text accompanying note 37; infra text accompanying notes 71-83.

${ }^{43}$ See 1 LIPTON \& STEINBERGER, supra note $2, \S \S 9.01-.08$. Recent work by Lucian Bebchuk and Marcel Kahan suggests that such a right is worth more than intuition might suggest. See Lucian Arye Bebchuk \& Marcel Kahan, The "Lemon's Effect" in Corporate FreezeOuts, at 5 (Jan. 1998) (unpublished working paper, on file with author) ("[T]he pre-freeze out market price of minority shares will be substantially below the expected 'intrinsic' value of the minority shares absent a freeze-out.").

${ }^{44}$ Although the Delaware block method was critiqued in Weinberger v. UOP, Inc., 457 A.2d 701, 713-15 (Del. 1983), and is generally no longer used in Delaware, it continues to be used in other states and remains permissible even in Delaware. See, e.g., Richardson v. Palmer Broad. Co., 353 N.W.2d 374 (Iowa 1984) (defending and using the Delaware block 
(for example, thirty percent), which is the discount. An explicit discount occurs in what is sometimes referred to as a "second-stage" valuation, ${ }^{45}$ the first stage being the determination of the reference value and the second stage being the explicit application of the discount.

An implicit legal discount occurs when the two valuation stages are performed in a single step. For example, a court might determine "fair value" on the basis of actual trading prices for the shares of companies that are comparable to the company being valued. If, as is typically the case, those trading prices already reflect a financial discount, ${ }^{46}$ then the fair value produced by the valuation will include an implicit legal discount. In this way, financial discounts quietly can produce legal discounts. To detect the presence of an implicit discount, it is necessary to analyze the valuation methodology being employed in order to determine whether the methodology uses values that already reflect discounts in some way. ${ }^{47}$

method); Leader v. Hycor, Inc., 479 N.E.2d 173, 178 (Mass. 1985) (approving of the "Delaware block" method of stock valuation).

${ }_{45}$ See, e.g., Robert B. Heglar, Note, Rejecting the Minority Discount, 1989 DUKE L.J. 258, 266 (arguing against the use of second-stage adjustments for minority discounts); Christopher Vaeth, Propriety of Applying Minority Discount to Value of Shares Purchased by Corporation or Its Shareholders from Minority Shareholders, 13 A.L.R. 5TH 840, 849, 855 (1995) (discussing cases that address discounting the value of minority shares).

46 See PRATT ET AL., supra note 4, at 304-05 (stating that publicly traded minority share prices reflect an implicit minority discount and that most merger and acquisition transaction data and adjusted net asset values reflect control premiums); Rapid-American Corp. v. Harris, 603 A.2d 796, 804-07 (Del. 1992) (same); infra note 59 (discussing the Harris case).

Where a company is the subject of takeover speculation, the minority share market prices may rise in anticipation of a sale reflecting a control premium. For companies with no controlling shareholder, the market prices will be bid up to a level reflecting an estimate of the risk that the sale will not occur and the expected time value to closing. For companies with controlling shareholders, market prices will also reflect the risk that an acquiror will purchase control directly from the controlling shareholder, as well as the possibility that the new controlling shareholder will deal more or less fairly with the minority shareholders as compared to the current controlling shareholder. See Lucian Arye Bebchuk, Efficient and Inefficient Sales of Corporate Control, 109 Q.J. ECON. 957, 961-64 (1994) (exploring certain controlshifting transactions where the controlling interest in a corporation is sold from one shareholder party to another).

47 Courts and commentators speak of the "intrinsic," "fundamental," or "true" value of stock. To the extent that such terms purport to refer to a determinable or Platonic value unrelated to a given set of choices about the measure of value in a given legal context, such terms are misleading at best. Assessing value involves judgments about methodologies, uncertain financial events, and the business prospects of the issuing firm. These are judgments about which even reasonable people will disagree. Assessing value also requires legal judgments. "Market value," as often used, may seem to provide an empirical basis for "real" value, but it, too, reflects judgments that lawmakers have made and continue to make about the corporation. Financial markets also reflect the costs and effectiveness of the mechanisms for policing such judgments. Corporate law, for example, contains numerous vague principles which continue to develop, and people can be surprised by such developments, which implies that people can be expected to have different views as to the value of stock based on their assessments 


\section{Pro Rata Value}

Delaware law purports to reject minority discounts under the so-called pro rata value doctrine, which looks to become the leading judicial rationale for rejecting discounts in and out of Delaware. ${ }^{48}$ In Delaware, the pro rata value doctrine was laid down in the 1989 appraisal case of Cavalier Oil Corp. v. Harnett. ${ }^{49}$

In Cavalier Oil, the Delaware Supreme Court held that "application of a discount to a minority shareholder is contrary to the requirement that the company be viewed as a "going concern." "50 Affirming the Vice Chancellor in Cavalier Oil, the Delaware Supreme Court held that "the objective of a section 262 appraisal is 'to value the corporation itself, as distinguished from a specific fraction of its shares as they may exist in the hands of a particular shareholder." ${ }^{\text {"s1 }}$ Accordingly, the court held that the fair value of a share of stock is equal to a pro rata or "proportionate interest" in the value of the entire corporation as a "going concern,", 52 and that no minority dis-

of the likelihood of such developments. Notice, for example, the shocked tones of the commentary following the decision in Smith v. Van Gorkom, 488 A.2d 858 (Del. 1985). See, e.g., Daniel R. Fischel, The Business Judgment Rule and the Trans Union Case, 40 Bus. LAW. 1437, 1455 (1985) (describing Van Gorkom as "one of the worst decisions in the history of corporate law"); Leo Herzel et al., 'Smith' Brings Whip Down on Directors' Backs, LEGAL TMMES WASH., May 13, 1985, at 14 (describing the result as "dumbfounding"); see also ROBERTA ROMANO, THE GENIUS OF AMERICAN CORPORATE LAW (1993) (collecting event studies of the impact of corporate law developments on stock market prices).

48 See infra Appendix A (collecting minority discount cases).

49564 A.2d 1137 (Del. 1989).

50 Id. at 1145.

s1 Id. at 1144 (quoting Vice Chancellor Jacobs's Chancery Court opinion).

52 Id. The Cavalier Oil court claimed that it was following settled law, reasoning that because it was long established in Delaware that an appraisal properly involved determining the value of the corporation as a "going concern," an appraising court was barred from valuing particular shares in and of themselves. See id. at 1144-45 (citing Tri-Continental v. Battye, 74 A.2d 71, 72 (Del. 1950)). The rule requiring fair value to be determined on the basis of the value of the corporation as a "going concern" (first enunciated in Tri-Continental), however, arose in response to an entirely different argument. In Tri-Continental, the dissenting shareholder argued (and the trial court agreed) that the corporation should be valued by considering net asset (or liquidation) value, rather than solely considering its value as an ongoing business. See Tri-Continental, 74 A.2d at 75-76 (rejecting an argument that the appraised value should equal net asset value on the ground that the shares must reflect "economic reality" and that the "intrinsic value of [a] share in a going concern" reflects a discount from the net asset value). The Tri-Continental case, then, set forth the basis on which the corporation should be valued-on an ongoing basis, not an asset-by-asset basis. See $i d$. Once the value of the corporation is determined, however, nothing in Tri-Continental prevents a court from finding that some shares of a corporation were worth more than other shares. The issue in Cavalier Oil was not raised in Tri-Continental, nor did Tri-Continental compel the holding in Cavalier Oil. 
counts should be applied in valuing particular shares to adjust the pro rata value to reflect the value of minority shares. ${ }^{53}$

The Delaware pro rata value doctrine has a certain surface procedural appeal-by shifting fair value analysis away from the shares being valued and to the company that issued the shares, it appears to sidestep many difficult questions, such as those raised by discounts and premiums. Because it imposes a mandatory, blanket rule against discounts, the doctrine has the apparent merit of eliminating arguments about the size of an appropriate discount and the circumstances in which discounts should apply-because all discounts are forbidden, such arguments are moot. Not only is the doctrine inconsistent with the language of DGCL section $262,{ }^{54}$ but, Delaware courts have given the doctrine little or no policy foundation beyond superficial tidiness. ${ }^{55}$ As demonstrated by the subsequent attempts of the Delaware

53 In addition to Tri-Continental, the Cavalier Oil court cited Bell v. Kirby Lumber Corp., 413 A.2d 137 (Del. 1980), as support for its holding. See Cavalier Oil, 564 A.2d at 1144. The Kirby Lumber court's rejection of minority discounts, however, was implicit only, and did not set up a formal doctrine as did the Cavalier Oil court. Moreover, the Kirby Lumber opinion reflects deference to the trier of fact throughout-a "hands off" attitude that could just as easily have accepted discounts as rejected them. Finally, Kirby Lumber was decided under the Delaware block method, prior to Weinberger v. UOP, Inc., 457 A.2d 701, 711-12 (Del. 1983), which substantially revised the Delaware law on fair value. See supra notes 44-45 and accompanying text. For that reason alone, the Cavalier Oil court had the opportunity to reevaluate its prior decisions regarding discounts.

54 DGCL section 262 does not, as one would expect from reading Cavalier Oil, direct a court to appraise the corporation, or even to appraise the dissenting shares on the basis of the value of the corporation. Rather, it directs the court to "appraise the shares, determining their fair value." DEL. CODE ANN. tit. 8, § 262(h) (1991) (emphasis added). This has been true since the DGCL was adopted in 1899. See 21 Del. Laws 273, $\$ 56$ (1899) (requiring the appraisal of the "value of the stock" held by the dissenting shareholders). Throughout DGCL section 262, the phrase "the shares" is repeated. Nowhere does DGCL section 262 make reference to the fair value of the corporation, "pro rata value," or "proportionate" value. If anything, the language of DGCL section 262 supports a valuation methodology that carefully discriminates among different shares, rather than ignoring those differences. Cf. 2 PRINCIPLES OF CORPORATE GOVERNANCE: ANALYSIS AND RECOMMENDATIONS § 7.22(a) (1992) (providing expressly that an appraisal should value stock as a "proportionate interest in the corporation, without any discount for minority status"). On the other hand, the "shares" language in DGCL section 262 may simply reflect a tacit but mistaken legislative assumption that the value of shares and the value of the corporation are equal, namely, that discounts do not exist.

55 Beyond simply enunciating the pro rata value doctrine, the Cavalier Oil court gave three reasons for not applying a minority discount: (1) doing so penalizes minority shareholders for lack of control, (2) doing so "unfairly enriches the majority shareholders who may reap a windfall ... by cashing out a dissenting shareholder," and (3) doing so risks injecting undue "speculation" into the appraisal process. Cavalier Oil, 564 A.2d at 1145. None of these reasons, however, provide significant support for the pro rata value doctrine. The first two reasons are conclusory and can be restated with equal force to support discounts. See infra note 257 (discussing the application of "fairness" arguments to discounts). The third reason is a procedural rationale for rejecting discounts, and is critiqued in Part IV.F, infra. Whether or not procedural concerns about speculation and the lack of "objective market data" provide a 
courts to apply Cavalier $\mathrm{Oil}^{56}$ the doctrine is indeterminate and unclear. ${ }^{57}$ As a result of this indeterminacy, courts have erratically applied discounts in some cases, leaving practitioners and investors with little guidance on whether and when minority discounts will be applied.

\section{Shareholder Level Discounts and Corporate Level Discounts}

In Covalier Oil, the corporate defendant noted that the appraising court in Tri-Continental, an earlier Delaware case, had calculated the net asset value ("NAV") of the corporation, which was a leveraged, closed-end investment company, and then discounted it by a percentage, reflecting the historical market-to-net-asset-value discount, in order to arrive at the fair value. ${ }^{58}$ The Cavalier Oil court distinguished the discount approved in TriContinental as being a "corporate-level" discount, unlike the "shareholderlevel" discount proposed by the corporation in Cavalier Oil..$^{59}$

The court held that shareholder-level discounts were unacceptable because they involve varying fair value based on the characteristics of the

good reason to accept or reject discounts, they still have no necessary link to the pro rata value doctrine. Similar concerns could be raised about "corporate level" adjustments, which the Delaware Supreme Court has viewed as acceptable under the pro rata value doctrine, see infra text accompanying notes 58-69 (explaining the court's differentiation between "corporate level" discounts in Tri-Continental and "shareholder level" discounts in Cavalier Oil), or, indeed, about many other elements of methodologies required by a fair value determination. In addition, the Covalier Oil court did not present any evidence regarding why such concens should be heavier in the context of "shareholder level" discounts.

56 See infra Part I.D.3.

57 In addition, the Cavalier Oil court did not address or even seem to be aware of contrary precedent upholding discounts based on the characteristics of the shares being valued. In Felder v. Anderson, Clayton \& Co., 159 A.2d 278 (Del. Ch. 1960), the.court accepted the court-appointed appraiser's reduction by $10 \%$ of an average price-earnings multiple for comparable companies "for certain reasons, such as the lack of marketability of the stock, etc." Id. at 285.

${ }^{58}$ See Cavalier Oil, 564 A.2d at 1144-45 (describing the Tri-Continental court's method of calculating fair value).

59 Id. This distinction was confirmed in a subsequent Delaware Supreme Court case, Rapid-American Corp. v. Harris, 603 A.2d 796 (Del. 1992). In that case, the trial court relied on the market prices of the minority shares of comparable companies in order to establish the value of various subsidiaries owned by Rapid-American, the company whose shares were being valued. The Delaware Supreme Court agreed that such prices "are discounted and do not reflect a control premium," and concluded that the trial court's valuation erroneously "treated Rapid as a minority shareholder in its wholly-owned subsidiaries" and so reversed. Id. at 804. The court cited Tri-Continental and Cavalier Oil as authority for the distinction between "shareholder level adjustments," which are impermissible under the pro rata value doctrine, and "corporate level" adjustments, which are necessary to "establish $\square$ the intrinsic value of the enterprise." Id. at 805-06. Because Rapid-American owned $100 \%$ of its subsidiaries, the court reasoned, it was unrealistic to value its subsidiaries at anything less than full firm value, including a company-level control premium. See id. 
shares "in the hands of a particular shareholder," rather than fixing fair value as a pro rata share of the firm value without reference to particular shares. Corporate level discounts, on the other hand, were acceptable because they were used to determine the value of the firm as a going concern. As we will see, however, this distinction is highly problematic.

It is true that the discounts in Tri-Continental and Cavalier Oil are facially distinguishable. The former discount was a reduction from the $\mathrm{NAV},{ }^{60}$ the latter was a reduction from a value derived by capitalizing earnings. $^{61}$ Thus, it is fair to say that, contrary to the argument of the corporation in Covalier Oil, ${ }^{62}$ the holding in Tri-Continental did not require the inclusion of a "shareholder-level" minority discount.

The two principal arguments used in Tri-Continental to justify including discounts at the "corporate level," however, also support inclusion of discounts in general. First, the Tri-Continental court reasoned that to exclude such a discount was "to fail to face the economic facts. ${ }^{.63}$ Second, the Tri-Continental court reasoned that "fair value" must equal what the shareholder "would have received ... one way or another as long as the company continued in business," and since a noncontrolling shareholder has no power to force liquidation, the only way for a shareholder to obtain value is "by the sale ... on the market," which will necessarily be at a discount. ${ }^{64}$ Both arguments closely resemble arguments used by courts outside Delaware to defend minority discounts in general. ${ }^{65}$ It is an "economic fact" that financial discounts exist, and it is a legal and practical fact that some shares have fewer rights (for example, to force liquidation) than other shares. Both ar-

${ }^{60}$ See Tri-Continental v. Battye, 74 A.2d 71, 75 (Del. 1950) ("The appraiser then arrived at the true or intrinsic value of a common share of General by applying the discount to the fair asset value of $\$ 5.44$, and arrived at a value of $\$ 4.08$ per share for the common stock of General.").

See Cavalier Oil, 564 A.2d at 1145-56 ("In order to arrive at a merger date valuation, [the expert witness] discounted back his terminal value and his projected net cash flow for the five year period.").

${ }^{62}$ See id. at 1144-45 (arguing that the Supreme Court of Delaware "recognized the appropriateness of discounting a dissenting shareholder's interest in an appraisal proceeding in Tri-Continental').

63 Tri-Continental, 74 A.2d at 76.
Id. at 76.

${ }^{65}$ See, e.g., Perlman v. Permonite Mfg. Co., 568 F. Supp. 222, 230-32 (N.D. Ind. 1983) (considering the fact that a plaintiff's shares represent a minority interest, that the shares lack marketability, and that the company is nondiverse in finding the fair market value of plaintiff's shares), affd, 734 F.2d 1283 (7th Cir. 1984); Armstrong v. Marathon Oil Co., 513 N.E.2d 776, 787-91 (Ohio 1987) (taking into account the willing-buyer/willing-seller price in addition to the stock market price in order to determine the fair value of the dissenting shareholder's stock); see also infra Part IV.E (discussing the relative merits of different discount rules). 
guments provide justifications for imposing a discount for lack of control, contrary to the holding in Cavalier Oil. ${ }^{66}$

In essence, the court in Tri-Continental equated fair value with market value, and because the market value of a noncontrol share will reflect a financial discount, such an equation imposes an implicit discount in arriving at fair value. It is irrelevant that this is done in the process of determining fair value (at the "corporate level"), and not after the value of the corporation as a "going concern" has already been determined (at the "shareholder level"). The fair value finally determined is lower than both the reference value from which the discount is taken and the value that would have been obtained had no such discount been imposed, and setting fair value equal to the lower value is only justifiable on grounds implicitly rejected in Cavalier Oil. In other words, the fact that the discount in Tri-Continental was imposed at the "corporate level" did not mean (as it seems at first glance) that all shares were valued equally, as pro rata claims on a single "going concern" value, as required by Cavalier Oil.

To see why, consider a closed-end investment company incorporated in Delaware with an NAV of $\$ 100$ and five shareholders, each holding one share of common stock. Assume that the company engages in four consecutive mergers; at each point, one shareholder dissents and perfects its appraisal rights, and the company's NAV remains the same, except for the effect of paying for a dissenting shareholder's shares. ${ }^{67}$ After the first shareholder dissents, each remaining shareholder holds a $25 \%$ stake; after the second dissents, each holds a $331 / 3 \%$ stake; after the third dissents, each holds a $50 \%$ stake; and, after the last transaction, one shareholder holds all of the outstanding shares. If the courts, following Tri-Continental, were to impose a "corporate-level" discount of $25 \%$ to the NAV in order to de-

${ }^{66}$ See Cavalier Oil, 564 A.2d at 1145 (rejecting minority discounts because they "impose[] a penalty for lack of control"). The "no-discount" rule required by the pro rata value doctrine is also at odds with Delaware law that permits the controlling shareholders to sell their control shares at a premium without sharing that premium with, or "taking along," other shareholders. See, e.g., Bershad v. Curtiss-Wright Corp., 535 A.2d 840, 844-45 (Del. 1987) (holding that the majority shareholder has no duty to sell its holdings merely because a sale would profit the minority shareholders).

67 This assumption is unrealistic because if the NAV remained unchanged after each merger, then it is hard to see why mergers would be undertaken. In addition, it is unlikely that four mergers would take place simultaneously; ordinarily, some change in the NAV would occur from normal market fluctuations over the time necessary to complete the merger. It seems realistic, however, to make equivalent assumptions: (1) with each merger, the shareholders continue to hold the same indirect proportionate interest in the pre-merger NAV because the new assets obtained balance out the cash paid (or shares issued) in each merger; and (2) the net present value of any change in the NAV from market fluctuations is either trivial or not systematically related to the mergers. 
termine the fair value in each appraisal, ${ }^{68}$ then the dissenting shareholders would receive the payments set forth in Table 1.

Table 1. Effect of Applying "Corporate Level" Discounts in Successive Appraisals

\begin{tabular}{|l|l|l|l|l|}
\hline & $\begin{array}{c}\text { Fair } \\
\text { Value of } \\
\text { Firm as a } \\
\text { Going } \\
\text { Concern }\end{array}$ & $\begin{array}{c}\text { Corporate } \\
\text { Level Discount }\end{array}$ & $\begin{array}{c}\text { Shareholders } \\
\text { Stake }\end{array}$ & $\begin{array}{c}\text { Pro Rata } \\
\text { Value }\end{array}$ \\
\hline Merger 1 & $\$ 100.00-$ & $25 \%=\$ 75.00$ & $\times 20 \%$ & $=\$ 15.00$ \\
\hline Merger 2 & $\$ 85.00-$ & $25 \%=\$ 63.75$ & $\times 25 \%$ & $=\$ 15.94$ \\
\hline Merger 3 & $\$ 69.06-$ & $25 \%=\$ 51.80$ & $\times 33 \%$ & $=\$ 17.27$ \\
\hline Merger 4 & $\$ 51.79-$ & $25 \%=\$ 38.84$ & $\times 50 \%$ & $=\$ 19.42$ \\
\hline Final NAV $\$ 32.37$ & & $\times 100 \%$ & $=\$ 32.37$ \\
\hline
\end{tabular}

Each successive dissenting shareholder receives an increasing payment for shares that (in theory, according to the pro rata value doctrine) represent identical pro rata claims on the firm's total value prior to the mergers. In other words, each shareholder's shares are valued differently, despite the fact that the corporation essentially remains unchanged. The final shareholder retains $100 \%$ of a company with an NAV of $\$ 32$, representing a premium of more than $100 \%$ above the $\$ 15$ received by the first dissenting shareholder. Even net of liquidation costs, the final shareholder could expect to derive a much higher value, compared to the dissenting shareholders, for the same initial pro rata share of the fair value of the same corporation. Yet the $\$ 75$ total fair value determined in the first appraisal implies that each share is worth $\$ 15$, the value awarded to the first dissenter. Because a controlling shareholder could obtain a higher per-share value by liquidating than by continuing as a going concern, the total firm value is actually equal to the NAV less the liquidation costs, something substantially above $\$ 75$.

The disparate treatment embedded in the "corporate-level" discount method used in Tri-Continental demonstrates not only that Cavalier Oil and Tri-Continental are at odds with one another, but, more importantly, that there is no substance to the pro rata value doctrine. If the pro rata value doctrine requires only that no discount be imposed at the "shareholder level," but permits a discount to be imposed at the "corporate level," then controlling shareholders seeking to obtain more than a pro rata share of the

68 This was the discount to the NAV that was applied in Tri-Continental. See TriContinental, 74 A.2d at 73. 
corporation's aggregate value only need to find some way to build in their discount at the stage of "corporate-level" valuation, as was done in TriContinental. Delaware courts since Cavalier Oil have realized belatedly that there are many ways to do this, and if a "no-discount" rule is to be taken seriously, then a stronger rationale is needed-one that focuses less on the "level" at which discounts are imposed and more on the working mechanics of the valuation methodologies employed and the sources of discounts, particularly on the existence or absence of control. ${ }^{69}$

${ }^{69}$ See infra Part I.D.2 (presenting methods by which to derive minority discounts and control premiums). The emptiness of the pro rata value doctrine is also illustrated by the issue of marketability discounts. See supra note 35 (explaining the rationale behind marketability discounts). Cavalier Oil and subsequent Delaware cases have held such discounts to be "shareholder level" discounts that are prohibited by the pro rata value doctrine. See Covalier Oil, 564 A.2d at 1144 (affirming the Vice Chancellor's rejection of a marketability discount); see also Hodas v. Spectrum Tech., Inc., C.A. No. 11265, 1992 WL 364682, at *4-5 (Del. Ch. Dec. 7, 1992) (rejecting a marketability discount); Pinson v. Campbell-Taggart, Inc., C.A. No. 7499, 1989 Del. Ch. LEXIS 50, at *48-50 (Nov. 8, 1989) (rejecting, without comment, discounted cash flow ("DCF") analyses to which both the dissenting shareholder's expert and the corporation's expert applied marketability discounts, and adopting a different valuation methodology). But cf. Hintmann v. Fred Weber, Inc., C.A. No. 12839, 1998 Del. Ch. LEXIS 26, at *9 (Feb. 17, 1998) (accepting a "small stock" premium in the calculation of the discount rate in a DCF analysis, despite its having the same effect and rationale as marketability discounts); Le Beau v. M.G. Bancorporation, Inc., C.A. No. 13414, 1998 WL 44993, at *10 (Del. Ch. Jan. 29, 1998) (same); Charlip v. Lear Siegler, Inc., C.A. No. 5178, 1984 Del. Ch. LEXIS 548 , at *11 (Nov. 27, 1984) (rejecting a marketability discount, not on the ground of the pro rata value doctrine, but because the litigants stipulated to the exclusion of any consideration of market value in determining fair value); Felder v. Anderson, Clayton \& Co., 159 A.2d 278, 284 (Del. Ch. 1960) (accepting a marketability discount).

By contrast, New York courts have reasoned that if all outstanding shares of a corporation are equally unmarketable, then it is natural to say that a discount to reflect that unmarketability is a "corporate-level" adjustment to the value of the firm itself, rather than a "shareholderlevel" adjustment to the value of the shares. Using this logic, New York courts have held that such discounts are "corporate-level" discounts that are consistent with the pro rata value doctrine. See Friedman v. Beway Realty Corp., 661 N.E.2d 972, 976 (N.Y. 1995) ("[C]ourts should determine the minority shareholder's proportionate interest in the going concern value of the corporation as a whole ...."). The difficulty with this logic, however, is that frequently some shares will be unrestricted and freely tradable, whereas others will be restricted and thus less marketable. For example, minority shares may be subject to buy/sell restrictions to which the controlling shareholder's shares are not. In such a case, it would be difficult to view marketability as a feature of the firm, rather than as a feature of the shares. Yet, it would be equally difficult to justify accepting a marketability discount in a case where no shares were freely transferable while rejecting such a discount where some shares were freely transferable. Such a result would seem to reward a controlling shareholder (or punish a minority shareholder) for a feature of the controlling shareholder's shares. In other words, the discount would, in a sense, be an adjustment at the "shareholder level," but perversely based on the features of shares not being valued. 


\section{Minority Discounts and Control Premiums}

In addition to producing an incoherent distinction between firm-level and shareholder-level discounts, the pro rata value doctrine has also left Delaware courts (and the practitioners reading their opinions) more than a little confused about whether or how to distinguish minority discounts from control premiums. ${ }^{70}$ In the process of resisting control premiums, some courts appear to have applied minority discounts unintentionally. As a result, Delaware courts may have underestimated fair value and unintentionally encouraged conflict transactions. Before reviewing the post-Cavalier Oil cases that demonstrate this confusion, it is helpful to explore what control premiums are and how they relate to minority discounts.

\section{a. Control Premiums}

In judicial fair value determinations, premiums generally are the converse of discounts - an adjustment upwards from a reference value to reflect a feature of the shares being valued or a feature of their holder. As with minority discounts, control premiums exist in the financial markets and represent the empirical difference between (1) prices that buyers are willing to pay for stock that will give a buyer control of a corporation ("control shares") and (2) prices that buyers are willing to pay for stock that does not convey control of the corporation ("minority shares")." It is said, for example, that Company X paid a "control premium" of $Y \%$ over market to acquire Company $Z$. The existence of control premiums is well known and well documented. Whether measured against very small blocks that trade

${ }^{70}$ See Barry M. Wertheimer, The Shareholders' Appraisal Remedy and How Courts Determine Fair Value, 47 DUKE L.J. 613, 648-49 (1998).

Unfortunately, the courts and litigants have confusingly phrased the issue in terms of whether the addition of a control premium is appropriate. This is unfortunate because the real question is not whether to add a control premium but is instead whether a market price based valuation should be adjusted upward to correct for the inherent minority discount reflected therein.

Id.

71 See, e.g., CORNELL, supra note 4, at 243 (discussing the application of control premiums in appraisals). Comell notes that

both research in finance and common sense support the proposition that a buyer is willing to pay more than the market price for a controlling interest in a company... when the buyer believes that the future cash flow of the company... can be increased once it is under his or her control.

Id.; see also PRATT ET AL., supra note 4, at 298-326 (collecting control premium data); 18A AM. JUR. 2D Corporations $\S 795$ (1985) ("II]t is generally recognized that majority stock is more valuable than minority stock."). 
on the public stock markets daily or against larger but noncontrol share blocks, control shares command premium prices. ${ }^{72}$

Control premiums can be attributed to a number of sources which vary depending on the acquiror, the target, the quality of the target's management, the reasons for the acquisition, the financial and legal structure of the acquisition, and general economic and legal factors. ${ }^{73}$ For discussion, three sources of control premiums will be identified: ${ }^{74}$ (2) expropriation value, and (3) pure control value. ${ }^{76}$

(1) synergy value, ${ }^{75}$

72 For the period from 1981 through 1994, data from the Mergerstat Review show that the prices paid in acquisitions by negotiated purchase or tender offer of control shares in public companies exceeded the market prices for the targets' outstanding stock by an average of approximately $38 \%$. During the same period, average prices paid in the same types of acquisitions of large ( $>10 \%$ ) but noncontrolling blocks of shares in public companies also exceeded market prices for the targets' outstanding stock, but premiums for these noncontrol share blocks averaged only $34.5 \%$. See MERGERSTAT REVIEW 1997, supra note 13 (providing a year-by-year comparison of the average premiums offered over the market price); see also PRATT ET AL., supra note 4, at 316-19 (noting studies showing the existence of median control premiums ranging from $28 \%$ to $35 \%$ ); Gary Fodor \& Edward Mazza, Business Valuation Fundamentals for Planners, 5 J. Fin. PLAN. 170, 177 (1992) (stating that control premiums paid for public companies averaged $30 \%$ to $40 \%$ from the late 1960 s to the late $1980 \mathrm{~s}$ ).

${ }^{73}$ See Mendel v. Carroll, 651 A.2d 297, 305 (Del. Ch. 1994).

Optimists see the control premium as a reflection of the efficiency enhancing changes that the buyer of control is planning on making to the organization. Others tend to see it, at least sometimes, as the price that a prospective wrongdoer is willing to pay in order to put himself in the position to exploit vulnerable others, or simply as a function of a downward sloping demand curve demonstrating investors' heterogeneous beliefs about the subject stock's value.

Id. (citations omitted); see also RONALD J. GILSON \& BERNARD S. BLACK, THE LAW AND FINANCE OF CORPORATE ACQUISTIONS 255-498 ( $2 \mathrm{~d}$ ed. 1995) (giving reasons for the existence of control premiums); PRATT ET AL., supra note 4, at 301-10 (noting the prerogatives of control and ways in which the rights of the controlling shareholders of different corporations may vary, causing the control premiums to vary in size); Shishido, supra note 37 , at 86-90 (giving reasons for the existence of control premiums).

74 The discussion in this Article focuses on the possible sources of control premiums that are consistent with the semi-strong form of the efficient market hypothesis. Control premiums also have been attributed to market failures. See, e.g., Reinier Kraakman, Taking Discounts Seriously: The Implications of "Discounted" Share Prices as an Acquisition Motive, 88 ColUM. L. REV. 891, 897-98 (1988) (discussing the misinvestment hypothesis in the context of market discounts); see also Lynn A. Stout, Are Takeover Premiums Really Premiums? Market Price, Fair Value, and Corporate Law, 99 YALE L.J. 1235, 1244-52 (1990) (arguing that investors heterogeneously value given shares and that this explains tender offer premiums)

See PRATT ET AL., supra note 4, at 300 (analyzing control premiums separately from synergy value, and referring to the control premium plus the synergy value as an "acquisition premium"). In my experience, control premiums more commonly are thought to include synergy value; therefore, I do not adopt that terminology, but instead identify synergy value as a distinct element of the control premium.

${ }^{76}$ As a negative offset to these sources of value, control persons that own less than $100 \%$ of a company must deal with the costs associated with controlling a company with outside 
Synergy value arises when two assets are more valuable in combination than in isolation or, put otherwise, when two assets are more valuable when controlled by the same firm than when controlled by different firms. Synergies can arise on the input and output sides of a firm: input synergies reduce costs associated with production without causing a proportionate reduction in revenues; output synergies increase revenues without causing a proportionate increase in costs. The combination of two firms that control synergistic assets permits the realization of synergy value.

Expropriation value arises from the ability to expropriate wealth from minority shareholders through fraud, theft, or breach of fiduciary duties, such as freeze-outs at a clearly unfair price or payment of excessive compensation. ${ }^{77}$ Expropriation value also arises in "gray areas" where behavior that is currently permitted, or at least tolerated, likely would be condemned if it could be policed costlessly. Some examples of such behavior are the excessive retention of assets; ${ }^{78}$ excessive distributions; ${ }^{79}$ payment of above-

investors ("public company costs"). Public company costs include the significant costs imposed by regulation, such as SEC filings, shareholder reports, shareholder meetings, and inspection of records and appraisal rights. Public company costs also include the risk of litigation (such as "entire faimess" litigation), negative press relations, and "activism" (such as proposals under SEC Rule 14a-8) from disgruntled minority shareholders. See Harry DeAngelo et al., Going Private: Minority Freezeouts and Stockholder Wealth, 27 J.L. \& EcoN. 367, 371-74 (1984). Such costs do not rise proportionately with corporate assets or equity, and thus, as a corporation grows in size, they become increasingly less important relative to the other sources of value.

77 Expropriation value may be attributed to agency costs: the inability of the principal (shareholders or minority shareholders) to observe perfectly the behavior of the agents (managers or controlling shareholders) creates the risk that the agent will not act in the interest of (all) shareholders. See Kenneth J. Arrow, The Economics of Agency, in PRINCIPALS AND AGENTS: THE STRUCTURE OF BUSINESS 37, 38-39 (John W. Pratt \& Richard J. Zeckhauser eds., 1991) (discussing the principal-agent problem of hidden action). Professor Coffee also has distinguished expropriation value from synergy value in the context of the sale of control by controlling shareholders. See John C. Coffee, Jr., Transfers of Control and the Quest for Efficiency: Can Delaware Law Encourage Efficient Transactions While Chilling Inefficient Ones?, 21 DEL. J. CORP. L. 359, 412-20 (1996) (discussing "synergy gains" as distinct from "misappropriated business opportunities").

${ }_{78}$ See Shishido, supra note 37, at 86-90 (noting that the retention of assets may not maximize firm value because expected discounted cash flows from those assets are less than their liquidation value due to internal factors such as poor management or to external factors such as high inflation). But $c f . i d$. (noting that the controlling shareholders may nevertheless choose to retain such assets due to (1) the love of position and perquisites, (2) the reluctance to harm the employees, or (3) the hope that the minority will seek to sell out prior to liquidation, thereby increasing returns to the controlling shareholder).

79 Firm value would be lowered if the discounted value of cash in the firm's hands exceeded the expected return on cash paid out in the hands of shareholders; yet, control persons might make such distributions to provide a control person with liquidity. $C f$. PRATT ET AL., supra note 4, at 301-02 (listing the power to pay dividends as one of the powers of control, and noting that minority shareholders have no assurance as to liquidity). 
market, but not clearly excessive, amounts for goods or services; or freezeouts priced to take advantage of a "blockage" of non-material information. Absent perfect enforcement mechanisms, all of these items potentially work for a controlling shareholder; control shares are worth more than minority shares, in part, because they put controlling shareholders in a position to exploit imperfect policing mechanisms. ${ }^{81}$

Expropriation value arises whether or not a control person intends to engage in such behavior. For example, control person $A$, who is willing to break the law, will value control shares $\$(X+Y)$ more than minority shares, where $\$ X$ is the value arising from the fact that no other control person can

${ }^{80}$ As Victor Brudney notes, some element of expropriation value relates to the risk of "systematic impediments to the flow of information to the market." Victor Brudney, Efficient Markets and Fair Values in Parent Subsidiary Mergers, 4 J. CORP. L. 63, 71 (1978). A control person may cause blockages or distortions of information about a subsidiary in both a lawful and an unlawful manner. Examples of simple, unlawful informational blockages are the nondisclosure of material information required to be disclosed in periodic reports under the Securities Exchange Act of 1934 or misleading disclosure in violation of Rule 10b-5. Examples of lawful blockages include the choice of accounting conventions and the failure to provide adequate "color" to permit a full understanding of mandatory disclosures where the failure does not rise to the level of a demonstrable omission of a material fact necessary to make the disclosed facts not misleading. It may be argued that the latter types of informational blockages are unlawful precisely to the extent that market values would be affected by the blockages. In practice, however, many types of informational blockages that do not rise to the level of "materiality" nevertheless affect market prices. See Cede \& Co. v. Technicolor, Inc., 542 A.2d 1182, $1187 \mathrm{n} .8$ (Del. 1988) ("[W] recognize that the majority may have insight into their company's future based primarily on bits and pieces of nonmaterial information that have value as a totality."); ROBERT CHARLES CLARK, CORPORATE LAW 507 (1986) (discussing the harm that occurs when information lawfully not communicated to the market affects stock prices).

This, it should be noted, is not an argument that the efficient (capital) market hypothesis ("EMH") is incorrect (in the semi-strong or weak versions), see infra notes 177-84 and accompanying text (discussing the EMH), because market prices may still, arguendo, rapidly reflect all public information. Rather, it is an argument that, in practice, the existence and enforcement of the securities laws do not reliably cause control persons to disclose publicly all information that would, if disclosed publicly, influence market prices.

Accounting rules also give managers considerable discretion as to the timing and content of accounting charges and recognitions. Studies of accounting data suggest that firms use that discretion to "manage" earnings as a routine part of business. See Michael Kinney \& Robert Trezevant, The Use of Special Items to Manage Earnings and Perceptions, J. FIN. STATEMENT ANALYSIS, Fall 1997, at 45, 45-48; Letter from Lynn Turner, Office of the Chief Accountant of the Securities and Exchange Commission, to Thomas Ray, Director, Audit and Attest Standards, American Institute of Certified Public Accountants 1-2 (Oct. 9, 1998) (on file with author) (regarding auditing and financial reporting concerns, noting the "trend" towards "inappropriate management of earnings," and describing in detail the "troublesome areas involving the use of inappropriate earnings management techniques").

81 As noted in Part IV, infra, few empirical studies have attempted to measure the size of expropriation value standing alone. For one such study, see infra note 93 and accompanying text (discussing the difference). Cf. Barclay \& Holderness, supra note 36, at 371 (exploring the relationship between expropriation value and minority discounts). 
expropriate value from the firm and $\$ Y$ is the value arising from A's expectation of expropriating value from the firm. But, even control person $B$, who is unwilling to break the law, will value the control shares $\$ X$ more than $B$ values the minority shares.

Pure control value is whatever residual value may attach to management, including such things as the certainty of being able to direct operations, obtain further (potential) synergies, freeze out the minority shareholders, and choose the time for payouts through dividends, liquidation, or recapitalization. Managerial control has value-over and above expropriation value and synergy value-because it stands on reserve for a control person as a tool. ${ }^{82}$ That quality of standing reserve has value just as an option on stock has value, and just as options can have substantial value even when "out of the money," pure control value may be considerably higher than intuition would suggest. ${ }^{83}$

Every observed control premium will not reflect all of these items. For example, some transactions may not be expected to give rise to synergies. If the minority shareholders are eliminated entirely, then the expropriation value will disappear and the deal price will not reflect future opportunities (although if the deal price is based on historical minority share prices, then it will reflect past expropriation value to that extent). Finally, observed control premiums will-like any market price-reflect mistakes in practice. "Buyers' hubris," the "winner's curse," and "unchecked managerialism" have all been identified as potential sources for control premiums in mergers and acquisitions. ${ }^{84}$ Nevertheless, a given control premium at least should be analyzed initially as reflecting each of these types of value.

${ }^{82}$ See Sugato Bhattacharyya \& Rajdeep Singh, The Allocation of Residual Rights 2 (Dec. 5,1995 ) <http://www.ssm.com/papers/9812/98122613.pdf> (noting that the right to design the procedure for the sale of a firm "has value ... over and above the rights to cash flows arising from the sale" (emphasis omitted)); $c f$. Randall Morck et al., Management Ownership and Market Valuation, 20 J. FIN. ECON. 293, 294-95 (1988) (stating that "[w]ith effective control, the manager may indulge his preference for non-value-maximizing behavior," and finding that Tobin's $Q$, a proxy for market valuation of the firm's assets, rises as board ownership rises between $0 \%$ and $5 \%$, falls as ownership further rises between $5 \%$ and $25 \%$, and then rises more slowly above 25\%); Karen Hopper Wruck, Equity Ownership Concentration and Firm Value: Evidence from Private Equity Financings, 23 J. FIN. ECON. 3, 23-24 (1989) (analyzing data suggesting that stock prices of publicly held firms decline as a controlling block is assembled). See generally RICHARD A. BREALEY \& STEWART C. MYERS, PRINCIPLES OF CORPORATE FINANCE 589-616 (5th ed. 1996) (discussing option pricing theory).

83 See Bebchuk \& Kahan, supra note 43, at 5.

84 See RICHARD THALER, THE WINNER's CURSE 50-62 (1992) (explaining the concept of the "winner's curse"); Bernard S. Black, Bidder Overpayment in Takeovers, 41 STAN. L. REV. $597,624-26$ (1989) (discussing managers' effects on the valuation of stock prices). 


\section{b. Relationship Between Discounts and Premiums}

The term "minority discount" is generally used to mean the difference between the value of control shares and the value of a minority share of a public company. ${ }^{85}$ According to this usage, "minority discounts" and "control premiums" are simply the inverse of one another. ${ }^{86}$ Both legal discounts and discounts in the financial markets are likely to be larger if the public company has a control person. Ceteris paribus, ${ }^{87}$ the presence of a control person will reduce the value of publicly held minority shares ${ }^{88}$ because (1) control persons increase the risk of expropriation ${ }^{89}$ and (2) control

85 See Rapid-American Corp. v. Harris, 603 A.2d 796, 806 (Del. 1992) ("The exclusion of a 'control premium' artificially and unrealistically treated Rapid as a minority shareholder."); Armstrong v. Marathon Oil Co., 513 N.E.2d 776, 790 (Ohio 1987) (permitting the application of a minority discount on the ground that " [ $[$ ] $]$ he purchase of stock to gain controlling interests is not properly includable in determining the market value of the shares of stock"' (quoting Foglesong v. Thurston Nat'l Life Ins. Co., 55 P.2d 606, 611 (Okla. 1976))); see also CORNELL, supra note 4, at 239 (referring to minority discounts as the "flip side" of control premiums); Calio, supra note 33, at 23 (stating that minority shareholders are entitled to a pro rata share of a control premium in an appraisal proceeding); Bate C. Toms, III, Compensating Shareholders Frozen Out in Two-Step Mergers, 78 ColUM. L. REV. 548, 562 (1978) (noting that "the purchase price [that a noncontrolling shareholder] originally pays should be at a discount relative to the price of the controlling shares, a discount reflecting the value of control').

86 In percentages, the relationship between a control premium and a minority discount, if each measures the same thing, is expressed as $D=1-[1 /(1+P)]$, where $P$ is the premium and $D$ is the related discount. Thus, a reference value of $\$ 10$ would be increased by a $50 \%$ premium (\$5) to produce a control share value of $\$ 15$; the control share value of $\$ 15$ would be decreased by a discount of $1-(1 / 1.5)$, or $.33 \%(\$ 5)$ to produce a minority share value of $\$ 10$.

87 Of course, all things may not be equal. The presence of a controlling shareholder may improve managerial monitoring and thus reduce the expropriation value relative to a firm without a controlling shareholder. In other words, slack may be reduced even if looting is more common. I thank Mike Fitts for this point. In addition, the incentives for controlling shareholders to loot a subsidiary are lower than the risk of managers looting an uncontrolled public company, holding constant the likelihood that such looting would be discovered and punished because controlling shareholders would be looting from themselves to the extent of their investment in the subsidiary. See Morck et al., supra note 82, at 311-14 (interpreting empirical results to suggest that a controlling shareholder has dual effects).

${ }^{88}$ See Lawrence Hamermesh, Analysis of Kleinwort Benson Ltd. v. Silgan Corp., 14 BANK \& CORP. GOVERNANCE L. REP. 862, 862 (1995) (discussing Professor Lawrence Hamermesh's analysis of Kleinwort Benson Ltd. v. Silgan Corp. as a "significant step forward in substantive valuation analysis"); Alexander Khutorsky, Note, Coming in from the Cold: Reforming Shareholders' Appraisal Rights in Freeze-Out Transactions, 1997 COLUM. Bus. L. REV. 133, 160 n.169 (1997) ("The theoretical existence of a control premium suggests that [the] price of minority shares held in a company controlled by a majority shareholder should be lower than the price of shares held in the same company but with a more dispersed ownership structure."). For an empirical study demonstrating this effect, see Wruck, supra note 82, at 20 , discussing the effect of purchaser control on share value.

89 See Brudney, supra note 80, at 69-71 (discussing why the stock of a subsidiary with a control person will sell at a discount relative to the price at which the stock would sell if there were no controlling person). 
persons reduce the potential of a third-party sale of all of the shares at a control premium ("third-party sale potential"). ${ }^{90}$ Still, whether or not a control person exists, if the "minority discount" is analyzed simply to be the inverse of a "control premium," then a court will have three choices in determining fair value: (1) it can include a control premium, (2) it can include a minority discount, or (3) it can split the difference and include some of each.

Minority discounts and control premiums may, however, be distinguished. ${ }^{91}$ For example, "minority discount" may be used to mean the difference between control share value and synergy value (and/or pure control value) on the one hand, and minority share value, on the other hand. ${ }^{92}$ De-

[T] he shadow cast by the overhang of the parent's control on the current market value of the subsidiary's shares ... may be a function merely of the inability of new groups to acquire control on the market, but ... may also be a function of the likelihood of exploitation such as an unfair merger, which would be too costly for disarrayed minority stockholders to challenge.

Victor Brudney \& Marvin A. Chirelstein, Fair Shares in Corporate Mergers and Takeovers, 88 HARV. L. REV. 297, 306 (1974).

${ }^{90}$ See Chazen, supra note 33, at 1466-77 (discussing the impact that a statement by a control person concerning her unwillingness to sell control shares to a third party would have on the value of the minority shares). Third-party sale potential, commonly referred to as "market fluff" or "takeover speculation," has become a significant factor potentially affecting market prices in the wake of the large number of high-premium merger and acquisition transactions during the 1980s. Despite the relative fall off in $M$ \& A activity during the early 1990 s, expectations that high-premium M \& A activity would resume appear to have been a factor buoying stock prices during that period. These expectations have proven to be reasonable with the reemergence of M \& A activity in the mid-1990s. See Geoffrey Colvin, The Year of the Megamerger, FORTUNE, Jan. 11, 1999, at 62, 63 (noting that " 1998 was the biggest year ever for takeovers"). Agency costs associated with the relationship between the managers and the shareholders of a noncontrolled public company would not be expected to reduce the third-party sale potential as much as would the agency costs associated with the presence of a controlling shareholder, because MBOs trigger auction duties under Revlon, Inc. v. MacAndrews \& Forbes Holdings, Inc., 506 A.2d 173 (Del. 1986). "Market forces must be allowed to operate freely to bring ... the best price available." Id. at 184 . A controlling shareholder, however, has no obligation to sell the controlled company to a third party, even if the controlling shareholder sells the control stake, see Bershad v. Curtiss-Wright Corp., 535 A.2d 840, 845 (Del. 1987) ("Clearly, a stockholder is under no duty to sell its holdings in a corporation, even if it is a majority shareholder."), and even if the third party would pay a higher price, see Mendel v. Carroll, 651 A.2d 297, 306 (Del. Ch. 1994) ("[T] he fact that [a third party] was willing to pay more for all of the shares does not [mean the first] proposal was not fair.").

${ }^{91}$ See Coffee, supra note 77, at 412-20 (arguing for such a distinction in the context of sales of control by controlling shareholders).

92 This type of discount seems to be what is referred to in the recent Delaware Chancery opinion in Kleinwort Benson Ltd. v. Silgan Corp., Civ. A. No. 11107, 1995 WL 376911, at *3 (Del. Ch. June 15, 1995) (quoting the corporation's valuation expert as stating that "'the preponderance of opinion is that there is some minority interest that's implicit in a publicly traded company's price" in addition to the portion of the control premium that reflects "potential synergies"'). This type of discount also appears to be the usage adapted by Pratt. See 
fined this way, "minority discount" represents the depressive effect of expropriation value, but excludes any synergy value attributable to a particular transaction and/or whatever value arises from having control in itself. Such discounts are difficult to observe directly, because determining such a discount requires deducting (or adding) values that do not reflect public market transactions ${ }^{93}$ - that is, such discounts require estimating the synergy value, pure control value, or expropriation value-none of which, in isolation, is easy to observe directly.

\section{Post-Cavalier Oil Case Law}

A review of post-Cavalier Oil cases demonstrates two sets of problems caused by Delaware's pro rata value doctrine. First, courts have failed to recognize implicit discounts as such, and so have accepted them, even while purporting to adhere to the pro rata value doctrine (the "implicit discount mistake"). ${ }^{94}$ Second, courts have failed to distinguish between discounts and premiums: three courts rejected "premiums" and imposed discounts, notwithstanding Cavalier Oil $;{ }^{95}$ one court accepted a premium to eliminate a minority discount (the "equivalency mistake"). ${ }^{96}$ Only two Delaware courts have perceived that control premiums and minority discounts can be distinguished. ${ }^{97}$

PRATT ET AL., supra note 4, at 300-23 (distinguishing control premiums, which exclude synergy value, from acquisitions premiums, which include synergy value, and equating control premiums to minority discounts).

93 A recent study attempts to estimate this sort of discount by examining the relationships between controlled subsidiary accounting values and parent and subsidiary market values. The study concludes that shares in such subsidiaries are valued by the minority investors relative to the parent companies at a discount ranging from $13 \%$ (based on subsidiary asset values) to $33 \%$ (based on subsidiary earnings), an analysis that should exclude the synergy values but would include the pure control value. See generally Roger C. Graham, Jr. \& Craig E. Lefanowicz, Valuation of Companies for the Estate and Gift Tax: Evidence of Minority Interest Discounts, ADVANCES IN TAX'N (forthcoming) (describing a study that examines the relative values of controlling and noncontrolling interests in parent-subsidy corporate pairs). In any event, the existence of such discounts seems to be certain, based on the fact that policing mechanisms for expropriation do not work perfectly.

94 See infra notes 98,103,108, 110 and accompanying text (noting that the implicit discount reflects expropriation value, lack of synergy value, and pure control value).

95 See infra notes 100, 108-10 and accompanying text (noting that the courts rejected premiums in Salomon Bros. Inc. v. Interstate Bakeries Corp., Smith v. Shell Petroleum Inc., and In re Radiology Associates, Inc. Litigation).

96 See infra text accompanying notes 111-12 (discussing the inclusion of a $30 \%$ "control premium" by the court in Hodas v. Spectrum Technology, Inc. to adjust for a minority discount).

97 See infra note 118 and accompanying text (suggesting that in addition to minority discounts, control premiums might include synergy value). 
a. Smith v. Shell Petroleum, Inc. and In re Appraisal of Shell Oil Co.

The appraisal case arising out of Royal Dutch Petroleum's freeze-out of Shell Oil Company illustrates both of these mistakes. Shell Oil had been $70 \%$ owned by Royal Dutch Petroleum since the 1920 s, with the remaining $30 \%$ held by the public. In January 1984, with Shell's public shares trading at $\$ 44,{ }^{98}$ Royal Dutch announced its plan to freeze out the minority shareholders at $\$ 55$. After independent Shell directors rejected the $\$ 55$ price and made a counteroffer of $\$ 75$, Shell shares traded up to $\$ 58$. Royal Dutch terminated discussions with Shell, and commenced a tender offer at $\$ 55$, which it subsequently increased to $\$ 58$. Shell shares traded up to $\$ 60$.

In June 1984, Royal Dutch and a class of minority shareholders settled fiduciary duty claims for an increase of $\$ 2$ for all of the tendering shareholders and all of the shareholders who waived their appraisal rights in a second-step freeze-out. Royal Dutch obtained $95 \%$ of the outstanding Shell shares in the tender offer, and in June 1985, after a year of further litigation, the freeze-out was closed, and Royal Dutch obtained $100 \%$ of Shell's stock.

A number of shareholders dissented and sought to have their shares appraised under DGCL section 262. In December 1990, the Delaware Chancery Court delivered its appraisal opinion ${ }^{99}$ and made two findings relevant to premiums and discounts. It first held that the dissenting shareholders were not entitled to a control premium. The dissenters' "basic premise that ... stockholders are entitled to a premium," the Shell court wrote, was flawed. ${ }^{100}$ The court cited Cavalier Oil, indicating its belief that the pro rata

98 All prices are per-share amounts; all facts are from Smith $v$. Shell Petroleum, Inc., Civ. A. No. 8395, 1990 WL 84218 (Del. Ch. June 19, 1990), stating that the proposed merger minority shares would be cashed out at $\$ 55$ per share, and In re Appraisal of Shell Oil Co., Civ A. No. 8080, 1990 WL 201390 (Del. Ch. Dec. 11, 1990), affd, 607 A.2d 1213 (Del. 1992), stating that shareholders were cashed out at $\$ 58$ per share prior to the merger.

99 See In re Appraisal of Shell Oil, 1990 WL 201390, at *1. In the appraisal case, Royal Dutch argued that the fair value of the Shell shares was $\$ 55$ per share; dissenting shareholders argued for $\$ 89$ per share. After noting that all of the methodologies proposed by the parties were flawed, the court accepted one of the shareholders' methodologies as the most reasonable and adjusted it down by an arbitrary $20 \%$ to arrive at a fair value of $\$ 71.20$, which the court candidly noted, was "between" the parties' proposed values-in fact, it almost exactly split the difference. See id. at *34-35 (discussing how the court arrived at a fair value of $\$ 71.20$ per share).

${ }_{100}$ Id. at *16. In re Appraisal of Shell Oil did not discuss at length the first post-Cavalier Oil fair value case that applied the pro rata value doctrine-the appraisal opinion in Cede \& Co. v. Technicolor, Inc., Civ. A. No. 7129, 1990 WL 161084 (Del. Ch. Oct. 19, 1990), where the court found that DGCL section 262(h) barred valuation relating to the business plans of an acquiror. See Technicolor, 1990 WL 161084, at *20 ("[V]alue added to the corporation by the implementation... of [the acquiror's] new business plan for the company is not value to which, in an appraisal action, petitioner is entitled to a pro rata share ...."). The dissenting shareholders in Technicolor argued that Weinberger $v$. UOP had construed the exclusion in 
value doctrine prohibited any upward adjustment at the shareholder level of the corporation's value or any premium on the corporation's value.

In striking contrast, however, the court then approved a "limited options" discount proposed by Royal Dutch on the theory that minority shareholders have "limited options" available for realizing value for their shares since they lack control. ${ }^{101}$ The court reasoned that absent a merger proposal, " the trading price is a more realistic alternative for the shareholders than a liquidation value or a merger market value." ${ }^{102}$ Because minority-

DGCL section 262 of merger-related value to exclude only the "speculative" value arising from a transaction, but the Technicolor court rejected this as contrary to (1) the plain language of the statute and (2) the "basic concept of value under [\$262] ... that the stockholder is entitled to be paid for that which has been taken from him." Id. at *19 (quoting Tri-Continental Corp. v. Battye, 74 A.2d 71, 72 (Del. 1950)). "Future value that would not exist but for the merger cannot... be said to have been taken from a dissenting shareholder ..., even if ... capable of being proven ...."Id. Subsequently, the Delaware Supreme Court overturned the Chancery Court opinion in Technicolor as inconsistent with Weinberger. See Cede \& Co. v. Technicolor, Inc., 684 A.2d 289, 296-301 (Del. 1996) (asserting that synergies must be included in "fair value" if, during the period between the tender offer and the freeze-out merger in a two-step takeover, the acquiror takes sufficient steps so that the synergies are known and not speculative and are part of the company being valued).

Nor did In re Appraisal of Shell Oil cite earlier Delaware opinions that could be read to support the exclusion of a control premium. In Sterling v. Mayflower Hotel Corp., 93 A.2d 107, 111 (Del. 1952) and Sporborg v. City Specialty Stores, Inc., 123 A.2d 121, 124 (Del. Ch. 1956), the courts refused to consider the market prices to be distorted by the impact of an acquiror's purchases at a control premium, and the cases may be read as refusing to consider the market prices where they may reflect the synergy value arising from the appraisal-triggering transaction itself. In a subsequent case, In re Olivetti Underwood Corp., 246 A.2d 800, 80405 (Del. Ch. 1968), the court adjusted the market prices downward to eliminate the impact of such premium purchases, but also refused to consider post-acquisition market prices because of the acquiror's announced intention to freeze out the remaining public shares. See Theodore N. Mirvis, Two-Tier Pricing: Some Appraisal and "Entire Fairness" Valuation Issues, 38 BUS. LAw. 485, 490-95 (1983) (discussing pre-Weinberger Delaware case law regarding control premiums).

101 See In re Appraisal of Shell Oil, 1990 WL 201390, at *31 (considering the "realistic alternatives" available to the stockholders and noting that a sale or liquidation of Shell was unlikely).

${ }^{102}$ Id. (quoting an argument made on behalf of Royal Dutch). The court rejected the trading (or unaffected market) price of $\$ 44$ proposed by Royal Dutch-not as an impermissible form of discount, but on the ground that Royal Dutch's expert had begun with an artificially low $\$ 40$ market price from 30 days prior to the merger announcement and did not adjust it sufficiently to reflect the substantial rise in the price of oil stocks. See id. at *29-30 (explaining Royal Dutch's methodology, and noting that the result was "illogical" since the proposed $\$ 44$ price represented "a zero percent change from the $\$ 44$ per share closing price ... one day prior to the ... merger announcement ..., not withstanding a substantial rise in the market price of oil stocks over the relevant period"). The court asserted that the use of the stock price 30 days prior to the merger announcement was not necessarily unlawful, but that given the circumstances of the case, it appeared to be an attempt to lower the valuation. See id. at *29 (noting that the use of the "stock price 30 days prior to the merger announcement ... was not improper, as a matter of law"). The clear implication of the opinion is that if Royal Dutch had started with a pre-announcement market price of $\$ 44$ and increased it suffi- 
share market prices generally reflect an implicit minority. discount, ${ }^{103}$ the Court of Chancery accepted a minority discount-contrary to the decision in Cavalier Oil.

Shell did attempt to distinguish its "limited options discount" from the "minority discount" rejected in Cavalier Oil. The fair value proposed by Morgan Stanley (Royal Dutch's valuation expert) and accepted in Shell was derived "by balancing... liquidation, merger market and trading value analyses [in a way that recognized that] it was unlikely that there would be a sale or liquidation of Shell." "104 In other words, the discount was an implicit "corporate level" adjustment, rather than an explicit "shareholder level" adjustment, and was balanced with values that did not reflect the adjustment so that the ultimate impact of the discount on fair value was mitigated. To the extent that fair value reflects such a discount, however, it will be lower than it would be without it, regardless of whether the discount is implicit or explicit, shareholder-level or company-level. As the court asserted: " $R e c-$ ognition of majority control in this manner and consideration of the way in which in the long run the stockholder is most likely to have realized on his investment, is [a] 'relevant factor' under Weinberger $v$. UOP, ... and consistent with Delaware appraisal law." "105 The court's attempt to distinguish its "limited options discount" from a minority discount is unpersuasive. ${ }^{106}$

ciently to account for the time value of money between the announcement and the merger, the court would have accepted the resulting value in its determination of fair value.

103 Market prices for all minority shares reflect a discount arising from the expropriation value, the lack of synergy value, and the pure control value. See supra text accompanying notes 73-84 (discussing three sources of control premiums). In the Shell case, market prices for the shares being valued were even lower because of the prior existence of a controlling shareholder, Royal Dutch Petroleum, which owned over $70 \%$ of Shell prior to the appraisaltriggering transaction. See In re Appraisal of Shell Oil, 607 A.2d at 1215 (noting that Royal Dutch controlled over $70 \%$ of Shell's outstanding shares).

${ }_{104}$ In re Appraisal of Shell Oil Co., 1990 WL 201390 at *31.

${ }^{105}$ Id. (quoting Smith v. Shell Petroleum, Inc., Civ. A. No. 8395, 1990 WL 84218 (Del. Ch. June 19, 1990)).

${ }^{106}$ On appeal, the Delaware Supreme Court affirmed the Shell appraisal opinion on the ground that the Chancellor did not abuse his discretion in determining fair value, stating that the "appraisal quest at the Court of Chancery level admits of a broad latitude .... We will reverse [its] findings only when they are clearly wrong and the doing of justice requires us to do so." In re Appraisal of Shell Oil, 607 A.2d at 1219. In response to an appeal by the corporation, the Delaware Supreme Court did attempt to differentiate the "liquidation value analysis" proposed by the plaintiffs and adopted by the Chancellor from the "liquidation analysis" rejected in Bell v. Kirby Lumber Corp., 413 A.2d 137 (Del. 1980). See In re Appraisal of Shell Oil, 607 A.2d at 1219-20 (arguing that Royal Dutch was "mischaracteriz[ing] the trial court's findings" and that "the court's final figure of $\$ 71.20$ is ... not the product of a liquidation analysis alone"). It is unclear from the supreme court opinion whether or not the dissenting shareholders appealed the part of the Chancellor's opinion adopting the implicit "limited options" discount. 


\section{b. Other Delaware Cases}

Subsequent to Shell, ${ }^{107}$ several Delaware courts have made one or both of the mistakes made by the Court of Chancery in Shell. In Salomon Bros. Inc. v. Interstate Bakeries Corp. ${ }^{108}$ the court rejected an upward adjustment from average price-earnings multiples (which reflected an implicit minority discount because the multiples were derived from minority share market prices) on the ground that such a "shareholderlevel" adjustment was contrary to the pro rata value doctrine established by Cavalier Oil. ${ }^{109}$ Based on the same reasoning, the court reached a similar outcome in In re Radiology Associates, Inc. Liti-

107 In addition to the cases discussed in the text, Delaware courts have addressed premiums or discounts in several other cases post-Shell. See, e.g., Grubb v. Bagley, Civ. A. No. 13882, 1998 WL 92224, at *1-2 (Del. Ch. Feb. 25, 1998) (noting the plaintiffs' expert's assertion that "marketability and minority discounts [are] prohibited by Delaware law"); Hintmann v. Fred Weber, Inc., Civ. A. No. 12839, 1998 WL 83052, at *4 (Del. Ch. Feb. 17, 1998) (acknowledging that "[t]his Court has accepted the addition of small stock premia" in calculating the discount rate); Metropolitan Life Ins. Co. v. Aramark Corp., Civ. A. No. 16142, 1998 Del. Ch. LEXIS 70, at *6-10 (Feb. 5, 1998) (granting a preliminary injunction to halt a freeze-out based on the directors' use of a "private company discount" in determining the freeze-out price); Le Beau v. M.G. Bancorporation, Inc., Civ. A. No. 13414, 1998 WL 44993, at *4 (Del. Ch. Jan. 29, 1998) (accepting a "small stock premium" in the calculation of the discount rate in a DCF analysis-despite its having the same effect and rationale as the marketability discounts rejected in Cavalier Oil-but rejecting the petitioners' and the respondents' valuations on other grounds).

${ }_{108}$ Civ. A. No. 10054, 1992 WL 94367 (Del. Ch. May 4, 1992).

109 See id. at *6 ("[T] he adjustment ... is a stockholder level adjustment. Thus, to the extent that it is, in whole or in part, a control premium adjustment, it is inappropriate."). The court was also discomfited because dissenting shareholders "conceded that the . . concepts [of control premium and minority discount] are related" but did not "undertake any analysis of the difference between market values and ... 'whole company' values in order to determine an appropriate adjustment." Id. As the court explained, their expert "simply ... decided that $15 \%$ was . . reasonable." Id. One might sympathize with the court's discomfort; however, "acknowledging the existence of the minority discount, but setting it at zero, is more arbitrary than endeavoring to find its true value." Kleinwort Benson Ltd. v. Silgan Corp., Civ. A. No. 11107, 1995 WL 376911, at *4 (Del. Ch. June 15, 1995). Finally, the Salomon Bros. court believed that such upward adjustments are not accepted in the financial community and thus should not be accepted under Weinberger. See Salomon Bros., 1992 WL 94367, at *6 ("I am not satisfied ... that a market value adjustment to compensate for an implicit minority discount is a valuation method that is generally accepted in the financial community.").

In fact, in my experience, investment bankers, who advise special committees that negotiate conflict transactions frequently, adjust market prices upward to reflect some or all of the elements of a control premium. It is true that valuations for purely financial purposes focus on (minority share) market value or a full control premium and will not attempt to arrive at a price in between the two. But, that is because the concepts of fair value and pro rata value are legal and not financial concepts. This may suggest that the Delaware Supreme Court's attempt in Weinberger v. UOP, Inc., 457 A.2d 701, 712-13 (Del. 1983), to point courts to financial experts for valuation may be unsound, at least for some parts of a valuation. 
gation. ${ }^{110}$ In both cases, the courts viewed premiums and discounts as identical. In Hodas v. Spectrum Technology, Inc., ${ }^{111}$ the court also identified control premiums and minority discounts, but reached the opposite result: it included, without comment, a $30 \%$ "control premium" to a value based on a price/cash flow multiple in order "to adjust for the fact that the ... multiple reflects a stock price for a single share on a public stock exchange and, thus, includes a minority discount." 112

As demonstrated by these cases, because the pro rata value doctrine permits discounts to be built in via the choice of valuation methodology, but then prohibits adjustments to correct for such discounts, the doctrine not only permits inconsistent outcomes, but it actually requires them! Where available, market prices are considered by the financial community in valuing firms and their stock; ${ }^{113}$ such prices are thus a "relevant factor" required to be considered by courts under Weinberger. ${ }^{114}$ Thus, an implicit minority discount will be reflected in every valuation in which the market prices are available. If the pro rata value doctrine prohibits an upward adjustment to eliminate this implicit discount, as post-Cavalier Oil cases suggest, then the fair value will necessarily reflect a minority discount (which perhaps can be mitigated by averaging the market prices with other values). Yet, the opposite result would follow if a valuation consisted solely of a DCF analysis. ${ }^{115}$ Then, pro rata value could not be adjusted downward to reflect the minority discount because of the ban on "shareholder level" adjustments. Thus, depending on the choice of valuation methodology, minority discounts may be compelled or prohibited.

110611 A.2d 485, 494 (Del. Ch. 1991) (arguing that whether the dissenter "labels the [adjustment sought] as a premium or recompense for a discount, the [adjustment] is inappropriate").

111 Civ. A. No. 11265, 1992 WL 364682 (Del. Ch. Dec. 8, 1992).

112 Id, at *2.

113 See, e.g., PRATT ET AL., supra note 4, at 203 ("Actual market transaction data can provide compelling empirical evidence of value ... [and] publicly traded corporation capital market data may provide relevant valuation guidance in many cases.").

114 See supra text accompanying notes 28-32 (describing "fair value" law after Weinberger); see also Weinberger, 457 A.2d at 713 ("Fair price ... requires consideration of all relevant factors involving the value of a company.").

115 This would occur when a company being valued was not a public company, or had a thin trading market for its shares. In either case, no reliable market price data would be readily available. 
More recently, in Kleinwort Benson Ltd. v. Silgan Corp., ${ }^{116}$ one Delaware court has attempted to reconcile this conflict. ${ }^{117}$ The Silgan Corp. court noted that all of the experts in the case agreed that minority shares "trade below [pro rata] value" and that control premiums might include more than a minority discount-they could also include synergy value. ${ }^{118}$ The defendant's expert, however, contended that any upward adjustment to eliminate this implicit discount represented a control premium barred by DGCL section $262 .{ }^{119}$ The court rejected this argument and held that the portion of a control premium that reflects a minority discount should be eliminated by an upwardly adjusted market value. ${ }^{120}$

The Silgan Corp. court then turned to the question regarding how to fix the size of the needed adjustment. Candidly acknowledging that "setting an exact figure for the minority discount comes down to an arbitrary determi-

116 Civ. A. No. 11107, 1995 WL 376911 (Del. Ch. June 15, 1995). The Silgan Corp. case is also noteworthy because it represents the first modern Delaware appraisal action in which the court appointed a neutral expert to assist in evaluating the parties' expert valuations, taxing the expert's costs to each litigant. See id. at *12. The neutral expert was instructed by the court to not arrive at a fair value, but only to provide criticism of the other experts' valuations. See id. at *1.

117 In Cooper v. Pabst Brewing Co., Civ. A. No. 7244, 1993 WL 208763, at *9 (Del. Ch. June 8,1993 ), the court also recognized that control premiums and minority discounts could be distinguished, at least in theory. In Pabst Brewing, the court reviewed a back-end merger in a two-step takeover. To arrive at fair value, it averaged the front-end tender offer price and the back-end merger price, and then reduced that amount by an arbitrary $10 \%$ to correct for over-optimistic assumptions. See id. at *8-10. The opinion contains little reasoning other than the statement that blended value in a two-step takeover "necessarily does not include much of a control premium." Id. at *9.

${ }^{118}$ See Silgan Corp., 1995 WL 376911 , at $* 3$ (citations omitted). This fact alone sufficed for the Silgan Corp. court to distinguish Salomon Bros. in which the Vice Chancellor was "not satisfied" that an upward adjustment was "generally accepted in the financial community."' Id. (quoting Salomon Bros. Inc. v. Interstate Bakeries Corp., Civ. A. No. 10054, 1992 WL 94367, at *6 (Del. Ch. May 4, 1992)). The fact that all of the experts agreed that market values reflect an implicit minority discount from a pro rata share of the total firm value does not mean, however, that they agreed that adjusting the market values upward to eliminate the implicit discount is "generally accepted." Nor did the court recite any evidence that such an adjustment was "generally accepted" in the financial community. As noted above, see supra note 107 (citing other post-Shell cases in which the Delaware courts have addressed premiums or discounts), such an adjustment is, in fact, not part of a normal financial valuation analysis, except in the context of legal cases.

119 See Silgan Corp., 1995 WL 376911, at *2 (arguing that the analysis of the petitioner's expert was "improper as a matter of law" because it included a "control premium").

${ }^{120}$ See id. at *4; see also Hintmann v. Fred Weber, Inc., No. 12839, 1998 WL 83052, at *8 (Del. Ch. Feb. 17, 1998) (approving a company-level control premium that was derived from comparable transaction data, but reducing it from $45 \%$ to $20 \%$ in order to eliminate the estimated synergy value reflected in that data); Moore v. New Ammest, Inc., 630 P.2d 167 (Kan. Ct. App. 1981) (noting that a "controlling block usually has a per share value higher than its proportionate interest, and a minority block, which does not possess the control element of value, has a lower per share value"). 
nation," the Silgan Corp. court reasoned that "acknowledging the existence of the minority discount, but setting it at zero, is more arbitrary than endeavoring to find its true value."121 The court then fixed an upward adjustment at $12.5 \%$, based on the corporation's expert's admission at trial that a reasonable estimate of the minority discount was "around 10-15\%."122

\section{Summary}

So where does Delaware law stand today on discounts and premiums? The case law is, to be blunt, a mess. The pro rata value doctrine, with its inherent indeterminacy, has contributed to, rather than alleviated, the confusion. Distinguishing between the firm value and the share value may be useful, particularly when using a methodology (such as a DCF analysis) that "looks through" the corporate form to the underlying cash flows. Yet, other evidence of value-for example, minority share market prices or prices paid in control acquisitions-necessarily reflects the attributes of the shares or the blocks of shares. Whenever such techniques are used, either discounts will be impounded in the fair values, or "shareholder level" adjustments will be necessary. To that extent, at least, Cavalier Oil should be modified.

\section{Delaware Discount LaW Is Avoidable}

Given that current Delaware rules on minority discounts are incoherent, unpredictable, and inconsistent with the appraisal statute, one might think that the only reason corporations continue to subject themselves to such rules is that they are binding. Indeed, the general perception is that they are binding. ${ }^{123}$ In fact, however, they are effectively avoidable (or nonbinding), as will be demonstrated in this Part. Even though Delaware corporate law provides for rules to determine what price the minority shareholders should be paid in conflict transactions, in both appraisal proceedings and entire fairness cases, those rules are not effectively binding.

121 Silgan Corp., 1995 WL 376911 , at *4.

122 Id.

123 See, e.g., Ian Ayres, Back to Basics: Regulating How Corporations Speak to the Market, 77 VA. L. REV. 945, 948 n.16 (1991) (asserting that minority appraisal rights are "immutable"); Bernard S. Black, Is Corporate Law Trivial?: A Political and Economic Analysis, 84 NW. U. L. REV. 542, 571 (1990) (noting that appraisal rights are rarely the mandatory rule, but are not given much weight by investors); Melvin Aron Eisenberg, The Structure of Corporation Law, 89 COLUM. L. REV. 1461, 1481 (1989) (describing appraisal rights under DGCL section 262 as mandatory and asserting a "duty of loyalty ... that cannot be substantially altered"); Jeffrey N. Gordon, The Mandatory Structure of Corporate Law, 89 COLUM. L. REV. 1549, 1553 n.16 (1989) (listing appraisal rights under DGCL section 262 as mandatory). 
Corporations have a simple way of establishing by contract the method by which the "fair value" will be determined. By including appropriate provisions in the terms of its common stock set forth in its charter (or in buy-sell agreements between a corporation and its shareholders), ${ }^{124}$ a corporation may provide contractually for the inclusion (or exclusion) of minority discounts in determining fair value.

\section{A. Contracting to Exclude Discounts}

The legitimacy of a charter or contractual provision requiring that minority shareholders be paid more than would otherwise be required by background Delaware law-for example, a full control premium-would not appear to raise any serious issues. Corporations frequently issue mandatorily redeemable stock, the terms of which require the corporation to pay the shareholders a set or formula price after some period of time or upon the occurrence of some contingency. ${ }^{125}$ Likewise, a number of companies have adopted "fair price" charter provisions intended to ensure that in the event of a hostile takeover, the acquiror and its affiliates will pay minority shareholders a minimum price. For example, the charter of Unisys Corporation generally provides that in the event any person (together with Unisys's affiliates) acquires more than $20 \%$ of Unisys's outstanding voting stock without obtaining prior approval from the board of directors, the acquiring person may not engage in any transaction with Unisys (whether it be a freeze-out, second-step merger, or other control transaction) without paying the minority shareholders a price that is at least as great as

124 Corporations also retain the option of negotiating with shareholders directly in order to purchase their shares in individual transactions or of conducting a self-tender for a specified percentage of shares. Similarly, control persons have the ability to establish a new corporation to launch a $100 \%$ "any-and-all" tender offer for the first company's shares. Although the duty of candor and federal securities laws would govern such transactions, the transactions generally would not be subject to entire fairness review, nor would they trigger appraisal rights. Thus, a company can largely (if not completely) eliminate its shareholder base without judicial review of the price paid. Where such transactions involve paying for a substantial number of shares, they almost always occur at prices above the current market clearing price. See MERGERSTAT REVIEW 1997, supra note 13, at 42 (reporting that the median premium to market price for going private transactions from 1987 through 1996 varied between $8 \%$ and $35 \%$ ). This would appear to support my analysis, infra, in Part IV that a rule including discounts is not the optimal rule.

125 See, e.g., JACK S. LEVIN, StruCturIng Venture CAPITAL, PRIVATE Equity AND ENTREPRENEURIAL TRANSACTIONS 218 (1997) (listing mandatory redemption as a "sample term" of the common venture capital investment arrangement and discussing its tax implications); see also infra note 245 (describing buy/sell agreements which have the same effect as mandatory redemption provisions). 
that paid by the acquiring person in order to obtain control. ${ }^{126} \mathrm{~A}$ broader charter provision requiring the payment of a control premium in the event of a conflict transaction by the management or a preexisting controlling shareholder easily fits into this mold and would be undoubtedly legitimate in Delaware.

\section{B. Contracting to Include Discounts}

Designing charter or contractual provisions to provide for the inclusion of minority discounts requires more ingenuity, but it, too, appears feasible. For example, a corporation could include in its charter (or in a buy/sell agreement) a provision that its common stock be redeemable ${ }^{127}$ at the option

126 See Unisys Corp., SEC Reg. St. No. 333-08933 on Form S-3 (July 26, 1996) (on file with author) (describing fair price provision); see also Minnesota Power \& Light Co., SEC Reg. St. No. 333-02109 on Form S-3/A (June 19, 1996) (on file with author) (same); Roosevelt Financial Group, Inc., SEC Reg. St. No. 333-04499 on Form S-4 (June 3, 1996) (on file with author) (same).

${ }^{127}$ To my knowledge, the only example of common stock that is redeemable at the option of the corporation is the common stock issued to former Genentech shareholders in the 1990 Roche/Genentech transaction. See In re Genentech, Inc., Civ. A. No. 11377, 1990 WL 78829 , at *9 (Del. Ch. June 6, 1990) (rejecting duty of candor claims in connection with the transaction). The court described the redeemable common stock issued in that transaction as a "unique form of equity security that has never before been introduced." Id. at *12 n.4. The new Genentech common stock was redeemable until June 30, 1995, at the election of Roche, which became the $60 \%$-owner of Genentech in the transaction. Redemption prices increased from $\$ 38$ to $\$ 60$ per share in fixed increments, initially of $\$ 1$ per quarter and, after June 30 , 1991 , of $\$ 1.25$ per quarter. See id. at *12 n.5. In 1995, Roche and an independent committee of directors representing the public Genentech shareholders negotiated (and the Genentech shareholders approved) an extension of the redemption right. Roche was prohibited by a governance agreement with Genentech from acquiring the Genentech public shares for six years at a price less than the stock's redemption price. See id. at *10; see also Ellingwood v. Wolf's Head Oil Ref. Co., 38 A.2d 743, 747 (Del. 1944) (stating that a charter "may contain any provision with respect to the stock to be issued by the corporation ... that is agreed upon by the stockholders, provided that the provision ... is not against public policy"). While DGCL section 151(b) was amended in 1990 to clarify that Delaware corporations could issue redeemable common stock, a 1969 amendment to DGCL section 151(e) permitting exchangeable common stock effectively allowed for the same result. Compare DEL. CODE ANN. tit. 8, $\S 151$ (b) (1998), with DEL. CODE ANN. tit. 8, § 151(e) (1998). Delaware courts have approved redeemable stock, exchangeable stock, convertible stock, stock with super-voting rights, lesser voting rights or no voting rights, and stock with only voting rights (no dividend or liquidation rights). See WELCH \& TUREZYN, supra note $25, \S 151$, at 243-57 (discussing classes and series of stock, changes in the statute, rights of stockholders, preferred stock, redeemable shares, directors' powers, convertible securities, and controlling stockholders); see also MODEL BUS. CORP. ACT ANN. \$ 6.01 (1994) (permitting redeemable common stock); id. $\$ 6.01 \mathrm{cmt}$. 3c (justifying redeemable common stock on the ground that consensual share transfer restrictions can create essentially the same effect); id. $\S 6.01$ note on statutory comparison (Supp. 1997) (stating that 25 states expressly permit redeemable common stock while eight others allow a limited power of redemption of common stock). 


\section{of the corporation. ${ }^{128}$ DGCL section $151(\mathrm{~b})$ expressly provides that}

[t]he stock of any class or series may be made subject to redemption by the corporation at its option ... provided however, that at the time of such redemption the corporation shall have outstanding shares of at least 1 class or series of stock with full voting powers which shall not be subject to redemption .... Any stock ... may be redeemed for cash, property or rights, ... at such time ... prices... or rates, and with such adjustments, as shall be stated in the [charter].

In essence, then, any corporation may retain the right to freeze out its shareholders at any time for cash-at a specific price (or prices) or at a formula price. ${ }^{130}$ That formula price could provide, for example, that share-

${ }^{128}$ Common stock redeemable at the option of the corporation should be distinguished from common stock redeemable at the option of the holder, which is typically issued by-indeed, is the defining characteristic of-open-end investment companies (mutual funds). See generally 1 TAMAR FRANKEL, THE REGULATION OF MONEY MANAGERS (1978 \& Supp. 1998).

${ }^{129}$ DEL. CODE ANN. tit. $8 \S 151$ (b). Prior to July 1, 1998, DGCL section 151(b) required that a company have at least one class of nonredeemable voting stock, but this was a negligible constraint because only one share needed to be authorized, and it could have been held by the firm's founder or some neutral bank or trustee. See id. Thus, the redeemable common stock could have had full voting, dividend, and liquidation rights, just like ordinary common stock. For all practical purposes, control and ownership could have resided in the hands of holders of the redeemable common stock. In addition, a corporation could have achieved the same end by issuing common stock exchangeable (under DGCL section 151(e)) at the option of the corporation into immediately redeemable preferred stock issued under DGCL section 151(b). See id. §151(b), (e). Unlike DGCL section 151(b), DGCL section 151(e) does not contain a proviso that the corporation maintain at least one class of nonexchangeable voting stock at all times. By issuing a single class of exchangeable common stock, a corporation could then use a two-step process to freeze out common shares at a preset formula price: first, common shares would be mandatorily exchanged for redeemable preferred shares; second, the preferred shares would immediately afterwards be redeemed for cash. The corporation would thereby continue to have at least one class of nonredeemable stock with full voting rights, as required by $\mathrm{DGCL}$ section $151(\mathrm{~b})$.

The doctrine of independent legal significance strongly supports the legitimacy of such a class of stock. See Edelman v. Phillips Petroleum Co., No. 7899, 1985 WL 11534, at *7 (Del. Ch. Feb. 12, 1985) (upholding a reclassification of common stock partly into common stock and partly into redeemable preferred stock that was redeemed immediately following the reclassification).

${ }^{130}$ Some commentators have noted an alternative method for corporations in many jurisdictions to effectively avoid appraisal rights through the choice of transaction structure. See, e.g., Roberta Romano, Answering the Wrong Question: The Tenuous Case for Mandatory Corporate Laws, 89 COLUM. L. REV. 1599, 1600 (1989) (noting that the ability to choose transaction structure makes the rule that shareholders must vote on mergers "completely optional"). For example, the sale of substantially all of a Delaware corporation's assets does not trigger appraisal rights, while a merger does. Compared to "fair price" charter provisions, buy/sell agreements, and redeemable common stock ("discount contracts"), transaction choice is a blunt weapon. Discount contracts vary from traditional corporate structures only by specifying how the "fair value" will be determined. In addition, transaction choice only permits contracting around appraisal rights. Discount contracts permit contracting around "fair 
holders receive the market price on a recent trading day, the average bid/ask prices over the thirty trading days prior to the redemption date, or the book value as adjusted to reflect cash flows measured over a specified period. Alternatively, a corporation could provide contractually for shareholders to receive "fair value" as determined by a court (or private appraiser ${ }^{131}$ ) using specified guidelines, including, for example, the specific requirement that the "fair value" of the minority shares be discounted to reflect their minority status.

Whatever the specifics, a corporation effectively could, by including such provisions, ensure that whenever it wanted to freeze out minority shareholders (on the back end of a two-step takeover or in an MBO, for example), it could do so pursuant to the redemption provisions in its charter, leaving no stockholders to pursue a judicially determined or reviewed "fair value" determination. No stockholders would remain to obtain or pursue statutory appraisal rights. Such a result is consistent with the limited Delaware precedent. In an appraisal of the Ford Holdings Company, Chancellor Allen based his determination of the "fair value" of preferred stock on the terms of the certificate of designations establishing the terms of the stock, which expressly and clearly provided for a contractually determined "fair value" in such circumstances. ${ }^{132}$

Further, as long as the redemption price was fixed or was determined pursuant to a market-based formula, and as long as the corporation complied

value" determinations generally. That is to say, under the entire faimess doctrine, Delaware courts will review the price paid in a conflict transaction, regardless of its structure. Because conflict transactions involve the duty of loyalty, Delaware courts still will scrutinize closely the price paid in the transaction in order to see if it is a "fair price"-even in an asset sale that does not trigger appraisal rights. See John C. Coffee, Jr., The Mandatory/Enabling Balance in Corporate Law: An Essay on the Judicial Role, 89 CoLUM. L. REv. 1618, 1648-52 (1989) (describing the general judicial unwillingness to permit waivers of duty of loyalty claims based on conflict transactions).

${ }^{131}$ Cf. Wojdak v. Greater Phila. Cablevision Inc., 664 A.2d 587, 591 (Pa. Super. Ct. 1995) (upholding the application of the minority and marketability discounts by an appraiser of interests in a Delaware limited partnership pursuant to the terms of the limited partnership agreement), aff'd, 684 A.2d 121 (Pa. 1996), rev'd on other grounds, $707 \mathrm{~A} .2 \mathrm{~d} 214$ ( $\mathrm{Pa} .1998)$ (reversing on the ground of ex parte communications). "[B]inding determination by a third party appraiser selected pursuant to a private agreement is basically the equivalent of arbitration, and judicial review thereof is governed by the Delaware Arbitration Act" and must be upheld "as long as it can rationally be derived from the parties' agreement or submission to the arbitrators and is not completely irrational." See Wojdak, 707 A.2d at 591.

${ }^{132}$ See In re Appraisal of Ford Holdings, Inc. Preferred Stock, 698 A.2d 973, 974 (Del. Ch. 1997) (holding that the amount determined in a certificate of designation of preferred stock constitutes the "fair value" of the stock); $c f$. Hintmann v. Fred Weber, Inc., No. 12839, 1998 WL 83052, at *10 (Del. Ch. Feb. 17, 1998) (declining to address a waiver of a "fair value" determination in an appraisal proceeding because the waiver was in the bylaws, rather than in the charter, and was not express and clear). 
with its disclosure obligations under the federal securities laws during the relevant measurement period, ${ }^{133}$ it would be highly unlikely in most instances for the minority shareholders to challenge successfully a redemption in an "entire fairness" litigation. ${ }^{134}$ Because the redemption would be pursuant to the express terms of the corporation's charter (or collateral agree-

133 Failure to disclose a material fact during a redemption measurement period based on market prices could be viewed as a violation of Rule 10b-5. Compare Jordan v. Duff \& Phelps, Inc., 815 F.2d 429, 436 (7th Cir. 1987) (holding that the failure of a company to disclose its impending merger negotiations, resulting in the buyout of an employee's stock at the book value formula price and the forfeiture of an option on additional shares, precluded summary judgment for the corporation with respect to a violation of Rule 10b-5), and Zahn v. Transamerica Corp., 162 F.2d 36, 44 (3d Cir. 1947) (finding that the redemption of convertible preferred stock at a time when the corporation failed to disclose its intent to dissolve breached a duty of good faith, which required the full disclosure of facts material to the decision to convert), with St. Louis Union Trust Co. v. Merrill Lynch, Pierce, Fenner \& Smith Inc., 562 F.2d 1040, 1046 (8th Cir. 1977) (holding that a buyout at a preagreed formula price based on the book value did not require the payment of a different price solely because the company went public a few weeks later at a higher price), and Kerrigan v. Merrill Lynch, Pierce, Fenner \& Smith, Inc., 450 F. Supp. 639, 645 (S.D.N.Y. 1978) (same).

134 See Baron v. Wolf, No. 4972, 1976 WL 2444, at $* 2$ (Del. Ch. Jan. 15, 1976) (upholding the redemption of preferred stock pursuant to a formula because a formula redemption price is permitted by the DGCL); Corbett v. McClintic-Marshall Corp., 151 A. 218, 221 (Del. Ch. 1930) (upholding a certificate making the preferred stock redeemable at the book value even though the book value was disproportionately low compared to the market or fair values because judicial intervention would improperly usurp the discretion of the directors and the freedom of contract of the shareholders); Lewis v. H.P. Hood \& Sons, Inc., 121 N.E.2d 850, 852 (Mass. 1954) (upholding a redeemable common stock provision on the ground that the buyer had voted for or purchased shares knowing of the redemption provision). Compare Lawson v. Household Fin. Corp., 152 A. 723, 727-28 (Del. 1930) (holding that a corporation has the power to purchase its own stock at the formula price with the terms of the contract of purchase as fixed in the charter), and Glens Falls Ins. Co. v. National Bd. of Fire Underwriters Bldg. Corp., 314 N.Y.S.2d 80, 86 (Sup. Ct. 1970) (holding that the repurchase of shares pursuant to a membership agreement between a corporation and its shareholders did not constitute a prohibited form of redemption under the New York Business Corporation Law and was thus enforceable), aff'd, 318 N.Y.S.2d 915 (App. Div. 1971), with Greene v. E.H. Rollins \& Sons, Inc., 2 A.2d 249, 252 (Del. Ch. 1938) (refusing to uphold a mandatory formula buyout provision in a charter that was triggered by the termination of employment on the ground of public policy because the restriction had no business purpose), and Starring v. American Hair \& Felt Co., 191 A. 887, 891 (Del. Ch. 1937) (finding that a corporation could not redeem its common stock under the statute), aff'd 2 A.2d 249 (Del. Ch. 1938). Starring and Greene were decided under a predecessor statutory provision, and so are of doubtful ongoing authority. See St. Louis Union Trust Co., 562 F.2d at 1046-47 (noting that the DGCL was amended to eliminate the need to demonstrate a "business purpose" for restrictions such as those rejected in Greene); Kerrigan, 450 F. Supp. at 645 (same); Mitchell Assocs. v. Mitchell, Civ. A. No. 6064, 1980 Del. Ch. LEXIS 562, at *8-9, *11 (Dec. 5, 1980) (upholding a corporation's right of first refusal under DGCL section 202(c)); WELCH \& TUREZYN, supra note $25, \S 202$, at 303 (noting that DGCL section 202 "may well validate even such a restriction as was invalidated in Greene"). 
ment), the force of any shareholder claim of surprise or unfairness would be greatly reduced, if not eliminated altogether. ${ }^{135}$

Still, an entire fairness claim might have force in two circumstances. First, courts might well intervene-for sound policy reasons, as discussed in Part IV-where, after investors have committed their capital to the corporation, redemption provisions are added through a midstream charter amendment, reclassification, or merger. ${ }^{136}$ Second, Delaware courts may have some concern where redemption provisions were used to shift control to, or prevent a shift of control from, management. In that instance, an isolated Delaware Chancery case from the 1970s suggests that the use of redemption provisions for the primary purpose of affecting control could be subject to scrutiny under the entire fairness test. ${ }^{137}$ Even that case is of doubtful authority, however. ${ }^{138}$ More importantly, in a large number of conflict

135 See Grubb v. Bagley, No. Civ. A. No. 13882-NC, 1998 WL 92224, at *1, *3 (Del. Ch. Feb. 25, 1998) (noting with apparent approval that the "company had a contractual right to buy stock for book value in specific circumstances," but holding that a contract formula was not applicable given that the company had pursued a freeze-out merger rather than exercising its rights under the contract).

${ }^{136}$ Cf. B \& H Warehouse, Inc. v. Atlas Van Lines, Inc., 490 F.2d 818, 823 (5th Cir. 1974) (invalidating a restraint on alienation by a charter amendment made after a shareholder purchased stock); Metropolitan Life Ins. Co. v. Aramark Corp., Civ. A. No. 16142, 1998 Del. Ch. LEXIS 70, at *6-7 (Feb. 5, 1998) (enjoining preliminarily the reclassification and cash freeze-out of shares where the freeze-out price included a "private company discount").

137 See Petty v. Penntech Papers, Inc., 347 A.2d 140, 143 (Del. Ch. 1975) (restraining temporarily the redemption of convertible preferred stock where the evidence suggested that the redemption was primarily for the purpose of maintaining management's control in anticipation of the termination of the voting trust).

${ }^{138}$ Penntech Papers was decided on a limited record and an expedited basis, reducing its value as precedent. It has been cited favorably in only one Delaware Supreme Court opinion, Singer v. Magnavox Co., 380 A.2d 969, 979 n.10 (Del. 1977), as support for the proposition that a corporate control transaction must be predicated on a "business purpose" other than simply to benefit the control persons. This holding was overturned in Weinberger v. UOP, Inc., 457 A.2d 701, 704 (Del. 1983).

Subsequent to Penntech Papers, the Delaware Supreme Court in both Unocal Corp. v. Mesa Petroleum Co., 493 A.2d 946 (Del. 1985), and the more recent Unitrin, Inc. v. American General Corp., 651 A.2d 1361 (Del. 1995), reviewed stock buybacks, which are analogous to redemptions. In both cases, management-sponsored buybacks of common stock, concededly designed to maintain the existing management's control of the corporation, were upheld as legitimate uses of corporate funds. See Unitrin, 651 A.2d at 1373 (applying the business judgment rule); Unocal, 491 A.2d at 955-56 (same). Unitrin, in fact, interpreted Unocal and its progeny to permit such transactions whenever they are not "coercive" or "preclusive" and fall within a "range of reasonableness," a standard of review considerably more deferential than the entire faimess doctrine applied in Penntech Papers. Unitrin, 651 A.2d at 1386-87. The manner in which a court would interpret the concepts of "coercion" and "preclusion" in the context of a common stock redemption is unclear. Redemption provisions, however, could be written to make it explicit that no judicial review is desired or expected. Cf. HB Korenvaes Invs., L.P. v. Marriott Corp., Civ. A. No. 12922, 1993 WL 257422, at *15 (Del. Ch. July 1, 1993) (rejecting the arguments of preferred stockholders that the literal terms of a pre- 
transactions, control is already in the hands of the promoter of the transaction. For example, an eighty-percent shareholder may seek to freeze out the minority shareholders. In those instances, Delaware case law does not indicate a judicial inclination to set aside the charter terms and scrutinize a facially valid redemption. ${ }^{139}$

Judicial review of an analogous type of charter provision buttresses the conclusion that common stock redemptions would not be given strict judicial scrutiny outside the context of midstream changes or takeover fights. Many corporations require shareholders to enter into agreements restricting transfer of their stock, providing the corporations the right to acquire the shares at a formula price upon certain specified events (such as death or the termination of employment). DGCL section 202 generally authorizes such restrictions, and courts in and outside of Delaware have upheld such restrictions as valid. ${ }^{140}$

In summary, corporations have at their disposal several means of contracting around current rules regarding discounts. Contracts to exclude discounts are straightforward; contracts to include them are a little less so. As argued in Part IV, neither type of contract appears to present any serious policy issues in the context of initial stock issuances. At least in the case of freeze-outs of minority shareholders by controlling shareholders, and probably in anticipation of any conflict transaction, such discount contracts could permit a corporation to freeze-out shares at a price reflecting the in-

ferred stock should be ignored on the ground that parties who contract with respect to one type of corporate right will not be assumed to have intended their contract to affect another right unless their contract otherwise cannot be interpreted meaningfully).

139 Delaware corporations expressly have been permitted to issue redeemable common stock only since 1990 , and as noted in the text, few corporations have issued redeemable common stock. This explains why there are no Delaware cases directly on point. Preferred stock has long been redeemable, however, and corporations have routinely issued redeemable preferred stock since the 1920s. See Paul W. Jones, Redeemable Corporate Securities, 5 S. CAL. L. REV. 83, 83 (1931) (noting that, since the introduction of redeemable corporate securities in 1874, "it has become the accepted practice to insert some form of redemption clause in almost every corporate bond"). Penntech Papers, as discussed in notes 137 and 138, supra, is the only reported case in which a Delaware court intervened to regulate a redemption of preferred stock. In addition, notwithstanding the apparent lack of authority to include redemption provisions in the terms of common stock of Delaware corporations prior to 1990, a number of companies did so, although for a reason very different from the desire to contract around fair value determinations-to provide shareholders with "put" rights as a form of takeover defense, See Craig B. Smith, Fair Price and Redemption Rights: New Dimensions in Defense Charter Provisions, 4 DEL. J. CORP. L. 1, 22-27, 34-38 (1978) (discussing the right of redemption or "put" provisions, and including an example from the Rubbermaid Inc. Proxy Statement (Mar. 24, 1978)).

${ }^{140}$ See supra note 134 (noting that the courts in St. Louis Union Trust Co. and Kerrigan upheld such restrictions). 
clusion (or exclusion) of minority discounts, notwithstanding the unpredictability of Delaware's pro rata value doctrine.

\section{THE PUZZLE OF DISCOUNT LAW}

\section{A. Firms Have Not Contracted Around Discount Law}

Despite having the ability to contract around a judicially defined "fair value," corporations have not done so. None of the fifty largest corporations on the New York Stock Exchange have done so. None of the first fifty companies to undertake initial public offerings during 1996 did so. Many examples of transfer restrictions of the sort discussed in Part II can be found, but only a de minimis number of corporations have issued common stock that is redeemable at the option of the corporation. ${ }^{141}$ I have found no companies that attempt to specify discount rules for conflict transactions. In short, despite the fact that corporate law already provides a clear method for avoiding a judicial determination of fair value, market participants have not used that method and instead have (implicitly) endorsed the current practice of fair-value determinations.

Together with the analyses in Parts I and II, the empirical fact that firms have not contracted around rules regarding minority discounts presents a puzzle. $^{142}$ Ideally, rules of corporate law should at least be consistent. With merger, $\mathrm{MBO}$, and takeover activity remaining at high levels, a consistent, reliable discount rule would permit better corporate and investment planning. The meaning of "fair value" necessarily influences the number and nature of such transactions, making a predictable and complete understanding of these concepts particularly important to the makers of both corporate decisions and public policy. The meaning of "fair value" in conflict transactions is particularly important because such transactions often involve personal financial risk for participants. Failure to understand correctly and apply the law of fair value could, in theory, lead a court to undo a conflict transaction; to require substantially increased consideration; ${ }^{143}$ or to impose personal liability on the directors, officers, and agents involved. ${ }^{144}$

141 See supra note 127 (citing the 1990 Roche/Genentech transaction as the only example to the author's knowledge of common stock that is redeemable at the option of the corporation).

142 I thank Jeff Gordon for this point.

143 See, e.g., Enserch Corp. v. MacLane Gas Co., No. 29, 1993 WL 541911, at *5 (Del. Nov. 18, 1993) (denying a motion for a rehearing en banc of a decision affirming a judgment against defendants for failure to consider inflation in fixing the fair value).

144 See, e.g., Smith v. Van Gorkom, 488 A.2d 858, 893 (Del. 1985) (holding the directors personally liable for a breach of fiduciary duties). 
Thus, parties have an incentive to contract around existing discount law. As discussed more extensively in Part IV, whether or not discounts should be permitted as a general matter is debatable. A clear rule barring discounts might be expected to increase ex ante share value because investors would pay to eliminate the risk of conflict transactions at discounted prices. Conversely, one could imagine that a clear rule permitting discounts might increase ex ante share value by facilitating control transactions. Yet, issuing firms have not used their ability to contract for either rule.

This Part considers three possible answers to the discount puzzle: (1) the transaction costs associated with contracting around existing discount rules may outweigh potential benefits (the "transaction costs hypothesis"), (2) firms may be constrained from contracting around existing discount rules as a result of the types of externalities associated with innovative departures from contractual norms (the "externality hypothesis"), and (3) investors may mistakenly take Delaware discount law at face value (and think that no discounts are permitted) and "overpay" for minority shares (the "overpayment hypothesis"). These hypotheses are not mutually exclusive. Externalities associated with innovation may be understood as a form of transaction cost or may operate as a conceptually distinct, but related, reason for not contracting around default rules. Likewise, some investors might mistakenly "overpay" for minority shares, producing a negative offset to the potential benefit of a clear rule regarding discounts, thereby making that potential benefit less than the transaction costs associated with establishing a clear rule.

\section{B. Transaction Costs}

One potential explanation of the puzzle presented by minority discounts is that the transaction costs associated with contracting around fair value determinations outweigh the potential benefits. Economic theory identifies two underlying features of contracting: ${ }^{145}$ bounded rationality ${ }^{146}$ and opportunism. ${ }^{147}$ In response to these features, private and public mechanisms

145 See generally OLIVER E. WILlIAMSON, THE MECHANISMS OF GOVERNANCE (1996).

146 "Bounded rationality" is the seemingly straightforward concept that humans are "limited in knowledge, foresight, skill, and time" and are ultimately unable to act with perfect or "objective" rationality. HERBERT A. SMON, MODELS OF MAN 198-99 (1957).

147 "Opportunism" captures the fact that economic actors may attempt to further their own ends through guile, deception, or breach of promise. In particular, the risk of opportunism arises from the combination of uncertainty, which may be viewed as a feature of bounded rationality, and "asset specificity," which in general terms is the degree to which an asset can be "redeployed" to alternative uses without loss of value. See WILLIAMSON, supra note 145, at 59-60. Asset specificity may present special problems in the context of close corporations. See Hetherington \& Dooley, supra note 37, at 3-6 (describing how the dissolution of an asset- 
(contracts, organizations, governance structures) have been developed to the advantage of all participants. These features also imply that the capacities of corrective mechanisms are limited. Judicial determinations of fair value, as described in Part $\mathrm{I}$, as well as potential contracts to fix prospectively rules for fair value determinations, as described in Part II, may be seen as mechanisms for coping with (and are hampered by) bounded rationality and opportunism.

Transaction cost theory suggests an answer to the discount puzzle: bounded rationality and opportunism make it less costly to continue to accept inconsistent fair value determinations in a public (judicial) order than to establish a consistent rule regarding discounts through private ordering. The puzzle thus lies in identifying ways in which bounded rationality and opportunism make it difficult to specify a consistent rule regarding discounts, even accounting for the ways in which a clear rule would ameliorate the problems presented by bounded rationality and opportunism. In short, how do the costs of the current default rule compare to the costs of a private rule?

\section{Costs of the Current Rule}

First, consider the costs of the current rule. Transaction cost theory suggests two sources of costs. From a firm's perspective, the current rule (1) makes planning and executing conflict transactions more uncertain and more costly ${ }^{148}$ (exacerbating bounded rationality) and (2) increases litigation and related liability risks ${ }^{149}$ (exacerbating opportunism by minority share-

specific close corporation creates opportunities for internal exploitation); Charles R. O'Kelley, Jr., Filling Gaps in the Close Corporation Contract: A Transaction Cost Analysis, 87 Nw. U. L. REV. 216, 222-24 (1992) (describing how the "all-or-nothing allocation of risk" that asset specificity brings may be unattractive to prospective investors).

148 For example, a firm may view a conflict transaction as profitable if, but only if, the price to be paid is less than $\$ X$, where $\$ X$ is based on the recent market prices for minority shares and thus reflects an implicit minority discount. If the transaction proceeds on the assumption that implicit minority discounts are permitted, only to have a court adjust the fair value upward above $\$ \mathrm{X}$ to eliminate the implicit discount, then the firm ultimately may be forced to abandon the transaction. Transaction related costs (for example, management time and expense, out-of-pocket expenses, and investment banking, accounting, and legal fees) will have been wasted. Alternatively, the firm may decide that, having incurred irretrievable sunk costs, the second best solution is to proceed with what would have been viewed, ex ante, as an inefficient use of corporate resources.

149 Fiduciaries under Delaware corporate law may not contractually limit their liability for breaches of the duty of loyalty, see DEL. CODE ANN. tit. 8, § 102(b)(7) (Supp. 1996) (prohibiting charter provisions that eliminate or limit the directors' liability for a breach of the duty of loyalty), and fiduciaries are therefore exposed to potential personal liability for promoting a self-interested transaction that is subsequently viewed as unfair by a court. Although the ordinary remedy in a corporate freeze-out or recapitalization is for the transaction terms to 
holders). From an investor's perspective, the current rule (1) lowers investment returns by increasing uncertainty regarding future cash flows on investments (exacerbating bounded rationality) and (2) increases the possibility of conflict transactions at unexpectedly low prices ${ }^{150}$ (exacerbating opportunism by controlling shareholders).

Assuming the semi-strong form of the efficient market hypothesis, investors would pass along to the firm costs that would otherwise fall on them. Thus, a third potential cost of the current rule for issuing firms is the indirect cost of higher capital costs. ${ }^{151}$ If, as seems likely, investors cannot reliably distinguish between firms that are likely to engage in future conflict transactions and those that are not, then the latter firms would gain from precommitting to pay undiscounted prices in conflict transactions. By doing so, they would increase the expected future value of their stock, and thus could command a higher initial offering price and reduce their costs of capital.

\section{Costs of a New Rule}

Turning to a new rule on discounts, which would be established by private contract, bounded rationality implies that two sorts of transaction costs may confront firms attempting to fix their own discount rules: (1) traditional transaction costs such as developing, marketing, and enforcing such rules and (2) a particular form of "signaling" cost that such rules may create.

Three traditional sources of transaction costs can be expected: ${ }^{152}$ learning how to set the new rule (research costs); (2) negotiating a clear contract, which in the case of public companies, essentially reduces to

be revised to reflect an increased price, the entire cost of the increased price will, in the case of $\mathrm{MBOs}$, reduce the equity of the target corporation, producing almost the same result as imposing personal liability on the individual members of management.

${ }_{150}$ For a rough estimate of such costs, see infra note 236 , which estimates the size and frequency of discounts in conflict transactions.

${ }^{151}$ If the semi-strong EMH is correct, then all of the costs discussed in the text will be reflected, in the end, by higher costs of capital, and thus be borne by firms. If the overpayment hypothesis is true, issuing firms in Delaware are already capturing whatever value arises as a result of mispricing, and thus would not stand to gain from an improvement made to capital market pricing by the establishment of clear discount rules. See infra Part III.D (explaining that issuing firms may be benefiting already from the perception that they are operating under a "no-discount" regime by raising capital with a lower level of dilution, yet reducing the amount of cash needed at the time of a conflict transaction to freeze out the minority shareholders). If the overpayment hypothesis is not correct, or is only partly correct, however, then issuing firms may be hurt by the current rule.

${ }^{152}$ Cf. Black, supra note 123, at 556-57 (listing forethought, reincorporation expenses, and the risk of judicial or legislative reinstatement of the avoided rule as examples of rule avoidance costs). 
learning how to effectively sell investors on the benefits of the contract (marketing costs); and (3) ensuring that the contract will be enforceable, both legally and practically (enforcement costs). ${ }^{153}$

Research costs are not trivial. As sketched out in Part II, although setting a discount rule would appear to present little difficulty as a matter of simple drafting, a firm must also make sure that other rules (for example, tax laws, accounting requirements, regulatory or licensing rules, and consent requirements) do not impose unrelated, additional costs on a company that attempts to rely on the new rule. Such rules may make a theoretically viable discount rule useless. The tax, accounting, and legal research needed to confirm that a new rule on discounts would work for a particular firm would be costly. ${ }^{154}$

Turning to marketing costs, consider a firm that seeks to issue common stock redeemable at the option of the company. Issuers already have an effective "call" on their own stock-they can engage in a freeze-out or buyout (as did Levi Strauss) in which public shareholders are required to exchange their shares for a cash payment. ${ }^{155}$ Even though this implicit call is functionally no different from an explicit redemption right, adoption of an explicit redemption right would require an investor-by-investor marketing program because investors would need to be educated on existing corporate

153 These categories loosely correspond to those adumbrated in OLIVER HART, FRMS, CONTRACTS AND FNANCIAL STRUCTURE 23 (1995), identifying the costs of (1) thinking of and planning for various contingencies, (2) negotiating about such plans, and (3) writing down the plans in such a way that an outside authority can understand and enforce them. For the relationship between these costs and bounded rationality generally, see RONALD COASE, THE FIRM, THE MARKET AND THE LAW (1988), arguing that economics is the science of human choice, and OLIVER F. WILLIAMSON, THE ECONOMIC INSTITUTIONS OF CAPITALISM (1985), developing the theory of transaction costs, specifically the costs of planning, adopting, and monitoring task completion in our economy.

154 By way of illustration, the legal costs reflected in the exhibits to registration statements filed with the Securities and Exchange Commission for unusual securities (such as LYONS, PERCS, TOPRS, and MIPS) exceed those reflected in the registration statements for "plain vanilla" securities (such as common stock, senior debt, and conventional preferred stock) by $400 \%$ or more. Compare Time Warner \& Co., Reg. St. No. 33-61579 on Form S-3 (Aug. 4, 1995) (offering $\$ 370$ million in common stock, and listing the legal fees at $\$ 87,500$ ), with Time Warner Co., Reg. St. No. 33-60203 (Aug. 4, 1995) (offering $\$ 375$ million in PERCS, and listing the legal fees at $\$ 300,000$ ). Compare Sears Roebuck \& Co., Reg. St. No. 33-41485 (Aug. 1, 1991) (reporting a $\$ 1$ billion debt shelf, and listing the legal fees at $\$ 30,000$ ), with SunAmerica Inc., Reg. St. No. 333-14201 (Oct. 31, 1996) (offering \$375 million in TOPRS, and listing the legal fees at $\$ 150,000$ ).

155 At least this is true for companies where a single shareholder or parent company has majority control. For companies that have no such controlling shareholder, any attempted MBO or similar conflict transaction would trigger so-called Revlon duties, presenting the possibility that initiating such a transaction could result in an "auction" and the sale of the company to a third party. See 1 LIPTON \& STEINBERGER, supra note 2, at $\S 1.07[2]$ (discussing the Revlon case). 
law. Investors rely to a large extent on prevailing market prices for much of their information about potential investments. ${ }^{156}$ The more basic and general the feature, the more likely investors will rely on existing markets to "price" the feature, ${ }^{157}$ and current discount law is basic and general. Thus, existing law on discounts will need to be explained to investors in order for them to evaluate a variation from that law, even for firms that precommit to a "no-discount" rule. 158

Marketing costs for novel securities are often underappreciated, and can be critical. A typical "road show" for a stock offering is structured to give prospective investors a limited amount of "face" time with management to understand the firm's business plan, its industry expectations, and its managerial quality. ${ }^{159}$ "Face" time is limited by the need to make a sales pitch to a large number of prospective investors, many of whom may decide not to participate, and by the opportunity costs confronting investors. Per investor, "face" time is often limited to as little as an hour. To spend a substantial portion of that crucial hour explaining novel discount provisions represents a large opportunity cost for the firm. It will not suffice to have investors read the prospectus, even if the securities law might permit that, because industry custom (and reputational constraints) demand that unusual features (such as call provisions) be noted and justified orally.

Finally, attempts to contract for a clear discount rule are not without enforcement risks. As discussed in Part II, although I believe a new discount rule should be enforceable under current Delaware law, the question is not free from doubt, particularly where the rule would establish a call price that is below the "fair price" that would otherwise obtain in a conflict transaction. In addition, some possible discount rules (for example, a simple charter provision proclaiming "discounts are (or are not) to be applied in fair valuations") would not perform the task of reducing the uncertainty de-

156 See Ronald J. Gilson \& Reinier H. Kraakman, The Mechanisms of Market Efficiency, 70 VA. L. REv. 549, 574-76 (1984) (explaining the existence and logic of this "'weak' learning from prices").

${ }^{157}$ See Lucian Arye Bebchuk, Freedom of Contract and the Corporation: An Essay on the Mandatory Role of Corporate Law 56 (Aug. 1988) (Program in Law and Economics Discussion Paper No. 46, Harvard Law School) (on file with author).

158 This is true even if market pricing is perfect, because in order to price a new variation, prospective investors would need to understand not only the new rule, but the old rule as well, in order to separate the price effect of the old rule from the other factors that make up current market prices.

159 See Fred LIPMAN, GoING PUBLIC 59 (1997) ("Road shows (including one-on-one meetings with institutional investors) are usually hectic."); id. at 165 (describing Microsoft's IPO road show as covering eight cities in ten days, including London and Edinburgh, with "every road show meeting attract[ing] a full house"). 
scribed above. Courts would be just as apt to mistakenly apply such rules as they do current rules.

\section{Signaling Effects}

In addition to traditional transaction costs, a firm adopting a new discount term would have to anticipate and counter any indirect "signals" that the new rule might send to prospective (and existing) investors. ${ }^{160}$ In traditional economic theory, agents engage in "signaling" behavior to counteract the problem of adverse selection: ${ }^{161}$ if principals cannot distinguish between good and bad agents because of information asymmetries, good agents may have an incentive to engage in certain activities to signal their quality. ${ }^{162}$

Here, however, the signals sent by a new discount rule may be neutral or perverse. To see this, divide firms into two categories: those who contract for a discount rule ("discount firms") and those who contract for a "nodiscount" rule ("no-discount firms"). Ex ante, investors would reasonably infer that insiders of discount firms expect to engage in a freeze-out because they believe either that (a) the firm will earn above-market rents or (b) they can expropriate value from outside investors by manipulating the timing of the freeze-out. Even if investors believe that insiders expect above-market rents, this will be a neutral and not a positive signal because investors will expect the firm to engage in a freeze-out at a discounted price, thereby "capping" the upside on their investment. ${ }^{163}$

${ }^{160}$ On signaling effects under conditions of uncertainty generally, see LOUIS PHIIPS, THE ECONOMCS OF IMPERFECT INFORMATION (1988), and Tim S. Campbell \& William A. Kracaw, Information Production, Market Signaling, and the Theory of Financial Intermediation, 35 J. FIN. 863, 881 (1980), concluding that "there will generally not be a Rational Expectations equilibrium for the asset market and the market for information."

161 See George A. Akerlof, The Market for "Lemons": Quality Uncertainty and the Market Mechanism, 84 Q.J. ECON. 488, $493-95$ (1970) (discussing adverse selection and the use of "signals" to combat its occurrence).

162 See id. at 494 (giving the example of "good quality schooling" as a method of certifying natural talent).

${ }^{163}$ Cf. Paul Asquith \& David W. Mullins, Jr., Signaling with Dividends, Stock Repurchases and Equity Issues, 15 FIN. MGMT. 27, 35 \& 41-42 (1986) (describing how an increase or decrease in dividends or an equity issue acts as a signal to the market); Jeffiy M. Netter \& Mark L. Mitchell, Stock-Repurchase Announcements and Insider Transactions After the October 1987 Stock Market Crash, 18 FIN. MGMT. 84, 86-92 (1989) (asserting that after the October 19, 1987 stock market crash, a firm's repurchase announcement, even when not followed through, "generated a positive abnormal return" by signaling that the stock was undervalued). One difference between a discount rule and a stock buyback is that a buyback suggests both an expectation of above-market rents and the controlling person's inability to freeze out all public shares, with the result that minority investors can expect to share in the abovemarket rents. 
Conversely, investors would reasonably infer that insiders of "nodiscount" firms expect not to engage in a freeze-out because they believe that either (a) the firm will not outperform the market (at best it will earn a risk-adjusted market rate of return, and at worst it will earn a below-market rate of return) ${ }^{164}$ or (b) even if the firm will earn above-market returns, insiders will not desire or be able to freeze out minority shareholders to capture $100 \%$ of those returns. Ex ante, however, investors are unlikely to be able to distinguish between firms in category (a) and firms in category (b), because insiders' expectations about future returns will often be nonverifiable. Knowing this, firms in category (b) would likely refrain from adopting either a discount rule or a no-discount rule. This would, in turn, assure that only category (a) firms--firms expecting market or below-market returns-would adopt a no-discount rule. To avoid the predictable increase in their capital costs, such firms would camouflage themselves as category (b) firms by adopting no express rule on discounts. In short, silence is a pooling equilibrium.

In sum, an affirmative choice of either rule (rather than acceptance of background law) could thus reasonably be expected to send negative signals to prospective investors. This signaling analysis produces an asymmetrical outcome in that both rules-a discount rule and a no-discount rule-would produce negative or neutral signals, rather than the perhaps more intuitive result that one rule would produce a positive signal and the other a negative signal. This signaling asymmetry results from two underlying asymmetries that confront firms and investors who contract ex ante about freeze-outs. First, firms and investors have (and reasonably understand the other to have) different ("asymmetrical") and unverifiable information about the future prospects of the firm and the likelihood of a freeze-out. Second, a freezeout can only have the direct effect of reducing minority shareholders' returns-that is, a freeze-out functions like a call option, giving the firm the right to force the investor to sell minority shares to the firm, but the absence of a freeze-out does not give the investor an equivalent ("symmetrical") "put" option that would allow the investor to force the firm to purchase mi-

${ }^{164}$ New equity issues have been interpreted as providing a similar signal. See, e.g., Robert A. Korajczyk et al., The Effect of Information Releases on the Pricing and Timing of Equity Issues, 4 REV. FIN. STUD. 685, 688-92 (1992) (asserting that firms with private positive information are more inclined to issue new equity after an information release rather than to dilute existing shareholders' value by selling at a lower price to account for market information asymmetry, but that firms without positive private information always issue without delay because they can only suffer a loss from information release); Ronald W. Masulis \& Ashok N. Korwar, Seasoned Equity Offerings, 15 J. FIN. ECON. 91, 99-117 (1986) (concluding that primary and combination stock offers generally cause a significant decrease in stock value). 
nority shares. ${ }^{165}$ Finally, it should be noted that even if an issuing firm could counteract the signaling effects described above, for example by giving plausible alternative explanations for its rule choice, it would incur (traditional transaction) costs in doing so.

\section{Summary of Transaction Costs}

To review, one possible answer to the discount puzzle is provided by transaction cost analysis. A well-marketed enforceable rule regarding discounts could be expected to reduce uncertainty and limit the ability of firms and investors to engage in opportunistic behavior. But implementing a clear discount rule would entail transaction costs that, in the aggregate, may outweigh the value of such a rule. ${ }^{166}$

\section{Externalities}

A second potential answer to the discount puzzle is that firms that contract around discount rules would encounter "network" and "innovation" externalities. ${ }^{167}$ Network externalities are positive externalities that provide

${ }^{165}$ As discussed infra, in Part IV, freeze-outs may indirectly have positive effects on minority shares (for example, by facilitating a synergy-producing merger), but the direct effects of a freeze-out are negative in the same way that the existence of a call option on a given share of stock reduces its value. The issuance of options on a class of stock may increase the value of the stock as a class by improving liquidity, but individual shares subject to the option are generally worth less than shares not so encumbered.

166 The transaction cost hypothesis may be testable, at least in most respects. It would seem possible to gather data regarding: out-of-pocket costs of drafting novel or unusual provisions to corporate charters or newly issued securities, the incidence and costs of related litigation (as compared to firms without the provisions), the incidence and costs of conflict transactions that must be revised or abandoned as a result of unclear discount rules, and the direct, marginal costs of marketing securities with such provisions. It may also be possible to gauge the impact of such provisions on a firm's cost of capital and investors' long-term returns on such securities. More subtle costs may be difficult to measure, such as costs associated with uncertain enforceability, or the anticipation and counteraction of mistaken signals of unusual contract terms.

167 See Marcel Kahan \& Michael Klausner, Path Dependence in Corporate Contracting: Increasing Returns, Herd Behavior and Cognitive Biases, 74 WASH. U. L.Q. 347, 353-58 (1996) (asserting that network externalities often prompt lawyers to utilize standard terms in contracts even when they expect that the customized term would be more beneficial; because a lawyer's reputation is based on the success of the contracts he or she drafts, the lawyer acting in a risk averse manner will be inclined to use terms that courts have properly validated or interpreted); Marcel Kahan, The Qualified Case Against Mandatory Terms in Bonds, 89 Nw. U. L. REV. 565, 598-600 (1995) (describing how the innovation externality hampers the development of novel legal terms in bonds, and how whenever lawyers, accountants, or investment bankers create new terms to overcome existing deficiencies, other companies can freeride and incorporate the new term in their bonds); Michael Klausner, Corporations, Corporate Law, and Networks of Contracts, 81 VA. L. REV. 757, 789-825 (1995) (discussing how a sub- 
users of standard contract terms with benefits over and above those that arise directly out of the terms themselves. Such externalities thus lead contracting parties to adopt standard terms even when they may be suboptimal for their particular purposes. ${ }^{168}$ Innovation externalities are a type of positive externality that provides benefits to third parties by permitting them to free-ride on the efforts of an innovating firm, and thus preventing an innovating firm from capturing the full benefits of its efforts. Each type of externality may constrain firms and prevent them from adopting innovative charter provisions or the like in an effort to contract around default discount rules. ${ }^{169}$

Network externalities depend upon future use by third parties of the same standard terms. ${ }^{170}$ One way to look at network externalities in the

optimal market equilibrium may be achieved when network externalities cause a "disjunction between market equilibrium and social optimality"). Kahan and Klausner sketch ideas for why standard terms may be suboptimal, and why firms and investors perpetuate such terms despite their suboptimality, including agency costs (particularly arising out of the attorney/client relationship), risk aversion by lawyers, herd behavior caused by asymmetric effects of innovation on firms, attorneys, and investors, and-echoing Melvin Aron Eisenberg, The Limits of Cognition and the Limits of Contract, 47 STAN. L. REV. 211 (1995)-cognitive biases arising from observed systematic irrational patterns in human behavior. See generally Kahan \& Klausner, supra (discussing the factors leading to standardization of contract terms). Although, as Kahan and Klausner note, these ideas remain in need of empirical testing, many ring true from a practitioner's perspective. For a survey of the psychological and experimental economic research on biases and heuristics, see generally John Conlisk, Why Bounded Rationality?, 34 J. ECON. LITERATURE 669 (1996).

${ }^{168}$ Kahan and Klausner identify a third type of externality-learning externalities-that may explain the survival of suboptimal standard contract terms. Learning externalities are essentially the past aspect of network externalities: externalities generated by past users of a contract term and enjoyed by future users. See Kahan \& Klausner, supra note 167, at 351. The difference between network externalities and learning externalities would not appear significant in analyzing discount rules because existing discount rules provide an essentially identical set of externalities from past and probably ongoing use.

${ }^{169}$ In addition to the evidence collected by the articles cited supra note 167, the network externalities hypothesis is supported by recent market experience for firms with dual-class capitalizations. Traditionally, such capital structures resulted in a significant pricing penalty, a result that could be explained by the comparative absence of network externalities. More recently, as the number of companies with such structures has grown, the market for dualclass stocks has improved markedly, consistent with the network externalities hypothesis. See Stephen I. Glover \& Doretha M. VanSlyke, Raising Capital and Retaining Control: Initial Public Offerings by Companies with Dual Class Common Stock, 10 INSIGHTS 18 (1996), available in WESTLAW, 10 No. 6 Insights 18; E.S. Browning, As Hot New Issues Increase So Does Supervoting Stock, WALL ST. J., Apr. 24, 1996, at C1 (describing the recent trend of companies issuing dual-class stocks in an effort to raise money without sharing power).

${ }^{70}$ In addition to the examples given in the text, Kahan and Klausner identify avoidance of formulation errors and ease in drafting as additional types of learning externalities. See Kahan \& Klausner, supra note 167 , at 350 . For the difference between learning externalities and network externalities, see Akerlof, supra note 161. For current discount rules, neither of 
context of discount rules is to consider an important set of marketing costs-transaction costs that result from contracting around existing discount rules. If only one firm were to issue redeemable common stock, it would bear all of the marketing costs associated with the stock, from educating investors about current rules to anticipating and counteracting potential signals that investors might mistakenly take away from the novel security. By contrast, if the issuing firm were part of a network of firms, all of which issued redeemable common stock, it would benefit from all of the firms' respective efforts to "spread the word" about the merits of the security. This will create more investors who are familiar with the security and who are less likely to be daunted by the fact that it varies from existing law. Lawyers will be more familiar with the new security and will provide better advice regarding potential securities law issues, at a lower cost, to issuing firms and investors alike. Enforcement costs will be lower, as more courts will produce more decisions establishing the legality of such provisions. In short, network externalities make standard terms more attractive than novel terms.

Network externalities run from other users to the users of a standard term, enhancing the value of the standard term. Innovation externalities, by contrast, run from the user of a new term to other, later users of the new term, and so decrease the (potential) value of the new term to the first user. Contractual terms - such as those in innovative securities-generally do not enjoy copyright or trademark protection, nor can they be kept confidential by public firms. Thus, innovators cannot capture the full benefits provided by such terms. Third parties can free-ride on the costly efforts of earlier innovators. ${ }^{171}$ For example, if an issuer were able to raise a greater-thanexpected amount of capital by including a commitment to pay a nondiscounted fair price in all conflict transactions, that issuer would not receive compensation from subsequent issuers that used identical commitments to enhance their stock offerings. Moreover, subsequent issuers would benefit also from the first issuer's marketing and enforcement efforts.

These two types of externalities may help explain why few firms have attempted to contract around existing discount rules, despite their lack of clarity and their unpredictability. Firms that attempted to issue redeemable common stock would not enjoy the positive externalities provided to firms that adhere to existing discount law and also yet would fail to enjoy the full benefits of their efforts to overcome the transaction costs associated with the

these externalities would appear to be particularly important because current discount rules are not explicitly drafted, but rather have emerged from case law.

17 See supra note 154 (suggesting that even legal costs alone can be a significant cost for a first-mover developing an innovative security). 
novel issuance. Although one would expect the impact of these externalities to be marginal-after all, innovation does occur in the financial markets with some regularity, ${ }^{172}$ despite the presumptive effect of these externalities-even a marginal impact could be decisive where the transaction cost calculus is otherwise close.

\section{Overpayment by Investors}

A final explanation for the discount puzzle is that firms may already enjoy the benefits that would be associated with an express discount rule. This result could occur because investors may mistakenly take Delaware discount law, as enunciated in Cavalier Oil Corp. v. Harnett, ${ }^{173}$ at face value-that is, that no discounts are permitted-without realizing that discounts in fact have been permitted in a number of Delaware cases. ${ }^{174}$ How could investors systematically overpay for minority shares? Suppose a share of stock were worth $\$ X$ under a regime in which minority discounts were always prohibited (a "no-discount regime"). An otherwise identical share of stock would be worth $\$ X$ less $\$ Y$ under a regime in which minority discounts were always permitted (a "discount regime"), where $\$ Y$ represents the present value of the potential discount appropriately discounted for time and the possibility that a transaction at a discount never occurs. If investors believed that they were investing under a no-discount regime, but were in fact investing in a discount regime (a "pseudo-no-discount regime"), they would systematically overpay for minority shares. Because the leading Delaware case on point, Cavalier Oil, holds on its face that discounts are not required in fair value determinations, ${ }^{175}$ investors easily could perceive Delaware to be a no-discount regime, even though subsequent cases such as In re Appraisal of Shell Oil Co ${ }^{176}$ and Salomon Bros. v. Interstate Bakeries Corp., ${ }^{177}$ permit discounts to be included.

If the overpayment hypothesis is true, corporate issuers and their controlling persons could benefit from incorporating in a state with a pseudo-

172 See, e.g., John D. Finnerty, An Overview of Corporate Securities Innovation, 4 J. APPLIED CORP. FN. 23, 23 (1992) (discussing "the rapid pace of securities innovation over the past two decades"); Tom Pratt, Goldman Stages Comeback in Hot "Trust Mips" Sector, INVESTMENT DEALERS' DIG., July 24, 1995, at 9 (describing rapid imitation of monthly income preferred shares ("Mips"), an innovative securities product).

173564 A.2d 1137 (Del. 1989).

174 See infra notes $176-77$ and accompanying text for Delaware cases that have permitted discounts.

${ }^{175}$ See Cavalier Oil, 564 A.2d at 1144 ("In [fair value] determination[s] the Court . . is not required to apply ... discounts.").

176607 A.2d 1213 (Del. 1992).

177 Civ. A. No. 10054, 1992 WL 94367 (Del. Ch. May 4, 1992). 
no-discount rule regime. Companies would benefit from the misperception of operating under a no-discount regime when raising equity capital. To raise requisite capital, companies in such a regime could sell shares at $\$ X$, thereby issuing fewer shares than would be the case under a discount regime in which they could only sell shares at $\$ X-\$ Y$. Reducing the number of shares issued would reduce dilution to controlling shareholders. At the time of a conflict transaction, however, companies and controlling shareholders would be able to effect the transaction at a price reflecting a discount, thus reducing the amount of cash needed to freeze out minority shareholders.

The overpayment hypothesis is in tension with the EMH. The semistrong EMH posits that market prices reflect all public information. ${ }^{178}$ If the overpayment hypothesis is true, market prices of companies in pseudo-nodiscount regimes would be systematically higher than they would be if investors correctly understood relevant law on discounts. In that case, market prices could not be said to reflect currently available information.

True, the underlying Delaware cases analyzed in Part I are available and public. ${ }^{179}$ What is not so clear, however, is whether the case law or the analysis itself should be viewed as "public information" in the sense used in the semi-strong form of the EMH-in other words, is the analysis or the case law reflected in particular stock prices? That Delaware courts have permitted implicit minority discounts to be applied in some cases is not a novel observation, ${ }^{180}$ but, as discussed below, neither does it appear to be generally known. ${ }^{181}$ One aspect of the EMH that has not been well analyzed (at least in legal literature) is how such quasi-public facts should be understood in relation to market prices.

Part of what seems to be missing is a model of how new facts are assimilated by market participants. Conventional discourse generally seems to assume an accretive, item-by-item informational model in which the full implications of a new fact, for example, a new case decision, are quickly recognized and reflected in market prices. Yet this model seems at odds not only with intuitive understandings about how people understand the world, but also with decision cost theory. ${ }^{182}$ It is more plausible that diffusion of

178 See William K.S. Wang, Some Arguments That the Stock Market Is Not Efficient, 19 U.C. DAVIS L. REV. 341, 341-42 (1986) (explaining that under the semi-strong EMH, "prices 'fully reflect' all publicly available information" (citations omitted)).

179 See cases discussed supra notes 28-34.

180 See, e.g., Hamermesh, supra note 88, at. 862.

181 See infra note 190 and accompanying text (discussing the absence of reported cases on discounts).

${ }^{182}$ See, e.g., André De Palma et al., Rational Choice Under an Imperfect Ability to Choose, 84 AM. ECON. REV. 419, 421-34 (1994) (discussing the details and deficiencies of the ways in which people process information in making choices); George W. Evans \& Garey 
complex information and its incorporation into stock prices are often gradual processes. ${ }^{183}$ As with case law generally, inconsistencies in Delaware discount law are revealed slowly: the authoritative Delaware Supreme Court speaks on an issue once a decade and the Chancery Courts once a year or so. Furthermore, inconsistencies are veiled by judicial reluctance to appear to be violating the principle of stare decisis, a reluctance anticipated and enabled by shrewd litigants. Inconsistencies are also veiled by suboptimal litigation strategies of less-than-shrewd litigants and by the factintensive nature of valuation disputes. Given this slow revelation process, it seems at least possible, a priori, that complex legal facts such as the existence of pseudo-no-discount regimes may fall into the former, but not the latter, category. In that case, the overpayment hypothesis may be consistent with a more nuanced version of the semi-strong $\mathrm{EMH}$, at least as a historical matter.

For some, the possibility that the overpayment hypothesis is at odds with semi-strong EMH may be enough to eliminate it as a persuasive explanation for the discount puzzle. ${ }^{184}$ For others, the overpayment hypothesis may ring true precisely because it would be another example why the semistrong EMH itself is unpersuasive. ${ }^{185}$ Without attempting to resolve the de-

Ramey, Expectation Calculation and Macroeconomic Dynamics, 82 AM. ECON. REV. 207, 207 (1992) (discussing the research and time costs of calculations).

${ }^{183} C f$. SARAH Fisher Ellison \& WALlace P. MULLIN, GRADUAL INCORPORATION OF INFORMATION INTO STOCK PRICES: EMPIRICAL STRATEGIES, Abstract (National Bureau of Econ. Research Working Paper No. 6218, 1997) (noting the possibility of gradual diffusion of information as successive disclosures about the same "event" reduces uncertainty, and also noting the possibility of the gradual incorporation into prices of information disclosed to multiple traders given liquidity constraints); Craig W. Holden \& Avanidhar Subrahmanyam, Long-Lived Private Information and Imperfect Competition, 47 J. FIN. 247 (1992) (discussing the gradual incorporation into prices of private information disclosed to multiple traders given heterogeneous signals or risk-aversion); Albert S. Kyle, Continuous Auctions and Insider Trading, 53 ECONOMETRICA 1315 (1985) (discussing the gradual incorporation into prices of private information disclosed to a single informed trader).

184 Commentators who affirm the semi-strong EMH include Brealey \& Myers, supra note 82, who discuss the validity of the EMH; Daniel R. Fischel, Efficient Capital Market Theory, the Market for Corporate Control, and the Regulation of Cash Tender Offers, 57 TEX. L. REV. 1 (1978), who discusses the growing support for the efficient capital market theory; and Joel Seligman, Reappraising the Appraisal Remedy, 52 GEO. WASH. L. REV. 829, 837-38 (1984), who acknowledges the "widely recognized validity of the semi-strong form" of the efficient market hypothesis.

${ }^{185}$ The semi-strong EMH is not a consensus view. See Jeffrey N. Gordon \& Lewis A. Kornhauser, Efficient Markets, Costly Information, and Securities Research, 60 N.Y.U. L. REV. 761, 786-97 (1985) (reviewing finance literature and suggesting that capital markets may not be "semi-strong" efficient); Donald L. Langevoort, Theories, Assumptions, and Securities Regulation: Market Efficiency Revisited, 140 U. PA. L. REv. 851, 912-20 (1992) (concluding that the efficiency of capital markets is unresolved); Stephen F. LeRoy, Efficient Capital Markets and Martingales, 27 J. ECON. LITERATURE 1583 (1989) (collecting studies 
bate over the semi-strong $\mathrm{EMH}^{186} \mathrm{I}$ will note simply that the overpayment hypothesis is supported by two sets of evidence: (1) the lack of adequate disclosure regarding discount law and (2) the failure of the courts or commentators to analyze discount law adequately.

Disclosure regarding minority discounts-even in jurisdictions in which discounts are or may be legal-is almost nonexistent. Many prospectuses altogether omit discussion regarding how fair value will be determined in appraisal and entire-fairness cases. ${ }^{187}$ Although the SEC appears to have

showing that market prices are frequently imperfect); Wang, supra note 178, at 375 (offering evidence that capital markets are not efficient).

186 The overpayment hypothesis might be testable. The overpayment hypothesis would imply that, ceteris paribus, minority shares of firms in pseudo-no-discount regimes would underperform shares of stocks in both discount regimes and no-discount regimes. Assume a fixed no-discount fair value at $T=1$ of $V$ per share, and that a minority discount (if legal) would be $D V$ per share (where $0<D<I$ ). In a conflict transaction at $T=1$, minority investors would receive $(1-D) V$ in both discount and pseudo-no-discount regimes, and receive $V$ in nodiscount regimes. To determine the initial required payment to issuing firms at $T=0$, apply a discount factor to payments at $T=1$ by an amount equal to $k$ (where $0<k<1$ ), which is a composite of time value, firm risk, and market risk, none of which are affected by rules on discounts. In a no-discount regime, total retum would be $R_{I}=V-k V$ and return on investment would be $R O I_{1}=R_{1} / \mathrm{kV}$ or $V / \mathrm{kV}-1$; in a discount regime, $R_{2}=(1-D) V-(1-D) k V$ and $R O I_{2}=$ $R_{2} /(1-D) k V$; and in a pseudo-no-discount regime, $R_{3}=(1-D) V-k V$ and $R O I_{3}=R_{3} /(I-D) k V$. Substituting for $R, R O I_{l}$ and $R O I_{2}$ both equal $1 / k-1$, but $R O I_{3}=1 / k-l-D / k$. In other words, regardless of $V$ or $D$, and holding $k$ constant across regimes, the total return on investment in a pseudo-discount-regime will, ceteris paribus, be less than in either a discount regime or a nodiscount regime.

This result depends upon two assumptions: first, that minority discounts as applied would be the same in both pseudo-no-discount regimes and discount regimes; and second, that the required return on investment (but for the type of discount regime) would be unaffected by which type of discount regime is chosen. If these two assumptions hold, the overpayment hypothesis-which, as noted above, proposes that market prices do not reflect the true nature of discount rules in a pseudo-no-discount regime-would imply that investors could achieve excess returns by shorting the stocks of firms in such regimes and hedging those shorts with stocks of comparable firms in discount and/or no-discount regimes. Designing a study to test the overpayment hypothesis may be difficult, however, because of the limited number of jurisdictions with clear discount rules of any sort, and because there may be confounding factors (such as other rules of corporate law) that vary with discount rules.

${ }^{187}$ Each of the principal forms established by the SEC for the registration of securities under the Securities Act of 1933 (Forms S-1, S-2, and S-3) requires the registration statement and prospectus to include (or incorporate by reference) the description specified in Item 202 of Regulation S-K of the securities being registered. Item 202 of Regulation S-K requires disclosure of a number of specific characteristics of capital stock, including "any restriction on alienability of the securities to be registered" and "any provision discriminating against any existing or prospective holder of such securities as a result of such security holder owning a substantial amount of securities." 17 C.F.R. $§ 229.202$ (a)(1) (1998). Neither provision would appear to require a description of basic corporate law providing for (or prohibiting) discounts in fair value determinations which could not be fairly described as a "restriction on alienability" and do not discriminate against substantial security holders, but against small security holders. 
included a general comment requesting disclosure of how fair value will be determined (or how fair value might relate to the merger consideration) on its checklist of targeted disclosure regarding fair value, even in connection with appraisal-triggering transactions reviews of stock merger proxy statements/prospectuses, ${ }^{188}$ disclosure remains spotty and vague. Furthermore, discussion of discounts is absent altogether. ${ }^{189}$

The absence of reported cases on discounts in over a third of the states, ${ }^{190}$ coupled with the fact that discounts can have a major impact on fair value, suggests that the issue remains completely unknown to a large segment of the bar and (because the bar is an essential link between law-

Thus, prospectuses for public offerings of common stock generally omit discussions of appraisal rights entirely. See, e.g., Keebler Foods Co., Common Stock Prospectus 1 (Jan. 29, 1998) (omitting a discussion of appraisal rights); VeriSign Inc., Common Stock Prospectus 1 (Jan. 29, 1998) (omitting a description of appraisal rights in descriptive common stock); Lucent Technologies Inc., Common Stock Prospectus 89 (Apr. 4, 1996) (omitting a discussion of appraisal rights in the description of common stock). Similarly, descriptions of common stock filed on Form 8-K under the Securities Exchange Act of 1934 also omit discussions of appraisal rights. See, e.g., Norwest Corp., Form 8-K 2 (Apr. 30, 1996).

188 See SEC Staff Comment Letters 1-3 (on file with author) (requesting disclosure of the law on how fair value will be determined in appraisal in the section of a proxy statement/prospectus comparing merging companies' shareholder rights); $c f$. SEC Staff Comment Letters 4-10 (on file with author) (failing to request a disclosure of the law on how fair value will be determined in appraisal in the section of a proxy statement/prospectus comparing merging companies' shareholder rights).

${ }^{189}$ See, e.g., Syntellect, Inc., Proxy Statement/Prospectus $41-43$ (Feb. 9, 1996) (on file with author) (omitting a discussion of discounts in a description of appraisal rights under Georgia law, the Georgia courts having ruled that discounts must be included in determining fair value); Larizza Industries, Inc., Proxy Statement 23-24 (Dec. 1, 1995) (on file with author) (omitting a discussion of discounts in the description of appraisal rights under Ohio law, the Ohio courts having ruled that discounts must be included in determining fair value); First Union/First Fidelity, Joint Proxy Statement/Prospectus 53-54 (Sept. 5, 1995) (on file with author) (omitting a discussion of discounts in the description of appraisal rights under New Jersey law, the courts of New Jersey not having ruled on discounts).

190 The question of discounts is not a new one. The first reported decision in which the issue was litigated appears to be Felder v. Anderson, Clayton \& Co., 159 A.2d 278, 285 (Del. Ch. 1960), accepting a marketability discount in the calculation of a multiplier. The issue, however, has gone unlitigated in approximately 20 states, including Alabama, Alaska, Florida, Hawaii, Idaho, Louisiana, Michigan, Montana, Nevada, New Hampshire, New Jersey, North Carolina, Pennsylvania, South Carolina, South Dakota, Texas, Utah, Virginia, West Virginia, and Wisconsin. See infra Appendix A. In some of these states (such as New Jersey, Pennsylvania, and South Carolina), there are a significant number of appraisal and entire faimess cases. See, e.g., Berger v. Berger, 592 A.2d 321, 327 (N.J. Super. Ct. Ch. Div. 1991) (deciding an appraisal case under New Jersey law); Bache \& Co. v. General Instrument Corp., 180 A.2d 535, 541 (N.J. Super. Ct. App. Div. 1962) (same); In re Glosser Bros., Inc., 555 A.2d 129, 129 (Pa. Super. Ct. 1989) (deciding an appraisal case under Pennsylvania law); In re Jones \& Laughlin Steel Corp., 477 A.2d 527, 527 (Pa. Super. Ct. 1984) (same); Defender Properties, Inc. v. Doby, 415 S.E.2d 383, 384 (S.C. 1992) (deciding an appraisal case under South Carolina law); Hite v. Thomas \& Howard Co., 409 S.E.2d 340, 343-44 (S.C. 1991) (same), overruled in part by Huntley v. Young , 462 S.E.2d 860 (S.C. 1995). 
makers and the financial markets) to the investing public. Corporate practitioners and academics are often unaware of the topic, and generally unaware of specific state rules regarding minority discounts, except in the area of tax law. ${ }^{191}$ Leading finance texts do not even address the possibility of a wedge between the value of control shares and minority shares. ${ }^{192}$ Shareholder expectations can only be confused by the split among the states on the topic. ${ }^{193}$

\section{E. Summary-Discount Puzzle}

In summary, the overpayment hypothesis, the transaction cost hypothesis, and the externality hypothesis are possible answers to the discount puzzle. Each suggested answer is tentative and in need of empirical testing. Collectively, however, they provide plausible reasons for why firms may not have been spurred to contract around current discount rules, even though they are objectionably obscure. At the minimum, they suggest that current discount rules need a second look, and that courts and commentators should attempt to provide a more predictable, policy-driven framework for firms and investors. Part IV begins that task.

\section{WHAT SHOULD DisCOUNT LAW BE?}

In this Part, I take up the policy questions that discounts raise: What should the rule on discounts be? Should the rule exclude discounts in setting fair value, as Delaware purports to do (a "no-discount rule"), or should the rule include discounts, as is done in other jurisdictions (a "discount rule")? Should the rule be a binding rule or an avoidable rule?

191 See, e.g., CLARK, supra note 80, at 443-58 (omitting a discussion of discounts in relation to appraisal rights); EASTERBROOK \& FISCHEL, supra note 22, at 145-61 (same); GILSON \& BLACK, supra note 73, at 698-702, 1268, 1305 (same).

192 See, e.g., BREALEY \& MYERS, supra note 82, at 59-62, 113-25 (failing to discuss minority discounts in a section detailing the valuation of stocks and a section on discounting generally).

${ }^{193}$ See infra Appendix A. Even courts that agree on discounts disagree on the underlying analysis. Compare Cavalier Oil Corp. v. Harnett, 564 A.2d 1137, 1144-45 (Del. 1989) (rejecting minority discounts on the basis of the pro rata value doctrine), with Brown v. Allied Corrugated Box Co., 154 Cal. Rptr. 170, 176 (Cal. 1979) (rejecting minority discounts on the rationale that minority shares in closely held corporations are not necessarily worth less to a controlling shareholder). Courts in different states that have modeled their corporate codes on one another have disagreed on the issue of discounts. Compare Friedman v. Beway Realty Corp., 661 N.E.2d 972, 977 (N.Y. 1995) (holding that discounting dissenting shareholders' shares based on their minority status would conflict with principles of corporate governance because it would deprive those shareholders of their interests in the going concem), with Atlantic States Constr., Inc. v. Beavers, 314 S.E.2d 245, 248, 250-51 (Ga. Ct. App. 1984) (considering minority discounts as a valid factor in weighing a stock's value and noting that Georgia's statute is modeled on the New York Business Corporation Law). 
Legal policy questions can be answered only by reference (explicitly or implicitly) to one or more criteria for evaluating and choosing among possible rules. I first take up the policy questions raised by discounts, primarily by using efficiency as a criterion. In spite of claims that efficiency has triumphed as a criterion in law generally or in corporate law specifically, ${ }^{194}$ courts and commentators that have addressed discounts have most frequently used (by implication) two types of criteria not directly related to efficiency: (1) rules should be fair, and (2) rules should be feasible to enforce. ${ }^{195}$ Although I conclude that neither of the non-efficiency based arguments adds to the analysis, I will examine them in turn.

Throughout the discussion, I assume that whatever rule is chosen will be mandatory and binding because, consistent with my analysis in Part II, the costs of contracting around the rule would be less than the benefits of contracting for an alternative rule. ${ }^{196}$ I also assume, consistent with my analysis in Part I.D, that the distinction between minority discounts and control premiums can and will be made-that is, that courts in setting fair value do not face the dilemma of, on the one hand, including (full) control premiums or, on the other hand, including minority discounts. Throughout this Part, I also assume that other aspects of law and practice relevant to conflict transactions remain unchanged, such as the practical difficulties with appraisal, the role of courts in determining fair value, the language of the DGCL, the costs associated with varying from default rules of corporate law, and the relative efficiency of the securities markets.

My conclusion, though tentative, is that a rule against discounts is best. $^{197}$ The theoretical analysis concludes that discounts have complicated, offsetting effects on social welfare, and that neither a no-discount rule nor a

194 See EASTERBROOK \& FISCHEL, supra note 22, at vii (noting that "corporate law has economic structure ... [and] increases the wealth of all"); RICHARD A. POSNER, ECONOMIC ANALYSIS OF LAW 10-12 (2d ed. 1977) (discussing the efficiency criterion in the economic approach to law).

195 Others argue that faimess considerations often serve as proxies for efficiency analysis. See, e.g., Louis Kaplow \& Steven Shavell, Fairness Versus Welfare Economics in Normative Analysis of Law (Apr. 21, 1998) (unpublished manuscript, on file with author) (arguing that some aggregation of individual welfare should be considered in legal policy analysis rather than any reliance on fairness considerations).

${ }^{196}$ This assumption is relaxed infra Part IV.G.

197 For a rule against discounts to be meaningful, the process by which shareholders obtain fair value must work. At present, the appraisal remedy in Delaware presents shareholders with a host of deterrents in addition to an unpredictable discount law, such as unpredictable interest awards, but these problems are beyond the scope of this Article. See Barry M. Wertheimer, The Shareholders' Appraisal Remedy and How Courts Determine Fair Value, 47 DUKE L.J. 613, 702-10 (1998) (discussing flaws in appraisal statutes and proposing various changes in existing appraisal statutes to better achieve the purpose of protecting minority shareholders). 
discount rule is clearly better. In the face of ambiguous theoretical arguments for and against discounts, I review the empirical evidence. Although limited, the existing evidence supports a no-discount rule. Next, I briefly consider whether my conclusions as to what the discount rule should be would change if the rule on discounts were a nonbinding default rule, and conclude that such a variation would only add to the arguments in favor of a rule excluding discounts. Finally, I consider arguments that the rule on discounts should be converted from an avoidable rule (as under current law) to a binding rule. I conclude that whatever discount rule is chosen, it should remain a nonbinding rule.

\section{A. What Are the Costs of Conflict Transactions?}

All things equal, a discount rule will increase the number of conflict transactions. If discounts are permitted, a given conflict transaction such as a freeze-out will be more attractive to control shareholders, and vice versa. Moreover, evidence cited in Part I suggests that discounts can have a large marginal effect on the prices paid in conflict transactions-up to $35 \%$ or more of the total price paid ${ }^{198}$ - which in turn suggests that any rule will have a large marginal impact on the number of conflict transactions undertaken. As a result, policy analysis of discount law will track closely analysis of the law on conflict transactions. A brief survey of the literature on freeze-outs and $\mathrm{MBOs}$, illustrated by a stylized example drawn from realworld transactions, indicates that conflict transactions can impose significant costs on society. I extend and update that literature with an application of economic analysis of asymmetric information that identifies previously unrecognized social costs of conflict transactions. Finally, I consider whether either discount rule would have any other significant effects on efficiency.

\section{Traditional Social Costs: Rent-Seeking}

The traditional literature on freeze-outs and MBOs begins by focusing on ways fiduciaries can, in anticipation of a conflict transaction, alter (1) apparent firm value ("value distortions") and (2) actual firm value ("valuereducing actions"). Doing so enables fiduciaries to transfer wealth from minority shareholders to themselves. Where firm value is only apparently reduced prior to a freeze-out, the transfer is immediate because the freezeout takes place at a price below the price at which investors expected ex

198 See supra note 39 and accompanying text (noting the typical range of discount percentage values). 
ante freeze-outs could occur (and thus below the price that investors used to determine the price at which they would invest in the firm). Where firm value is actually reduced, fiduciaries directly share the loss with minority shareholders, but may indirectly benefit in at least three ways: (1) by benefiting in some capacity other than as shareholder from the value-reduction, (2) by reducing firm value in a way that harms minority shareholders more than it harms fiduciaries, or (3) by reversing the value loss after the freezeout. Again, minority shareholders invest ex ante on the expectation that fiduciaries will act so as to increase firm value and (except in ways that are fully disclosed and understood ex ante) to share in the firm's gains and losses. With either value distortions or value reductions, the net effect of a freeze-out is to transfer value from minority shareholders to fiduciaries.

Fiduciaries may reduce apparent firm value by distorting the information about the firm or its prospects that is available to minority shareholders, to markets, or to courts. Such distortions can be legal or illegal and can involve blocking the flow of positive material information or the release of false or misleading negative material information. ${ }^{199}$ Illegal value distortions can occur because legal mechanisms to detect and punish (and thus deter) deception by control persons are far from perfect. ${ }^{200}$ Because there is often no public market for a target company's securities following a freezeout, the market will often not provide a useful measurement device for testing whether a freeze-out was unfairly profitable to control persons. ${ }^{201}$

199 See supra note 80 (discussing examples of lawful and unlawful blockages of information).

${ }^{200}$ Cf. Mark Hirschey, Mergers, Buyouts and Fakeouts, 76 AM. ECON. REV. 317, 318

(1986) ("Outside detection of managerial . . . self-dealing is made difficult by the fact that the same forces that provide incentives for ... fraud in the management of a firm's assets provide incentives for self-dealing in the management of information."); Burton G. Malkiel, Efficient Market Hypothesis, in THE NEW PALGRAVE: THE WORLD OF ECONOMICS 211, 215 (John Eatwell et al. eds., 1991) ("[]]nsiders trading on such information can clearly profit prior to making the announcement, as has been documented ....").

${ }^{20}$ In a recent article advocating setting fair value in buyouts of large companies equal to market price, Benjamin Hermalin and Alan Schwartz assume that market price will equal pro rata value, such that minority discounts do not exist, an assumption contradicted by empirical evidence and common sense. See supra note 38 . They also claim that value distortions and value-reducing actions are prohibited by law and unlikely to occur because post-buyout market prices will reflect gains by control persons in the buyout. See Benjamin Hermalin \& Alan Schwartz, Buyouts in Large Companies, 25 J. LEGAL STUD. 351, 366 (1996) (discussing how the appraisal price should be established). Both claims are false. Hermalin and Schwartz also claim that their analysis is based on the semi-strong form of EMH; however, except in rare instances, the groups most likely to possess material nonpublic information are management and controlling shareholders, and, if, as Hermalin and Schwartz claim, fiduciaries will disclose any such information, market prices should generally reflect all information known to any market participant, which is the strong form of the EMH. See Malkiel, supra note 200, at 215. 
Because of what may be viewed as flaws in the securities disclosure laws, control persons may have information that is "material," in the sense that disclosure would affect price, but which nonetheless has often been deemed not material by the courts as a matter of law, such as projections and other "soft" information. ${ }^{202}$ Control persons may, but need not, affirmatively mislead the market-they can simply possess material nonpublic information about the current value of the firm. ${ }^{203}$ An example would be the expected benefits of advertising, something notoriously difficult to value in many instances, yet which can reduce dramatically current period earnings and cash flows. As Robert Clark pointed out almost a decade ago, insiders may also possess information that, on an individual item-by-item basis, is not material, yet which is collectively material. ${ }^{204}$ Even if discovered, it would be difficult for law enforcers to prove that individually immaterial items of information were intentionally withheld. ${ }^{205}$

${ }^{202}$ See, e.g., Howing Co. v. Nationwide Corp., [1989-1990 Transfer Binder] Fed. Sec. L. Rep. (CCH) ๆ 94,858, at 94,656 (S.D. Ohio 1989) (holding that the defendant's acceptance of a price set by an independent investment banker was not a breach of fiduciary duty to the minority shareholder); Coyne v. MSL Indus., Fed. Sec. L. Rep. (CCH) I 95,451, at 99,284 (N.D. Ill. 1976) (noting that the SEC guidelines do not require issuers of securities to disclose their projections); see also JAMES D. COX ET AL., SECURITIES REGULATION 75 (1991) ("[T]here is no duty to disclose soft information, even ... [if] material."). Neither the proxy rules nor Rule $13 \mathrm{e}-3$ contain line items requiring disclosure of projections. Cf. Going Private Transactions by Public Companies or Their Affiliates, Securities Act Release No. 33-6101, 17 SEC Docket 1471 (Aug. 14, 1979) (proposing a projection disclosure requirement, a proposal that never was adopted).

203 Although withholding material nonpublic information under Rules $10 \mathrm{~b}-5,14 \mathrm{a}-9$, or $13 \mathrm{e}-3$ in connection with insider trading is just as illegal as making an affirmative misrepresentation ("disclose or abstain"), passive deception through nondisclosure is harder to detect and punish.

${ }^{204}$ See CLARK, supra note 80, at 507-08 (noting that insiders may have exposure to bits of information that individually are not important enough to be material but which can be valuable when aggregated).

${ }^{205}$ Congress and the courts have altered dramatically private litigation sanctions in recent years. Although it may be too early to say for certain, the provisions of the Private Securities Litigation Reform Act of 1995 and the Securities Litigation Uniform Standards Act of 1998 together appear to reduce the threat of shareholder suits as a means of detecting and punishing deceptions. See Harvey L. Pitt et al., Living with Securities Litigation Reform: Lessons from the Initial Litigation (client memorandum Oct. 31, 1996) (on file with author) (explaining the implications of the Private Securities Litigation Reform Act for the process of litigating private claims under the federal securities laws); Gibson, Dunn \& Crutcher LLP, Securities Litigation Uniform Standards Act of 1998 (client memorandum, Nov. 17, 1998) (on file with author) (discussing the key provisions of the Securities Litigation Uniform Standards Act and the reason Congress enacted the law). Likewise, class action settlement procedures that enable corporate defendants to pay off class counsel in exchange for a global settlement of securities claims make detection even less likely. See Marcel Kahan \& Linda Silberman, Matsushita and Beyond: The Role of State Courts in Class Actions Involving Exclusive Federal Claims, 1996 SUP. CT. REV. 219, 247-48 (discussing the benefits of global settlement of securities claims). 
Fiduciaries may reduce actual firm value in numerous ways without fear of legal penalty. For example, they may underinvest in net present value projects such as information systems, research and development, or acquisitions; they may invest in value-destroying projects; and they may simply shirk ordinary managerial responsibilities. ${ }^{206}$ Although valuereducing actions in theory should give rise to liability under standard fiduciary principles embedded in corporate law, the business judgment rule protects fiduciaries from judicial second-guessing of nearly any ordinary business decision, short of gross negligence or apparent conflict of interest. ${ }^{207}$ It is true that value-reducing actions will also reduce the value of the fiduciary's stake in the firm. Value-reducing transactions, however, may produce both direct and indirect offsetting gains to fiduciaries.

Direct benefits result from repeated small instances of self-dealing, perks, or above-market compensation, which although theoretically subject to a strict fiduciary standard and close judicial scrutiny, nevertheless can be undertaken with impunity if kept small and hidden. Further direct benefits result from the simple shirking of managerial responsibilities, which reduce firm value but free up fiduciaries to focus on profitable activities outside the partially owned firm, directly for themselves or through a $100 \%$-owned venture.

Indirect benefits result from value-reducing actions if the profit realized by the control person following the freeze-out is reduced by less than the fiduciary's proportionate share of the pre-freeze-out value reduction. ${ }^{208}$ In

206 Hermalin and Schwartz claim that value-reducing actions must be reversible to benefit control shareholders, but this argument is flawed because it assumes that the post-buyout value will be affected equally by the pre-buyout value reduction, and because it assumes that the value-reducing action cannot produce any immediate, offsetting gain to the fiduciary. See supra note 201. Both assumptions are unwarranted, as detailed in the text. See infra text accompanying notes 208-10.

207 See BLOCK ET AL., supra note 24, at 3-4 (explaining the business judgment rule).

208 Assume the firm (a subsidiary) is worth $\$ 100$; the parent company has a $50 \%$ stake worth $\$ 50$, and could earn $\$ 60$ by freezing out minority shareholders for $\$ 50$, for a profit of $\$ 10$. (To motivate this assumption, suppose that the parent and the subsidiary operate separate computer systems, and eliminating the subsidiary's system will cut operating costs with a present value of $\$ 10$.) Now assume the parent can reduce subsidiary value by $\$ 10$, to $\$ 90$. (Suppose the present value to the subsidiary of the subsidiary's system on a stand-alone basis is $\$ 15$, but the parent causes the subsidiary to sell it to a third party for $\$ 5$, in anticipation of combining the two firms' systems.) Finally, assume this reduction only reduces expected earnings to the control person from the freeze-out by $\$ 4$ to $\$ 56$. (Suppose the parent's system can be reconfigured to handle all operations for both the parent and the subsidiary at a cost of $\$ 4$.) Now the freeze-out would require payment to minority shareholders of $\$ 45$ ( $\$ 90$ less the parent's stake of $50 \% \times \$ 90=\$ 45$ ), producing a net profit of $\$ 11$.

Nonproportional effects could be expected whenever synergy value exceeds feasible anticipatory value destruction. Companies with underemployed assets such as natural resources might produce large profits relative to firm value. Suppose a subsidiary has underutilized for- 
fact, a nonlinear relationship between firm value and the value of the control person's proportionate share of the firm may be expected whenever the assets controlled by the firm are more valuable to the control person than in the next-highest-valued use--in other words, where synergy value exists. A parent firm and its controlled, but partially publicly held, subsidiary may have made firm-specific investments that are most valuable in combination. ${ }^{209}$ The parent company could reduce the value of the controlled subsidiary in ways that do not impact the value of the firm-specific investments or the composite rents they create. This would reduce the value of the controlled subsidiary without proportionately reducing the value of the parent's controlling stake in the subsidiary.

Finally, some value-reducing actions may be reversible, permitting a fiduciary to recapture any pre-freeze-out loss after the freeze-out. For example, a firm could retain excess cash flow and hold it in liquid, low-returning securities; delay collection of accounts receivable; or underinvest in capital equipment. If the market understood these actions as temporary, reversible actions, market prices for the firm would not fall because the market would anticipate the reversal and restoration of the firm to full value. But if the control person's actions created the expectation that the actions would not be reversed or would be exacerbated, market prices for the firm's stock would fall. The control person could then engage in a freeze-out at a lower price, reverse the value-reducing action, and realize a net gain. ${ }^{210}$

est assets worth $\$ 100$; the parent can better use the forests in its lumber operations, for synergies of \$10; pre-freeze-out, the parent causes a subsidiary to buy vehicles to transport logs to the parent's sawmills; the trucks destroy $\$ 10$ of value at the subsidiary level, where they mostly sit idle; but once used by the parent represent a net cost to the combined company of only $\$ 4$ (by reducing out-sourcing costs).

209 In other words, there exist "composite rents." See Armen A. Alchian, Rent, in THE NEW PALGRAVE: THE WORLD OF ECONOMICS, supra note 200, at 591, 593. A stylized but real-world example of such a parent/subsidiary relationship is discussed below. See infra Part IV.A.2.

${ }^{210}$ Even Frank Easterbrook and Daniel Fischel, who generally favor control transactions whether or not they involve a conflict of interest, acknowledge the possibility that looting occurs and that insiders may use inside information to pursue conflict transactions at less than pro rata value. They too, however, claim that the risk has been "exaggerated" and that doing so is "hard." EASTERBROOK \& FISCHEL, supra note 22, at 115-16, 129-31, 138. To support their claim, they argue that freeze-outs "almost always require the shareholders to vote." Id. at 138. This argument is simply inaccurate: numerous freeze-outs have been accomplished by short-form merger preceded by control acquisitions, all without a shareholder vote. See 1 LIPTON \& STEINBERGER, supra note 2, § 9.03(2), at 9-13. Fleet Financial Group's 1994 acquisition of Fleet Mortgage was such a transaction. See Fleet Financial Group, Inc., Offer to Purchase (Jan. 30, 1995), supra note 19. The largest conflict transaction in 1996-the Levi Strauss buyout-did not require a shareholder vote. See Levi Strauss Assocs. Inc., Schedule 13E-3 (Feb. 14, 1996), supra note 1. Easterbrook and Fischel also claim that conflict transactions frequently trigger competing bids and an auction, driving up prices and preventing control persons from pushing through a "sweetheart" deal. See EASTERBROOK \& FISCHEL, supra 


\section{Wealth Transfers: A Real-World Example}

Value distortions and value-reducing actions often work in tandem, and can be subtle and hard to discover in the real world of uncertainty and asymmetric information, notwithstanding the federal securities laws. To illustrate wealth transfers in the conflict transaction setting, a hypotheticalstylized for exposition but based on several different, real-world transactions-is useful, illustrated in Figure 1.

note 22 , at 138 (commenting that the delay in effecting a freeze-out often allows any "inside" information to be revealed, thus eliminating any advantage the insiders had and often resulting in higher bids for the firm). Although this analysis may be true of many MBOs, it does not apply to parent/subsidiary freeze-outs, or going private transactions sponsored by a controlling family shareholder group (like the Levi Strauss deal), where a preexisting control block will deter competitors from making more than nominal efforts to bust up the deal. See Chazen, supra note 33, at 1443-59 (discussing acquisitions by controlling shareholders and how they may eliminate competing bids by refusing to sell their shares). 
Figure 1.

Pre-Merger
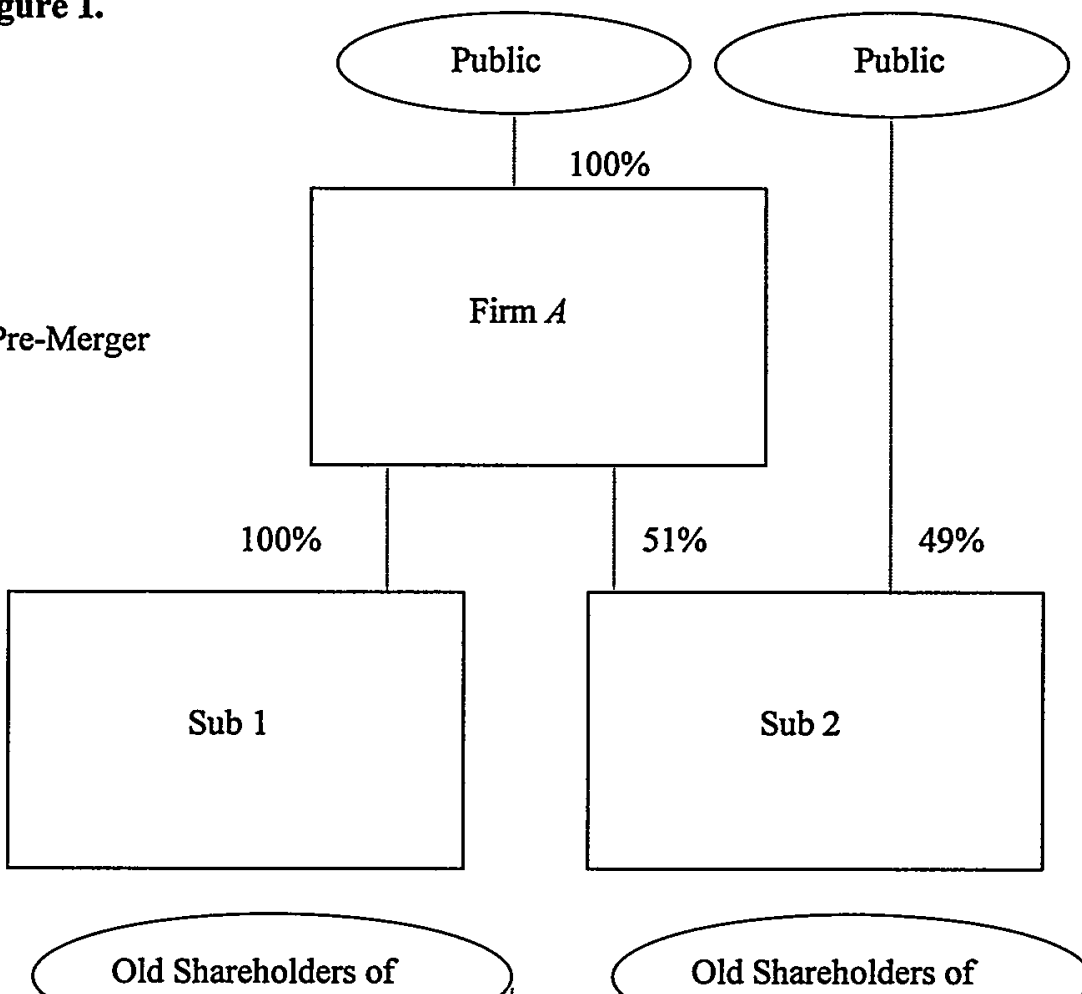

Firm $A$

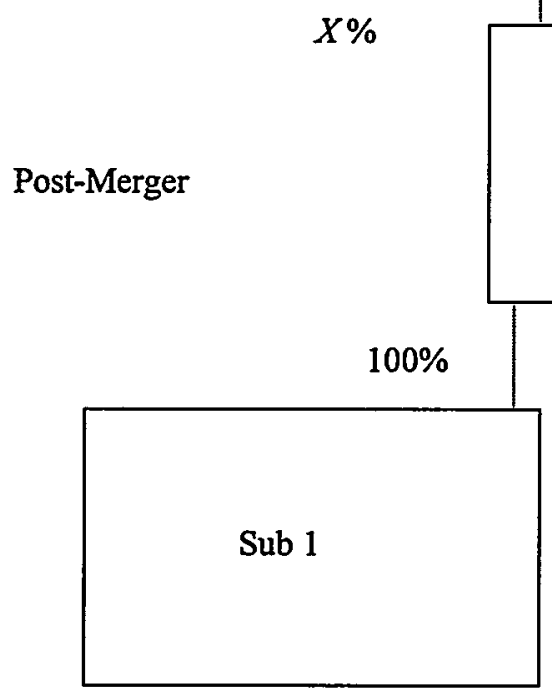

Firm $A$

Old Shareholders of Sub 2 $Y \%$ 
Firm $A$ is a large public company. Firm $A$ owns $100 \%$ of Sub 1 and $51 \%$ of Sub 2, with the minority interest held by the public. Firms Sub 1 and Sub 2 are middle-market firms in Industry $X$. Sub 1 and Sub 2 might operate in different geographic areas, or might be managed by teams engaged in a parent-sponsored "tournament" for promotion designed to reduce monitoring costs. ${ }^{211}$

Firm $A$ underinvests in Sub 1, which is then forced to underinvest in a technology that is increasingly important for providing value-added services to customers in Industry $X$. Sub 2 is permitted to use free cash flow to make net present value investments in such technology. Over time, the actual value of Sub 1 erodes relative to Sub 2 because of Sub 1's underinvestment in technology. Public investors are unable to detect the erosion of value in Sub 1, because Sub 1 has no direct financial reporting obligations and represents an immaterial portion of Firm $A$ 's assets, so that Firm $A$ does not (and is not required to) break out separate information about Sub 1 in Firm $A$ 's own financial reports.

Ongoing changes in Industry $X$ lead Firm $A$ to anticipate-two years in advance-that merging Subs 1 and 2 will result in synergies, for example, from the shared creation and use of information technologies, or from federal deregulation that can be expected to create a nationwide market in Industry $X$. Firm $A$ begins to take a hard look at Sub 2's financial statements in advance of their quarterly publication. Accounting rules permit some flexibility when certain types of revenues (and related earnings) in Industry $X$ are reported, and Firm $A$ causes Sub 2's reported earnings during the premerger period to erode relative to industry peers and to Sub 1 , but this erosion is based solely on changes in accounting policies that are not sufficiently material to clearly require separate disclosure. ${ }^{212}$ Firm $A$ also uses its control over Sub 2 to veto net present value projects that Sub 2 proposes, with a view toward implementing those projects after the merger.

Firm $A$ now causes Sub 2 to acquire Sub 1, using Sub 2 stock as consideration. Firm $A$ is able to transfer value from Sub 2 minority shareholders to itself in the merger in two ways: (1) by setting an exchange ratio that

211 For a discussion of toumament theory, see generally HAROLD DEMSETZ, THE ECONOMICS OF THE BUSNESS FIRM 110-36 (1995).

212 See HowaRd M. SCHILIT, FINANCIAL SHENANIGANS 6 (1993) ("[]t is surprisingly easy for managers to use accounting gimmicks to manipulate financial statements ... [because] (1) [t]here is substantial flexibility in interpreting [Generally Accepted Accounting Principles ("GAAP")], (2) GAAP can be applied to boost a company's reported profits, and (3) changes to GAAP by the Financial Accounting Standards Board ... often occur long after a deficiency in financial reporting becomes evident."); see also Kinney \& Trezevant, supra note 80 , at $45-48$ (discussing how studies of accounting data suggest that firms use discretion afforded under accounting rules to "manage" earnings). 
overvalues Sub 1, and (2) by setting an exchange ratio that undervalues Sub 2. Under Delaware law and SEC rules, Sub 2 shareholders would be provided with historic and pro forma financial information about both Sub 1 and Sub 2 (but not necessarily projections of synergies), but Firm $A$ can effectively overvalue Sub 1 by affirmatively overstating its historic earnings, by presenting its historical data on an apples-to-apples basis with Sub 2's historic data, and by omitting to disclose Sub 1's past underinvestment in technology. Because of these value distortions, outside investors would value Sub 1 by applying a similar multiple to the earnings (or cash flows) as applied to Sub 2, despite the relative actual lower quality of Sub 1's prospects. Firm $A$ could also undervalue Sub 2 by failing to disclose the recent accounting policy changes and delayed investments in net present value projects.

After the merger, Firm $A$ will be able to reverse the effects of Sub 2's accounting policy changes and (most of) the effect of Sub 2's delayed investments ("reversal benefits"), and offset any residual loss with the synergies of combining Sub 1 and Sub 2. In a stock merger of Sub 1 and Sub 2, the reversal benefits and synergies would be shared, of course, with minority shareholders of Sub 2, due to their ongoing interest in Sub 2, but the minority shareholders' share of the synergies would be reduced by the other value transfers built into the merger. Moreover, the presence of synergy values would disguise the capture of the reversal benefits, and reduce the already low likelihood of effective minority shareholder litigation challenge. If the conflict transaction were a simple cash freeze-out of Sub 2 shareholders, the size of the transfers and the unlikelihood of an effective litigation challenge would be even more pronounced, for there would be no sharing of reversal benefits or synergies, and there would be no ongoing public reporting at the level of the combined Sub 1 to provide outside investors with information to suggest that the freeze-out had occurred at an unfair price.

\section{Conflict Transactions Are Nonconsensual and Largely Unconstrained}

Economic theory often presumes that, absent market failure, private transactions are socially optimal because they are consensual. In many if not most conflict transactions, however, shareholders do not "consent" in any sense, theoretical or practical, to the transaction. In the hypothetical above, for example, minority shareholders of Sub 2 would have no practical ability to veto the transaction. As a result, the standard inference drawn about market transactions-that they are Pareto improvements because the parties to the transaction value what they get more than what they have given up-cannot be made. Even in those transactions in which shareholders are given the right to veto a transaction, well known free-rider problems 
undermine any inference that widely dispersed shareholders place a higher value on the consideration received than the stock given up. ${ }^{213}$

It is true that, as described in Part I, shareholders have a right to have a court review a conflict transaction to make sure that minority shareholders receive fair value in the transaction. In the hypothetical above, for example, minority shareholders of Sub 2 would have the right to challenge the entire fairness of the merger as a conflict transaction. 214 The same free-rider problems that undermine the usefulness of a shareholder vote, however, also undermine the practicality of judicial policing of conflict transactions. Appraisal rights, in particular, suffer from numerous procedural problems, perhaps the most significant of which is that plaintiff-shareholders cannot count on receiving a market rate of interest ${ }^{215}$ during the pendency of cases that can take over ten years to litigate. ${ }^{216}$ Even when shareholders pursue judicial remedies, and even when rules on discounts are clear and respected, it is far from certain that fiduciaries will not be able to convince a court to accept a proposed firm value that is well below true firm value, however measured. At best, shareholders' threat of legal protection prevents wealth transfers from exceeding fairly generous bounds.

Likewise, reputation at best will constrain controlling shareholders and managers only from extreme forms of expropriation in conflict transactions, and only when future participation in the capital or labor markets is expected. Reputation, too, is crucially dependent on the effectiveness of legal remedies: to the degree those remedies fail, outside investors will anticipate that fiduciaries will benefit more from a given wealth transfer than from having a good reputation, which accordingly will reduce the benefit that otherwise might have flowed from a good reputation. Finally, and ironically, in some situations a fiduciary's good reputation may have the perverse effect of discouraging the investigation of or legal challenge to a given

213 See Gordon, supra note 123 , at $1575-77$ (discussing rational apathy in the shareholder voting context).

214 Minority shareholders would not have appraisal rights in a stock merger of Sub 1 and Sub 2, but would have appraisal rights in a cash freeze-out of Sub 1 shareholders. See DEL. CODE ANN. tit. 8, \& 262(a), (b), (d) (1991 \& Supp. 1996) ("Any stockholder ... who holds shares of stock on the date of the making of a demand pursuant to [a merger or consolidation other than a stock merger pursuant to $\S 251(\mathrm{~g})]$... who has neither voted in favor of the merger or consolidation nor consented thereto ... shall be entitled to an appraisal by the Court of Chancery of the fair value of [the stockholder's] shares of stock. ...").

215 See, e.g., Rapid-American Corp. v. Harris, 603 A.2d 796, 808 (Del. 1992) (upholding the trial court's grant of simple interest, and refusing to adopt guidelines for when trial courts should award market rates of interest).

${ }^{216}$ See, e.g., Cede \& Co. v. Technicolor, Inc., 684 A.2d 289, 290-91 (Del. 1996) (recounting the 12-year procedural history of the litigation). 
conflict transaction, even if the transaction involves a clear wealth transfer from minority shareholders.

\section{Ex Post Social Costs of Pure Wealth Transfers}

Conflict transactions allow fiduciaries to transfer wealth to themselves from minority shareholders. From some perspectives, that may be enough to suggest that they are not socially optimal and should be discouraged. No conflict transaction that involves a wealth transfer of the sort described above could be expected to be Pareto optimal, because minority shareholders were better off prior to the transaction (and prior to the value-reducing actions that the transaction induced) than afterwards. ${ }^{217}$

But from other perspectives, social welfare is not thought to be directly affected by pure wealth transfers. Under the Kaldor-Hicks definition of "efficiency," social welfare is deemed improved if a transaction results in a net increase in utility, with wealth functioning as the usual proxy for utility. ${ }^{218}$ A pure transfer from minority shareholders to fiduciaries would be irrelevant to social welfare from this perspective. Presumably, investors would either reduce ex ante share prices sufficiently to compensate for the transfers, or decline to invest altogether. A firm that engages in a freeze-out at some point after it issues stock to the public will, all other things being equal, provide a lower return to "frozen out" investors than a firm that does not. This is because shareholders who were frozen-out cease to earn a return on their shares after a fixed period of time, whereas shareholders of firms that do not engage in freeze-outs continue to earn above-market returns. ${ }^{219}$ But in a world of perfect information and certainty, a firm that later would engage in a freeze-out would, at the time of stock issuance, simply pay a higher price for its equity capital than other firms. The difference exactly matches the correspondingly lower return to equity investors. Alternatively, as Frank Easterbrook and Daniel Fischel have argued, conflict transactions are like lotteries, and wealth transfers from investors to fiduci-

217 See ROBERT COOTER \& THOMAS ULEN, LAW AND ECONOMICS 12 (2d ed. 1997) (discussing Pareto efficiency).

${ }^{218}$ See POSNER, supra note 194, at 10-14 (addressing the shortcomings of the Paretian tradition of economic analysis); $c f$. COOTER \& ULEN, supra note 217 , at $41-42$ (contrasting Pareto efficiency with Kaldor-Hicks efficiency).

${ }^{219}$ To the extent that a publicly held firm earns below-market returns, it is a matter of indifference to investors that the firm never engages in a freeze-out, because investors in such firms can always sell their shares on the market, thereby obtaining the same liquidity that a freeze-out by such a firm would provide. 
aries are of little concern because investors will gain as often as they will lose. 220

Given that at least some conflict transactions are socially beneficial, as discussed in Part IV.B below, the initial implication of the Kaldor-Hicks view of efficiency (and of the lottery analogy) is that conflict transactions should be encouraged. Even from a Kaldor-Hicks perspective, however, conflict transactions nevertheless may reduce social welfare ex post in two ways. First, the value taken from minority shareholders may exceed the value received by the fiduciaries because of differences in valuation, due to heterogeneous information or preferences. ${ }^{221}$ Second, and more straightforwardly, the value taken from minority shareholders may exceed the value received by the fiduciaries even where shareholders value stock equally, because conflict transactions necessarily entail transaction costs. Conflict transactions in this traditional view are simply a costly form of rent-seeking.

For example, freeze-outs inevitably give rise to legal and investment banker fees, printing, mailing, and other procedural expenses, and the loss of sunk accounting and systems costs. Even for arm's-length transactions, such costs can be significant. Moreover, fees in conflict transactions (as a percentage of the total deal value) exceed those in arm's-length transactions, because of the litigation and reputation risks associated with transactions that by definition involve conflicts of interest. For a typical $\$ 1$ billion freeze-out, legal and investment banking fees alone can exceed $\$ 20$ million. ${ }^{222}$ Although not as large, mailing and printing costs associated with proxy or information statements and shareholder notices often exceed $\$ 100,000 .^{223}$ Freeze-outs also impose other costs directly on minority shareholders-taxes can be a significant expense, and aggregate reinvestment expenses may not be trivial. ${ }^{24}$

In addition to out-of-pocket costs, conflict transactions involve opportunity costs. In the above hypothetical, for example, management of all three firms-Firm A, Sub 1, and Sub 2-would need to invest substantial

220 See EASTERBROOK \& FISCHEL, supra note 22, at 122, 121-23 ("[T] here is a strongly negative correlation among the risks [in a conflict transaction]. An investor with a reasonably diversified portfolio would be on the winning side of some transactions and the losing side of others.").

221 See CLARK, supra note 80, at 505-06 (discussing the possibility of different subjective valuations); Stout, supra note 74, at 1245, 1244-52 ("The assumption of homogeneous beliefs is at odds with a reality in which investors and analysts differ sharply in their predictions for particular corporations, industries, and the general economy.").

222 See, e.g., QVC Programming Holdings, Inc., Offer to Purchase, supra note 2 (noting legal and banker fees of $\$ 20$ million).

223 See, e.g., id. at 50 (noting printing and mailing fees of $\$ 200,000$ ).

224 See Toms, supra note 85, at 569 (discussing the tax costs of freeze-outs); see also CLARK, supra note 80, at 504-05 (discussing both taxes and reinvestment expenses). 
amounts of time to plan and implement the merger of Sub 1 and Sub 2. Experience reveals that directors and senior management will spend a minimum of 100 hours each, and often much more, on a major conflict transaction, and each such transaction will involve upwards of a dozen senior managers and directors. Although that may not sound that large, consider that certain senior executives in recent years have been receiving compensation that would value that time in the millions of dollars for each executive. Presumably, that time otherwise could be put to socially productive use.

In sum, because conflict transactions may involve pure wealth transfers that do not increase social wealth and involve significant ex post transaction costs, they may reduce social welfare, even under a Kaldor-Hicks criterion. ${ }^{225}$

\section{Ex Ante Social Costs of Conflict Transactions}

In addition to the ex post social costs of conflict transactions, such transactions can be expected to have ex ante social costs. In a world of uncertainty and asymmetric information, the ability of controlling shareholders to engage in conflict transactions creates a distortion in the allocation of capital. Permitting conflict transactions to be completed with minority discounts included in setting fair value will increase that distortion, and so reduce social welfare.

To see this, imagine that firms issuing stock in the public capital markets for the first time are of two types: firms that will engage in a freeze-out at some future date ("freeze-out firms") and those that will not ("non-freezeout firms"). Assume that investors are rational and risk neutral, and that the

225 The focus of the text is on allocational efficiency. Pure wealth transfers might also implicate distributional concerns. As a general matter, minority shareholders as a group will include a greater percentage of small investors with proportionately less wealth than either of the groups that benefit from transfers in conflict transactions (controlling shareholders and managers). "Small investor" in this context, however, is an unclear term. High net worth individual investors, for example, comprise a significant portion of shareholders who hold the smallest amount of assets, relative to institutional shareholders. Likewise, widows and orphans dependent on capital invested through trusts, traditionally thought to need the protection of the securities laws the most, often fall into the richest one percent of the U.S. population. By contrast, mutual funds and pension funds are large investors in the ordinary sense of things, yet represent indirectly (and imperfectly) the interests of individuals who lack sufficient wealth to invest directly in the stock market. Even if the concept of small investor corresponded in some general way with relatively impoverished individuals, small investors are increasingly likely to hold a diversified portfolio of investments, and may to that extent benefit from conflict transactions, as suggested by Easterbrook and Fischel's lottery analogy. See supra note 220 and accompanying text. In the hypothetical above, for example, Firm A could be expected to have a large number of shareholders who. directly or indirectly, represent small investors as well as large investors. 
capital markets are semi-strong efficient, but that investors are unable to tell whether a given firm is a freeze-out firm or a non-freeze-out firm. ${ }^{226}$ Firms of both types will face the same cost of capital, which will reflect the average probability of a freeze-out across all firms. Because freeze-out firms will, ceteris paribus, provide lower returns to investors than non-freeze-out firms, non-freeze-out firms will, in effect, subsidize freeze-out firms. Such a cross-subsidy represents a distortion in the allocation of capital, and reduces social welfare.

To the extent that minority discounts are permitted in freeze-outs, they only will increase the effect of this subsidy, for two reasons. First, minority discounts will reduce the average returns to investors in all firms by reducing the price paid in freeze-outs; and second, minority discounts will reduce the average returns to investors in all firms by increasing the number of freeze-outs that occur-a minority discount increases the attractiveness of a freeze-out to a controlling shareholder, ceteris paribus.

This cross-subsidy may be exacerbated by an adverse selection problem, depending on the relationship at any given time between the cost of capital in the public and private capital markets. For some subset of nonfreeze-out firms, at various points in time, the cost of capital in the private capital market may fall below the average cost of capital for all firms in the public capital market, causing such non-freeze-out firms to exit the public capital market altogether. This will cause the remaining firms raising capital in the public markets that are freeze-out firms to increase, thereby increasing the average cost of capital for firms continuing to raise funds in the public capital markets. It is true that the costs of capital in the public and private equity capital markets are related; if the spread between public and private equity capital costs sufficiently widens to cover transaction costs, an arbitrage opportunity will be created and exploited, eventually reducing the spread. Still, transaction costs of arbitrage between public and private capital markets are never zero, and the persistent cyclicality of the merger and IPO markets suggests that disparities necessary for the sort of adverse selection problem described to exist may occur with some regularity.

Whether or not this adverse selection problem occurs, it is clear that the cost of capital for non-freeze-out firms will increase, both as the number of freeze-outs increases and the price paid in freeze-outs decreases. As the

${ }^{226}$ This is a reasonable assumption given that the attractiveness of a freeze-out at any moment in time depends upon a range of factors, many of which are in constant fluctuation, including the relative cost of capital in the public and private capital markets. In practice, even the firms themselves rarely will know their own type with any degree of certainty at the time of stock issuance and so will have neither an obligation to disclose nor a likelihood of disclosing their type to potential investors. 
cost of capital increases, fewer firms will be able to raise capital, and fewer projects requiring capital investment will be undertaken.

The cross-subsidy effects may be viewed from the perspective of the investor as well. If the average return to investors of all firms falls below a certain level, a subset of investors may withdraw from the equity markets altogether. In either case, gains from trade are lost. Without an offsetting benefit, freeze-outs and other conflict transactions can be expected to reduce social welfare, not only because of the ex post transaction costs associated with pure wealth transfers, but also because of the ex ante effects such transactions cause in a world of uncertainty and asymmetric information.

\section{B. Why Permit Conflict Transactions at All?}

Given the distortion caused by conflict transactions, why not prohibit conflict transactions altogether? The literature on freeze-outs and MBOs provides several answers. ${ }^{227}$ Conflict transactions can be expected to enhance social welfare by encouraging entrepreneurs to search for valueincreasing transactions, by reducing the incentives to "lock-in" minority investments, and by eliminating the risk of hold-ups by minority shareholders that would enhance the market for corporate control. Including discounts in fair value will, on the margin, increase the number of such transactions without reducing the related benefits and so enhance social welfare.

The most common rationale offered for freeze-outs is that they permit the capture of synergies that otherwise would be unavailable. As noted above, the combination of two assets in the hands of a single owner may create "synergistic" value. ${ }^{228}$ Freeze-outs permit a controlling shareholder who owns $100 \%$ of one such asset but only a controlling stake in a second asset to capture all of the synergies from the combination by first eliminating the minority owners of the second asset. ${ }^{229}$ Without freeze-outs, a controlling shareholder might use the $100 \%$ owned asset without seeking such synergies if the benefits of doing so would exceed the controlling shareholder's proportionate share in the combined assets. Lost synergies reduce social welfare to the extent that they exceed losses that the freeze-out would create.

227 See CLARK, supra note 80, at 510-12 (discussing motives for freeze-outs); 1 LIPTON \& STEINBERGER, supra note $2, \S 9.01$, at 9-3 to 9-7 (same).

${ }^{228}$ See discussion supra Part I.D.2.a (explaining the nature of synergy value and how it arises).

229 See example discussed supra Part IV.A.2 (illustrating how this type of deal creates a wealth transfer). 
In a recent article, Benjamin Hermalin and Alan Schwartz advance a second, related rationale for freeze-outs. They note that freeze-outs provide controlling shareholders with the incentive to exert socially optimal effort in pursuing new investment projects. ${ }^{230}$ They note that controlling shareholders will, on the margin, refrain from exerting above-normal effort (for example, to pursue a new project or line of business) as long as the fiduciary must bear the entire cost of effort that could be exerted on behalf of the firm, but be entitled to only part of the gain. ${ }^{231}$ In such situations, one way to induce the fiduciary to exert the socially optimal effort is to permit a freeze-out at pro rata value. Thus, conflict transactions may provide controlling shareholders with an incentive to exert optimal effort.

A third rationale for permitting freeze-outs and other conflict transactions is simply that such a transaction may represent the best exit strategy for minority shareholders, even given the risks that such transactions present. This point is clearest in the close corporation context, but has some traction even for public companies. In a close corporation, a freeze-out or other conflict transaction may be the only way minority shareholders can hope to liquidate, or for firms that are not paying current dividends, to realize any return on their investment. Ex ante, better exit strategies can be devised for minority shareholders, such as buy-sell agreements, mandatory redemption provisions, and registration rights agreements. Crafting and embodying such strategies in legal documents, however, is costly and rarely done. In such situations, minority shareholders may well be pleased to accept a freeze-out price, even one below the nominal pro rata value of their shares. In such a situation, the nonconsensual aspects of the freeze-out serve to eliminate hold-ups by one or more minority shareholders seeking to extract gains from other shareholders.

A fourth rationale for permitting freeze-outs is that they are necessary to the functioning of the market for corporate control. Hostile takeovers, MBOs, and related merger and acquisition activity usually provide target shareholders with substantial premiums above market price. As noted by Easterbrook and Fischel, second-step freeze-outs in two-step takeovers benefit minority shareholders to the extent that they include a

230 See Hermalin \& Schwartz, supra note 201, at 358 ("If the majority could not freezeout the minority, it would invest a suboptimal level of effort.").

${ }^{231}$ See id. at 359 ("[T]he majority will not invest optimally if it has to share value with the minority."). 
price that is a premium to pre-takeover market prices-even if the secondstep freeze-out price is less than the first-step tender offer price. ${ }^{232}$

A final rationale against a rule banning freeze-outs is that such a rule would be difficult to make either binding or effective. Where private benefits to a control person of a freeze-out or MBO were large, the control person could be expected to expend resources to avoid the rule, such as by combining a tender offer with a merger or asset purchase or sale with a third party and/or a liquidation. Where private benefits to a control person or $\mathrm{MBO}$ were not large enough to warrant such a maneuver, the control person would be tempted to engage in or increase the number of smaller, less visible conflict transactions to expropriate wealth from minority shareholders. Although a ban on freeze-outs might reduce total expropriation value, additional transaction costs associated with the substitute forms of self-dealing (either one large or many small transactions) would reduce social gains from the ban. Thus, it is not clear that a ban on freeze-outs would have much, if any, effect on social welfare.

\section{How Do the Costs and Benefits of Conflict Transactions Compare?}

In sum, it is unclear at the level of theory whether the benefits of conflict transactions dominate their costs. David Charny is likely correct that "predominant noninstrumental theories of contract are in large measure indeterminate as to the question of default rules." ${ }^{, 233}$ But, at least in this context, instrumental theories are equally indeterminate at the level of theory. Such a result is hardly surprising, given the inevitable complexity and intricacy of the real-world effects of any rule of corporate law, potentially affecting hundreds if not thousands of transactions, large and small, involving public companies and close corporations, start-ups and venerable multi-line businesses alike. Any attempt to weigh the costs and benefits of conflict transactions themselves would necessarily involve at least three sets of unexplored or disputed empirical questions.

First, it is far from clear how much more frequently freeze-outs would occur if discounts were permitted than if they were not. The motives, determinants, and effects of mergers and acquisitions generally are understood poorly, and the sensitivity of merger and acquisition activity to stock prices

232 See EASTERBROOK \& FISCHEL, supra note 22, at 137-38 (arguing that "[a] freezeout price above the current market price is no less beneficial to shareholders because the price was once higher').

${ }^{233}$ David Charny, Hypothetical Bargains: The Normative Structure of Contract Interpretation, 89 MICH. L. REV. 1815, 1818 (1991). 
is a poorly understood relationship. ${ }^{234}$ Even more basically, there has been surprisingly little attention given to how often freeze-outs and other conflict transactions occur. ${ }^{235}$ Even less studied is the effect that the possibility of a freeze-out has on share price at the time of an IPO, and thus how significant the effect of such a transaction may be on share price. ${ }^{236}$ Given that investors could be expected to price shares differently for freeze-out firms and non-freeze-out firms, the seriousness of the cross-subsidy is still speculative, as is the degree to which it would be exacerbated by permitting discounts.

Second, commentators have widely varying intuitions about how often fiduciaries engage in value distortions and value-reducing transactions, and about the significance of such behavior. ${ }^{237}$ Few have attempted to measure such practices empirically. ${ }^{238}$ Moreover, even if value-reducing transactions are common, some would take place regardless of whether freeze-outs were permitted. In addition, it is possible that more might take place if freezeouts were barred than if they were not. Any reduction in expropriation produced by a ban on freeze-outs would thus be offset.

234 See BREALEY \& MYERS, supra note 82, at 817-18 (arguing that the causes of mergers and merger waves are an unsolved problem in finance theory); Devra L. Golbe \& Lawrence J. White, A Time-Series Analysis of Mergers and Acquisitions in the U.S. Economy, in CORPORATE TAKEOVERS: CAUSES AND CONSEQUENCES (Alan J. Auerbach ed., 1988) (noting the puzzling relationship between Tobin's $Q$ and merger activity).

235 A review of data from MERGERSTAT REVIEW 1997, supra note 13, and data from Securities Data Co. (on file with author) shows that, of the companies in the Fortune 500 in 1985 , about $1 \%(n=6)$ were involved in freeze-outs during the ten-year period surveyed. When the universe of companies surveyed is expanded to include the smaller companies in the Russell 2000 index, the percentage of companies involved in freeze-outs during the ten-year period remains relatively small, at less than $5 \%(n=80)$. These data do not seem to cut one way or another on the social welfare effects of conflict transactions, because infrequent freeze-outs produce both small costs and small benefits.

${ }^{236}$ As a first rough cut, consider an IPO of a $\$ 1$ billion company. If the company has a $.005 \%$ chance per year of engaging in a freeze-out over the next 20 years (an assumption consistent with the data described supra note 235), then the expected cost to investors (and thus the increase in the firm's cost of capital) from a $35 \%$ discount in the freeze-out price, in present value terms (using a $10 \%$ discount rate and a terminal value of zero after 20 years for simplicity), would be approximately $1.36 \%$ of the offer price, or $\$ 13.6$ million-not large in proportion to the offer price, but still large enough to matter to the firm's agents, who might capture some of that cost if they could devise an effective strategy for avoiding it. Systemically, of course, $1.36 \%$ of all IPOs is a huge number. In 1997 alone there were 508 IPOs involving \$26 billion in new equity. See FoRBES, Year in Review, Feb. 1998.

${ }^{23}$ Compare Brudney \& Chirelstein, supra note 2, at 1354 (noting that litigation in this area has become more active), with EASTERBROOK \& FISCHEL, supra note 22, at 134-39 (countering arguments that freeze-outs distort value over the long term).

${ }^{238}$ See Andrei Shleifer \& Robert W. Vishny, A Survey of Corporate Governance, $52 \mathrm{~J}$. FIN. 737, 759 (1997) (noting the "small number" of papers measuring the extent to which expropriation occurs). 
Third, commentators also have widely varying intuitions about the significance of merger synergies generally, and freeze-out-related synergies in particular. ${ }^{239}$ Similarly, although Hermalin and Schwartz's model of the effects on the efforts of controlling persons is logically consistent, ${ }^{240}$ it is unclear whether the distortions on effort exerted by fiduciaries in the absence of complete ownership are serious or trivial. ${ }^{241}$ The liquidity and wealth constraints facing a typical minority shareholder (and thus her need to rely on freeze-outs to liquidate minority investments) are also unexplored. Finally, remaining debates from the 1980 s, such as those over the net social welfare effects of takeovers ${ }^{242}$ and the importance of freeze-outs to the market for corporate control, are far from resolved. ${ }^{243}$

Needless to say, the foregoing empirical questions are unlikely to have clear answers in the near future. Fortunately, there is another, less comprehensive but more accessible, empirical question that can serve as a proxy: What do actual bargains between market participants suggest about the relative efficiency of including or excluding discounts?

Before turning to the evidence on actual bargains, however, it is worth considering whether discount law is likely to have significant efficiency effects apart from its impact on the number and terms of conflict transactions. One possibility is that discount law might affect information costs facing investors when they value firms or securities. Initially, it might seem that a rule allowing discounts would reduce information costs by reducing the number of variables that actual or potential minority investors would need to consider in valuing minority shares. By eliminating speculation about fair value, a discount rule seems simpler and cheaper than a rule barring discounts.

This would be true, however, only if fair value were determined entirely by the market price of minority shares. One difficulty with such a rule is that stocks of many companies do not trade in liquid markets. As a result, different rules would be needed for widely traded public companies, on the

239 See Coffee, supra note 77, at 412-20 (considering which situations warrant allocation of synergistic gains between management and the corporation).

240 See generally Hermalin \& Schwartz, supra note 201 (offering a model and accompanying commentary on freeze-outs and their investment implications).

241 Cf. Coffee, supra note 77, at 408-10 (critiquing the Hermalin and Schwartz model as unrealistic).

${ }^{242}$ See generally KNIGHTS, RAIDERS, AND TARGETS (John C. Coffee, Jr. et al. eds., 1988) (providing a collection of articles on takeovers reflecting diverse views on their social welfare effects).

${ }^{243}$ Cf. EASTERBROOK \& FISCHEL, supra note 22, at 134-39 (arguing that freeze-outs enable value-enhancing transactions, but not offering any views or evidence on the size or significance of the enabled transactions). 
one hand, and public companies with limited or thin "public floats" and closely held companies, on the other. Although not impossible, such a differentiation would run roughshod over current Delaware statutory law, which distinguishes in DGCL section 342 between ordinary business corporations and nonpublic companies with fewer than thirty record holders. Thus, such a distinction would in all likelihood require legislative action.

A more serious theoretical difficulty derives from the discussion concerning pure wealth transfers-control persons may be able to distort market prices in anticipation of a freeze-out. Minority shareholders would thus have a continuing need to assess (at some cost) the value of their shares without the distortions in order to bring lawsuits under the state and federal laws governing disclosure and manipulation. That effort would be no different in kind than an effort to assess fair value determined on some basis other than minority share market prices. Thus, the information cost advantage of a rule allowing discounts is much smaller than it might first appear, if it exists at all.

\section{What Do Actual Bargains Say About Discounts?}

In the face of ambiguous, theoretical arguments for and against discounts, I review the empirical evidence on discounts. Although this evidence is limited, what does exist supports a no-discount rule, but the evidence also supports continuing to permit conflict transactions generally. Three sources of empirical evidence exist on discounts: (1) private agreements that address discounts, (2) prices paid in freeze-outs, and (3) state laws on discounts.

The bulk of publicly available charter provisions and private buy/sell agreements do not address freeze-out pricing, and of those that do, most do not address discounts. ${ }^{244}$ The few agreements that do address the question, however, show that private parties generally agree to exclude discounts and distinguish discounts from premiums, while permitting (or even requiring)

244 See infra note 245 (discussing and analyzing available data); see also PRATT ET AL., supra note 4, at 669-76 (lamenting the lack of detail in buy/sell agreements, and noting that "often ... the provision for valuation ... [in] a buy-sell agreement ... is neglected or done hastily," that parties are often surprised to learn that minority discounts may be appropriate depending on the language used, and that buy/sell agreements range from specifying nodiscount to a $50 \%$ discount); cf. Christopher Stoneman \& Willemien Dingemans Miller, Estate Planning for Owners of Closely Held Business Interests, BNA Tax Management Portfolio No. 809 (1994), at A-5 to A-6 \& B-101 to B-103 (describing customary buy/sell agreement pricing terms without addressing discounts, and giving an example of a model agreement that fails to address discounts); PETER C. KOSTANT, BUSINESS ORGANIZATIONS 141-42 (1996) (same). 
freeze-outs to occur. ${ }^{245}$ For example, when McCaw Cellular acquired LIN Broadcasting Corporation ("LIN"), the transaction contemplated an eventual buyout of the remaining LIN shareholders, and the transaction agreement dealt with the issue of how to choose a price for the buyout. ${ }^{246}$ The McCaw/LIN agreement described the minority share buyout price as "the private market price per Share (including a control premium) that an unrelated third party would pay ... to acquire all outstanding [common stock of LIN] . . . in an arm's-length transaction, assuming [LIN] was being sold in a manner designed to attract all possible participants ... and to maximize stockholder value."247

A second source of evidence regarding actual agreements are the prices paid in going private transactions and tender offers involving controlled targets. Such transactions almost always provide for payment of a premium to market prices, which reflect a minority discount, and announcements of such transactions are almost always followed by an immediate rise in the market price of the target shares. Specifically, data from Securities Data Co. on all conflict transactions $(n=1604)$ during the ten-year period from 1985 to 1996 show an average premium-to-market price of $45 \%$, shown in Figure 2 below. In all freeze-outs ${ }^{248}$ during the same period $(n=154), 90 \%$

245 I completed the following search in the Compny/Filing file in the LEXIS database (which contains all filings through SEC-Online, dating back to 1986): "(buy/sell or put/call) pre/1 agreement and minority w/5 discount." The search returned seven agreements (as well as numerous descriptions of and references to agreements), of which five expressly prohibited inclusion of minority discounts in determining the price at which one of the parties could purchase the stock of another party upon specified events (one expressly permitted a marketability discount), and two expressly required inclusion of discounts.

The filings that included agreements barring discounts were: Capital Trust, Schedule 13D, Exh. 99 (Dec. 19, 1997); McCaw International Ltd., Form S-4, Exh. 10 (July 18, 1997); United Oklahoma Bankshares Inc., Schedule 13e3, Exh. 4 (June 9, 1997); Physician Partners Inc., Form S-4 (Nov. 6, 1996); and Minnesota Power \& Light Co., Form 10-K, Exh. 10 (Mar. $30,1996)$. The filings that included agreements requiring discounts were: Realnetworks Inc., Form S-1, Exh. 10 (Oct. 1, 1997) and Pierce Leahy Corp., Form S-4, Exh. 10 (Oct. 4, 1996).

When the search is expanded to all put/call and buy/sell agreements, i.e. "(buy/sell or put/call) pre/l agreement," by contrast, over 350 agreements are returned, confirming that the vast majority of agreements do not expressly specify treatment of discounts.

These findings are consistent with my own experience that private buy/sell agreements are in the substantial majority of cases either silent on the question of discounts or specify that the buyout price will represent a pro rata share of firm value, with no discounts applied.

${ }^{246}$ See Wasserstein Perella Letter Setting Forth Determination of LIN Broadcasting Private Market Value, BUS. WIRE (Mar. 6, 1995) (publishing a letter from the appraiser designated to resolve the dispute between independent directors of LIN and LIN's parent company describing the pre-agreed upon formula for fixing the minority share buyout price).

247 Id.

248 For this purpose, I define "freeze-out" to include any cashout of minority shareholders by another shareholder with more than $30 \%$ of the relevant shares. If the definition is expanded to include management buyouts, the numbers do not change materially. 
of the transactions involved a premium-to-market of more than 5\%, and the average premium was $40 \%$. These results are confirmed by data from Mergerstat Review, which shows that the average premium paid in going private transactions in each year during the ten-year period surveyed was greater than $30 \%{ }^{249}$

\section{Table 2.}

\begin{tabular}{||l|c|c|c|}
\hline & $1987-1991$ & $1992-1996$ & $1987-1996$ \\
\hline $\begin{array}{l}\text { Conflict Transactions in All } \\
\text { Regimes (n=1604) }\end{array}$ & $49 \%$ & $43 \%$ & $45 \%$ \\
\hline $\begin{array}{l}\text { Freeze-outs in All Regimes } \\
(\mathrm{n}=154)\end{array}$ & $43 \%$ & $30 \%$ & $40 \%$ \\
\hline $\begin{array}{l}\text { Conflict Transactions in } \\
\text { Discount Regimes (n=29) }\end{array}$ & $41 \%$ & $43 \%$ & $42 \%$ \\
$\begin{array}{l}\text { Freeze-outs in Discount Regimes } \\
(\mathrm{n}=7)\end{array}$ & $51 \%$ & $47 \%$ & $49 \%$ \\
\hline
\end{tabular}

Some portion of these premiums are presumably paid to deter entire fairness litigation and appraisal cases. Even in jurisdictions that permit discounts, such as Ohio, however, sponsors of conflict transactions almost always pay premiums over market price to minority shareholders. Admittedly, sample sizes are small, but a t-test of means does not reject the hypothesis that the premiums paid in all regimes and in discount regimes are the same at a $10 \%$ significance level. Further, in discount regimes, all freeze-outs ( $n=7$ ) during the ten years from 1987 to 1996 were at premiums of greater than $5 \%$, and the average premium paid in conflict transactions in discount regimes $(n=29)$ was $43 \%$. The uniformity of such premiums suggests that an extra-legal "norm" exists and that discounts should not be imposed in conflict transactions such that even where a controlling shareholder may be legally permitted to impose discounts, they refrain from doing so, possibly out of reputation concerns. Such a norm provides further evidence that a rule excluding discounts is efficient. ${ }^{250}$

249 See MERGERSTAT REVIEW 1997, supra note 13, at 42 (listing the statistics showing the average premium paid in going private transactions over the ten-year period from 1987 to 1996).

${ }^{250}$ On occasion, reasons may exist for not enforcing extra-legal norms: secular shifts in given markets may render a norm outmoded; strategic interests of a set of participants in a given market may lead to the creation of norms that inefficiently favor those participants; and distributional concerns may outweigh efficiency reasons for enforcing a given norm. See David Charny, Illusions of a Spontaneous Order: "Norms" in Contractual Relationships, 144 
A final source of evidence about what the majority of contracting parties would choose is that a majority of issuing firms are located in jurisdictions with rules excluding discounts (at least in theory), ${ }^{251}$ and because such firms can contract around such rules but choose not to it appears possible that a rule excluding discounts is tacitly chosen by a majority of contracting parties.

Because state corporate law comes as a package-a corporation generally cannot choose to rely on Delaware law regarding takeover defenses but Ohio law regarding fair value determinations-one can only infer so much from the fact that Delaware's rule regarding discounts has not deterred a majority of public corporations from continuing to incorporate in Delaware. ${ }^{252}$ But the fact that corporations have not used their ability to contract around the law of fair value determinations by issuing redeemable shares, ${ }^{253}$ while continuing to remain subject to the remaining provisions of Delaware law, does provide some evidence about the merit of a rule rejecting discounts. ${ }^{254}$ As Roberta Romano put it, "[I]f firms routinely choose clause y

U. PA. L. REV. 1841, 1854 (1996) (noting that "commentators have long argued that the norms that ordinarily govern commercial life should not be incorporated into the legal standards for contract enforcement"); Eric A. Posner, Law, Economics, and Inefficient Norms, 144 U. PA. L. REV. 1697, 1727 (1996) (noting that "rapid economic or technological change may suggest that unchanged norms have become inefficient" and that "highly unequal endowments of group members may be evidence of inefficient norms"). I am unaware of any evidence suggesting such a counterindication exists here.

251 A majority of jurisdictions, including Delaware, California, and New York, at least purport to have rejected minority discounts. Admittedly, clear judicial rejection of minority discounts in fair value determinations is relatively recent. Only in the last 15 years has the issue been defined in a sufficiently sharp way for issuing corporations and investors to understand how courts will resolve the issue. As shown in Part I, Delaware decisions continue to suggest that minority discounts might be accepted if valuations are cleverly framed so that the discounts are implicit rather than explicit, and appear at the "corporate level" rather than at the "shareholder level." See supra Part I. The lack of viable policy analysis behind Delaware's pro rata value doctrine has caused confusion in the markets regarding the strength, certainty, and durability of the rejection.

252 See Demetrios G. Kaouris, Is Delaware Still a Haven for Incorporation?, 20 DEL. J. CORP. L. 965, 1010 (1995) (surveying new incorporations and reincorporations of companies traded over-the-counter or listed on the New York Stock Exchange, and concluding that "Delaware remains the preeminent state for incorporation").

${ }^{253}$ See supra Part II (describing ways of contracting to include or exclude discounts available to Delaware corporations).

${ }^{254}$ An immediate objection to this reasoning is that there is no evidence of corporations using redeemable shares (or some other method) in Ohio (or other states permitting discounts to be included) to contract around the rule applicable to them that requires inclusion of discounts. Hence, the evidence from observing firm behavior is inconclusive. There is some merit to this objection-the evidence adduced in this Section is not, in fact, conclusive.

Two responses, however, can be made, which together argue that the evidence of firm behavior remains persuasive (if not conclusive) that a default rule rejecting discounts is optimal. First, a far greater number of corporations that participate in the public markets incorporate in 
over clause $\mathrm{x}$, then we know from their revealed preference of picking $\mathrm{y}$ when they could have chosen $x$, that clause $x$ is suboptimal. ${ }^{255}$

\section{E. Which Discount Rule Is Fairer?}

Most courts in addressing the question of discounts have not principally used efficiency-based rationales to decide cases. Instead, they have either claimed that stare decisis applies, ${ }^{256}$ or crafted rationales that appear to be based on either fairness or feasibility criteria. Fairness-based rationales for upholding or rejecting discounts fall into either of two categories: claims of unfair surprise or claims of unequal treatment. ${ }^{257}$ These rationales fail to

states rejecting discounts than in states accepting discounts. Second, any rule regarding discounts is a special type of rule that for convenience may be called a "conflict rule." A conflict rule is one that regulates conflict transactions, and therefore will, ex post, benefit or harm control persons at the expense or gain of minority investors. Evidence that corporations have not contracted around a conflict rule that ex post benefits control persons is less suggestive than evidence that corporations have not contracted around a conflict rule that ex post harms control persons for the simple reason that control persons have the power to contractually eliminate the harm. To put it differently, redeemable shares would benefit control persons in states like Delaware, where the rule regarding discounts harms control persons, but they would harm control persons, at least ex post, in states like Ohio. Because control persons make the decision of whether to issue redeemable shares, one would expect to see more discount contracts in states like Delaware than one would in states like Ohio.

255 Roberta Romano, Answering the Wrong Question: The Tenuous Case for Mandatory Corporate Laws, 89 COLUM. L. REv. 1599, 1604 (1989).

${ }^{256}$ As noted supra Part I.D, Delaware's principal (and erroneous) rationale for rejecting minority discounts when it first faced the issue in the Cavalier Oil case was that the issue had already been decided and only applied to valuations at the corporate level. See Cavalier Oil Corp. v. Harnett, 564 A.2d 1137, 1144 (Del. 1989). Courts in other states, as well as commentators, have also appealed to legislative history in rejecting discounts, claiming that because appraisal procedures and entire fairness cases are meant to protect minority shareholders, minority discounts should be excluded because they would reduce recoveries by minority shareholders. See, e.g., Wertheimer, supra 197, at 643-44 (noting that the "primary source of the appraisal remedy today is to protect minority shareholders from wrongful conduct" and concluding that "[i]f this purpose is to be fulfilled, the dissenting shareholder must receive a pro rata share of the value of the corporation"). Although it is no doubt correct that such judicial remedies were developed primarily to protect minority shareholders, see 1 AMERICAN LAW INSTITUTE, PRINCIPLES OF CORPORATE GOVERNANCE: ANALYSIS AND RECOMMENDATIONS ch. 4 (1994) (discussing the history and purpose of appraisal), it is also true that such remedies were not meant to transfer an unlimited amount of value from control persons to minority shareholders. It is possible to accept minority discounts and still believe that appraisal rights should protect minority shareholders-by affording them a right to receive a minority share price for their shares. The relevant question is: How should fair value determinations protect minority shareholders? Legislative history is silent on that question. See id.

${ }^{257}$ Courts have articulated even less persuasive "faimess" arguments. One court argues that rejecting discounts would afford minority shareholders an unjustifiable windfall and would impose a penalty on control persons. See Armstrong v. Marathon Oil Co., 513 N.E.2d 776, 788 (Ohio 1987) (contending that rejecting discounts clearly should "not give dissenting 
provide any strong reason for Delaware courts to either reject or accept discounts, and each is briefly described and critiqued.

\section{Unfair Surprise}

Fairness arguments in the discount context are often premised on loose notions of shareholder expectations. Minority shareholders expect to be given less than controlling shareholders, because they know minority shares are worth less than control shares. Failing to include a minority discount would unfairly surprise the controlling shareholder. Conversely, shareholders expect to receive an equal share of the firm, despite being minority shareholders, because each share of stock has the same legal rights at the time of investment. Therefore, to permit a freeze-out at a minority discount would constitute unfair surprise, because most freeze-outs are at a premium to market. ${ }^{258}$ The "flippability" of the unfair surprise argument is an immediate strike against it, from either perspective. Expectations arguments can plausibly be made from either point of view, precisely because the parties did not have specific expectations based on clear disclosure or express bargaining. The argument is also vulnerable to the objection that if the choice of discount rule is clearly known at the time of investment, neither rule presents any question of unfair surprise. Finally, although surprise may indicate unfairness, lack of surprise does not indicate fairness. One expects crime, for example, but that is hardly a reason to repeal laws against theft.

shareholders any element of value attributable to the transaction from which they have dissented"). Delaware courts have made exactly the opposite arguments in favor of rejecting discounts-that accepting discounts affords control persons an unjustifiable windfall and imposes a penalty on minority shareholders. See Cavalier Oil, 564 A.2d at 1145 ("[T]o fail to accord to a minority shareholder the full proportionate value of his shares imposes a penalty for lack of control, and unfairly enriches the majority shareholders who may reap a windfall from the appraisal process by cashing out a dissenting shareholder."); see also Wertheimer, supra note 197, at 644 n.143 (quoting Cavalier Oil approvingly on this point). Because whether a discount should be termed a "penalty" or a "windfall" is decided by the same court that decides whether or not to accept or reject the discount, such terms are post hoc surplus and provide no basis for deciding one way or the other. $C f$. Cede \& Co. v. Technicolor, Inc., 684 A.2d 289, 299 (Del. 1996) (adopting the "penalty" and "windfall" phraseology from Cavalier Oil).

258 This argument should be distinguished from the argument made supra Part IV.C that the fact that premiums are routinely paid in freeze-outs, even in jurisdictions where doing so is not required, is evidence that a no-discount rule is efficient. The argument here is based simply on shareholder expectations, regardless of whether the expectations are in line with an efficient result. The argument made supra Part IV.C does not depend on any given shareholder expecting a premium, but only on the inference drawn from their being paid that an efficient, consensual norm to exclude discounts exists. 
The surprise argument for including discounts is also subject to the objection that it confuses financial discounts and legal discounts. ${ }^{259}$ The two are conceptually distinct. Although discounts in the marketplace do constitute evidence of the value of shares, courts should at least inquire as to why those discounts exist before accepting their existence as a reason for imposing a discount in a fair value determination. Minority discounts in the financial markets are caused in part by expropriation value, and, as such, simply reflect the risk, or the absence of that risk, that control persons may be able to successfully steal, defraud, or breach fiduciary duties owed to the corporation. To include discounts in freeze-outs because they exist in the markets would, as cogently stated by Victor Brudney, permit the "very existence of [a control person] and its capacity to exploit unlawfully [to] legitimize the fact of such exploitation."260

\section{Unequal Treatment}

Unequal treatment rationales for rejecting minority discounts come in both a simple and a subtle form. The simple form is reflected in a recent New York decision in which the court reasoned that, because all shares have equal rights, fair value should represent an equal share of total firm value. ${ }^{261}$ Because including minority discounts implies that minority shares are worth less than control shares, minority discounts violate the "mandate of equal treatment." ${ }^{262}$ Unfortunately, this argument begs the policy question. If shares must be treated equally in a determination of fair value, then by definition no minority discounts apply. Simply noting that minority discounts result in unequal treatment does not provide a good policy reason for rejecting them. In addition, it is a general principle of Delaware $\operatorname{law}^{263}$ (and in

259 See supra Part I.C.1 (discussing the roles of and distinctions between legal and financial discounts).

260 Brudney, supra note 80 , at 70 n.36.

261 See Friedman v. Beway Realty Corp., 661 N.E.2d 972, 976 (N.Y. 1995) ("II]n fixing fair value, courts should determine the minority shareholders' proportionate interest in the going concern value of the corporation as a whole.").

262 Id. at 977. The trial court in Beway Realty distinguished marketability discounts from minority discounts on the ground that all shares of a close corporation are equally unmarketable, and therefore a majority does not derive an unequal benefit from discounting minority shares to reflect this fact. See id. This argument is weak because, as an empirical matter, it is clear that all shares of a corporation are not equally unmarketable-at least for closely held companies, minority shares are less liquid than control shares. See PRATT ET AL., supra note 4, at 301 (Exhibit 14-1, note) ("Control shares in a privately held company may also be subject to some discount for lack of marketability, but usually not nearly as much as minority shares.").

263 See Bershad v. Curtiss-Wright Corp., 535 A.2d 840 (Del. 1987) (upholding a sale of control by a controlling shareholder under Delaware law). See generally Einer Elhauge, The 
all likelihood of New York law as well ${ }^{264}$ ) that control shareholders are entitled to sell their control shares at a premium to market without either sharing that premium with minority shareholders or structuring a transaction to ensure equal treatment of minority shareholders in the sale. ${ }^{265}$ Finally, literally applied, equal treatment would appear to require that minority shareholders receive a control premium, including synergy value and pure control value, something contrary to both Delaware and New York law. ${ }^{266}$.

The more subtle version of the unequal treatment rationale for rejecting discounts is found in California case law. California courts have reasoned that fair value should represent the value of minority shares to the control person pursuing the transaction, because in a freeze-out it is effectively the control person that is acquiring the minority shares. ${ }^{267}$ Because minority

Triggering Function of Sale of Control Doctrine, 59 U. CHI. L. REV. 1465 (1992) (discussing differing views on the duties of controlling shareholders to pay part of a premium from a sale to minority shareholders).

${ }^{264}$ See Zetlin v. Hanson Holdings, 48 N.Y.2d 684, 685 (1979) (upholding a sale of control by a controlling shareholder under New York law).

265 See Bershad, 535 A.2d at $841-42$ (rejecting the contention that a majority shareholder owes the minority shareholders a fiduciary duty to sell its stock to the highest bidder); $c f$. William D. Andrews, The Stockholder's Right to Equal Opportunity in the Sale of Shares, 78 HARV. L. REV. 505, 506 (1965) (proposing a rule requiring minority shareholders to be given the right to "tag along" with control shareholders in a sale of control).

${ }^{266}$ See In re Fleischer, 486 N.Y.S.2d 272, 274-75 (App. Div. 1985) (finding that the acquisition premium is not appropriate to consider in determining fair value); see also supra Part I.D.2 (discussing Delaware law on control premiums). The equal treatment rationale is also inconsistent with the fact that conflict transactions by definition provide control persons with a form of benefit not shared with all shareholders equally. Freeze-outs force cash on minority shareholders while control persons retain equity in the firm; minority shareholders need not receive the same form of consideration, the same tax treatment, or literally equal value, and no subsequent valuation is required to "settle up" if the stock obtained by a controlling shareholder turns out to have been worth more than the cash payment to minority shareholders in the freeze-out. See Toms, supra note 85, at 548-50 (describing disparate tax and transaction cost impacts of freeze-outs and proposing that minority shareholders be compensated for objectively ascertainable costs caused by freeze-outs, such as tax and reinvestment transaction costs). Yet freeze-outs are generally legal in Delaware and New York. See Weinberger v. UOP, Inc., 457 A.2d 701, 715 (Del. 1983) (holding that freeze-outs are not only legal, but require no business purpose); Alpert v. 28 Williams St. Corp., 473 N.E.2d 19, 24 (N.Y. 1984) (upholding a freeze-out merger).

267 See, e.g., Brown v. Allied Corrugated Box Co., 154 Cal. Rptr. 170, 176 (Ct. App. 1979) (asserting that the value of minority shares should reflect their value to the person seeking to purchase them). The Brown case arose not in an appraisal proceeding per se, but in an analogous court-supervised buyout proceeding under Califomia law. See CAL. CoRP. CODE $\S 2000$ (West 1991) (providing dissolution action procedures). Many states such as California and New York, see N.Y. BuS. CoRP. LAW $\S \S 1104,1118$ (McKinney 1986), provide minority shareholders in a close corporation with the right to dissolve the corporation on various grounds, including "oppression," "waste," or, in jurisdictions such as California, "deadlock"; and if the corporation wishes to avoid dissolution it may buy out the minority shareholders at "fair value," which again has generally been found to be the same "fair value" 
shares cease to be minority shares in the hands of the control person, they should no longer be valued as if they were subject to the risk of expropriation-a control person will not expropriate wealth from himself. Thus, in the hands of the control person, minority shares should be valued equally with all other shares.

An internal difficulty with this logic is that once a control person has obtained control, additional minority shares do not convey control. As a result, the value to a control person of additional minority shares generally will be lower than the value of control shares. Minority shares will be worth less to a control person than control shares for two reasons. First, minority shares do not bring with them additional pure control value, which the controlling shareholder already has obtained. ${ }^{268}$ Second, acquisition of minority shares eliminates expropriation value, which depends on minority shareholders for its existence. Although there may be good reasons to ignore the difference in setting fair value, it is clear that the difference exists. ${ }^{269}$ Finally, as with New York's version of the unequal rationale, California's reasoning would seem to require that fair value include a full control premium including shared merger synergies, a result that has consistently been rejected in Delaware, although not in California. ${ }^{270}$

As with unfair surprise, both forms of unequal treatment rationale fail, in the end, to offer anything more than window dressing on a conclusion already reached. New York law straightforwardly and California law indirectly beg the question. Why should minority shareholders always be entitled to the same value as controlling shareholders? One is immediately led

that arises in appraisal proceedings. See, e.g., Brown, 154 Cal. Rptr. at 176; Beway Realty Corp., 661 N.E.2d at $975-76$.

${ }^{268}$ See Sporborg v. City Specialty Stores, Inc., 123 A.2d 121, 124 (Del. Ch. 1956) (holding that a controlling shareholder's purchase of shares at a given price is not sufficient to establish a market price to consider in determining fair value using the Delaware block method, and taking "judicial notice" of the fact that majority shareholders often pay a "premium" for minority shares).

269 A survey of public company acquisitions announced during 1994 and 1995, based on data provided by Securities Data Co. Inc. (on file with author), shows that premiums paid in cash-out transactions involving independent targets averaged $39 \%$ over the target's market price four weeks prior to the announcement, compared to an average of only $33 \%$ for cash-out transactions involving controlled targets (that is, where the acquiror owned a $30+\%$ stake prior to the transaction). When the universe of transactions is expanded to include all cash tender offers for public companies announced during 1994 and 1995 (regardless of whether they were $100 \%$ cash-out transactions), the average premium paid over market price four weeks prior to the announcement increased to $53 \%$ for independent targets, compared to $35 \%$ for controlled targets. See generally PRATT ET AL., supra note 4.

270 See supra Part I.D (discussing Delaware law's rejection of minority discounts and its use solely of the going concern value to determine fair value); $c f$. Jones v. H.F. Ahmanson \& Co., 460 P.2d 464, 471 (Cal. 1969) (finding that the control shareholder must share the control premium with minority shareholders). 
to ponder what wonderful effects equal treatment would have. How would those effects compare to the harmful effects that the rule would produce: reduced synergies, distorted effort effects, lock-in of minority shareholders, and impairment of the market for corporate control? This leads back to efficiency analysis.

\section{F. Which Discount Rule Is More Feasible?}

One final category of rationales for accepting or rejecting discounts is that one rule or the other would be easier to implement from a procedural point of view. Indeed, this type of argument was made by both the Delaware Supreme Court in Cavalier Oil ${ }^{271}$ and by the American Law Institute in the Principles of Corporate Governance. ${ }^{272}$ Once again, however, the identical argument can be, and has been, advanced on behalf of a rule permitting discounts. ${ }^{273}$ Neither view is persuasive as a general matter because estimating discounts is required under either rule. If fair value is based on minority share market prices, a rule excluding discounts would require estimating the discount so as to exclude it, with attendant procedural difficulties. If fair value is based on a DCF valuation, however, as is sometimes necessary (as when market prices have been affected by takeover rumors), a rule including discounts would require fixing a discount to include the DCF valuation, thereby increasing procedural complexity. ${ }^{274}$

Using market prices as the exclusive basis for valuation would exclude a discount for private companies, but include one for public companies (unless they were the subject of takeover speculation, in which case the valuation would be at a premium). Such a rule would necessarily produce not only inconsistent rules but also perverse incentives. Private firms-precisely those companies whose synergy-driven mergers are more common and whose freeze-outs should be encouraged to enhance minority shareholder liquidity-would be discouraged from undertaking freeze-outs, be-

271 See Cavalier Oil Corp. v. Harnett, 564 A.2d 1137, 1146-47 (Del. 1989) (finding the no-discount rule easier to implement).

272 See 2 PRINCIPLES OF CORPORATE GOVERNANCE 324 (1994) ("Any ... rule [including discounts] would require the court to undertake a complicated and ultimately speculative inquiry ....").

See, e.g., Armstrong v. Marathon Oil Co., 513 N.E.2d 776, 788-91 (1987) (finding that a discount rule is "a less complicated valuation proceeding"). Hermalin and Schwartz make such an argument on behalf of using market prices as "fair value" in buyouts; however, because their analysis assumes that minority discounts do not exist, their argument really favors using a market-price-based rule, regardless of what value that produces. See Hermalin \& Schwartz, supra note 201 , at $344,367-69$.

274 See supra notes 28-34 and accompanying text (discussing valuation methods in entire fairness cases). 
cause they would be required to pay nondiscounted prices. Large public firms-precisely those companies whose incentive to take value-reducing actions or to block the flow of valuation information to the market is greatest because the potential gains are larger-would be encouraged to undertake freeze-outs because they would be required to pay only discounted prices. In addition, such a rule would allow a company to reduce its own "fair value" by selling a modest number of shares to the public and thus creating a market for its minority shares. Finally, such a rule is very unlikely to be adopted without legislative action because neither the DGCL nor Delaware case law has distinguished between public and private companies in determining fair value. ${ }^{275}$

A final feasibility argument for including discounts is that doing otherwise would give minority shareholders an incentive to pursue "fair value" through litigation rather than by selling at market value in the securities markets. ${ }^{276}$ Again, this argument only applies to public firms; minority shareholders of private firms have no market sale option and will, by necessity, bargain with controlling shareholders over a freeze-out price in the shadow of case law on fair value. Even as applied to public companies, this argument assumes that control shareholders will seek to set a freeze-out price at a discounted price and thus induce litigation. But if discount law clearly rejected discounts (both explicit and implicit), freeze-out proponents would be more likely to set a freeze-out price in line with this law precisely to avoid litigation. Indeed, freeze-out proponents already appear to be doing so. ${ }^{277}$ Finally, as is recognized, appraisal and entire fairness litigation is sufficiently unattractive to minority shareholders as a procedural matter that without other dramatic changes in appraisal law, defining "fair value" to exclude discounts is unlikely to create a large drain on judicial resources.

In sum, there is no reason to expect a no-discount rule to be more intractable for courts to apply than its opposite, nor is there any reason to expect more litigation with a no-discount rule.

275 See DEL. CODE ANN. tit. 8, § 262 (1991) (providing appraisal rights for shareholders without differentiating between public and private corporations, and stating that the special provisions governing closely held corporations do not affect fair value determinations); see also Cavalier Oil, $564 \mathrm{~A} .2 \mathrm{~d}$ at 1142-45 (discussing a fair value determination for a private company); Smith v. Shell Petroleum, Inc., No. CIV.A.8395, 1990 WL 84218, at *48 (Del. Ch. June 19, 1990) (citing and following Cavalier Oil in a fair value determination for a public company).

276 See John D. Emory, Jr., Comment, The Role of Discounts in Determining "Fair Value" Under Wisconsin's Dissenters' Rights Statutes: The Case for Discounts, 1995 WIS. L. REV. 1155, 1173 (arguing that the failure to discount shares would encourage appraisal litigation and "strain limited judicial resources").

277 See supra Part IV.D (discussing the empirical evidence that reflects this trend in freeze-out transactions). 


\section{G. Does the Default Nature of Discount Law Affect the Choice of Rule?}

The foregoing policy analysis has implicitly assumed that whatever discount rule is adopted will govern all firms in a mandatory, binding fashion. As demonstrated in Part II, however, current law allows firms to vary discount law by private contract, through redeemable common stock, through buy/sell agreements, or via other contracting mechanisms. Before addressing the policy question of whether discount law should remain nonbinding, consideration should be given to whether the fact that discount law is and perhaps should be nonbinding affects the policy choice of which discount rule should be the default rule.

Analysis here again supports a no-discount rule. As between two potential default rules, the potential costs of contracting around whichever rule is chosen should be considered. Lucian Bebchuk has argued that where a nonbinding default rule is to be chosen from two alternatives, neither of which is clearly superior, preference should be given to the rule that is less favorable to control persons, because such a rule has a better chance of being corrected over time should the rule prove inefficient. ${ }^{278}$ The "least cost" approach, then, also favors a default rule excluding discounts. Corporations are currently able to contract around rules regarding discounts by amending their charters or reincorporating. In addition, corporate managers and controlling stockholders choose the terms of the initial corporate charter and occupy the best position to effect changes in state law. If courts accept the conclusion of Part IV.H below and leave intact the largely nonbinding nature of the rule, corporate managers and controlling shareholders will be best positioned to avoid the effects of a poorly chosen rule. Thus, the rule chosen should benefit the party least able to resort to mechanisms for avoiding the rule, the minority shareholders, supporting the exclusion of minority discounts.

\section{H. Should Discount Law Be Nonmandatory?}

Before concluding, some consideration should be given to whether discount law should remain mandatory but nonbinding, whether it should be made nonmandatory, or whether it should impose constraints on the ability of firms to contract around whichever discount rule is chosen.

Firms compete for capital, and the price of capital generally reflects governance structures, including rules of corporate law as well as charter

278 See Bebchuk, supra note 157 , at $26-43$ (implying that value-increasing amendments unfavorable to managers are unlikely to be proposed by managers or shareholders). 
and bylaw provisions. ${ }^{279}$ Over time, structures that maximize investor wealth reduce the cost of capital and are naturally selected from a diverse array of structural experiments. ${ }^{280}$ Except where structural terms create externalities or are both unpriced and systematically suboptimal, corporate law should not impose mandatory rules that constrain this competitive process, but instead should consist of only nonmandatory default rules and allow firms and investors (prior to investment) to negotiate terms that vary from default rules. ${ }^{281}$ The same logic weighs against imposing mandatory but nonbinding rules, as with current discount law.

279 See generally R.A. BREALEY, AN INTRODUCTION TO RISK AND RETURN FROM COMMON STOCKS 25-46, 53-61 (2d ed. 1983) (describing the relationship between risk and return for common stocks); EASTERBROOK \& FISCHEL, supra note 22, at 1-39 (describing the purpose of the corporate contract); Ronald J. Gilson \& Reinier H. Kraakman, The Mechanisms of Market Efficiency, 70 VA. L. REV. 549, 565-92 (1984) (describing capital market mechanisms that potentially explain market efficiency); Symposium, The Structure and Governance of Enterprise, 27 J. FIN. ECON. 1 (1990) (examining changes occurring in the structure, management, and governance of business enterprises). The EMH, which in its "strong" and "semi-strong" forms is crucial to the view that corporate structures are priced efficiently, is not a consensus view. See supra note 190 (questioning the efficiency of capital markets). Few would dispute, however, the notion that capital market pricing generally reflects governance structures, particularly at the stage of initial public offerings for large companies. See Gordon, supra note 123, at 1557-61 (arguing that initial public offering prices are generally efficient); $c f$. Steven L. Jones \& Jeffry M. Netter, Efficient Capital Markets, in ENCYCLOPEDIA OF ECONOMICS 569, 569-73 (David R. Henderson ed., 1993) (noting that "initial stock price response to new information is at least in the correct direction").

280 See EASTERBROOK \& FISCHEL, supra note 22, at 4-7 (arguing that "self-interested entrepreneurs and managers ... are driven to find the devices most likely to maximize net profits"); Fred S. McChesney, Economics, Law and Science in the Corporate Field: A Critique of Eisenberg, 89 COLUM. L. REV. 1530, 1534-38 (1989) (arguing in favor of the economic or contractarian view of the function of corporate law); Ralph $\mathrm{K}$. Winter, The "Race for the Top Revisited": A Comment on Eisenberg, 89 COLUM. L. REV. 1526, 1526-29 (1989) (rebutting Eisenberg's argument that capital markets fail to discipline management). But see Eisenberg, supra note 123, at 1500-05 (arguing that capital markets do not sufficiently constrain firms to have a significant disciplinary impact on governance structures).

In addition to capital markets, other markets play a role in aligning the structure of a firm with the interests of investors. These markets include the market for corporate charters among the states, the market for corporate control, and the managerial labor market. See RoMANo, supra note 47, at 32-51 (describing and assessing evidence for the impact of a market for corporate charters); Eugene F. Fama, Agency Problems and the Theory of the Firm, $88 \mathrm{~J}$. Pol. ECON. 288, 290-95 (1980) (describing the market for corporate control and the managerial labor market). But see Black, supra note 123, at 571 (arguing that small IPOs may not be priced efficiently and that post-IPO discipline by the capital markets, labor markets, product markets, and market for corporate control is inefficient).

${ }^{281}$ See EASTERBROOK \& FISCHEL, supra note 22, at 35 (arguing that "[t] $]$ here is no reason why [the law] should be used to impose a term that defeats actual bargains"); Lucian Arye Bebchul, The Debate on Contractual Freedom in Corporate Law, 89 ColUM. L. REV. 1395, 1404-08 (1989) (summarizing arguments against mandatory corporate governance structures at the initial charter stage and noting exceptions for externalities and systematic mispricing); David D. Haddock et al., Property Rights in Assets and Resistance to Tender Offers, 73 VA. 
If corporate structures are efficiently priced, variations are at worst neutral from a shareholder perspective because investors will only pay for what they receive. Innovations can thus benefit the firms and investors involved in a new structure by permitting them their structure of choice. Innovations may also benefit the public generally because efficient structural innovations are a matter of public record and can be copied, leadiing to spillover effects if useful.

Part III.D raised the possibility of systematic mispricing of minority share prices based on a general misunderstanding regarding the Delaware rule on discounts as a possible answer to the discount puzzle. ${ }^{282}$ As noted, however, such an answer conflicts with the EMH, and the hypothesis remains unproven. More to the point, the simple "fix" to the possibility of overpayment would be for Delaware courts to adopt a predictable default rule rather than imposing an unpredictable mandatory rule. Parts III.B and III.C provide independent, plausible answers to the discount puzzle. Neither transaction costs nor network externalities in themselves provide separate reasons for imposing a mandatory discount rule on firms and investors, and the possibility of innovation externalities-if anything-favors permitting or encouraging greater latitude for innovation to help partially offset the possibility of less-than-optimal innovation caused by innovation externalities. $^{283}$

Absent a compelling reason to do otherwise, and given that nothing in DGCL section 262 or its legislative history suggests that Delaware courts should do otherwise, Delaware courts should abandon the blanket, mandatory rule rejecting all "shareholder level" discounts formulated in Cavalier Oil. $^{284}$ Rather, courts should generally reject discounts for the policy reasons discussed earlier in this Part, but permit discounts when clear evidence establishes that a particular firm and its investors reasonably expected a discount to be applied, on the basis of ex ante bargaining in the form of pricesetting or actual negotiations. ${ }^{285}$ That the efficiency arguments in Part IV.A

L. REV. 701, 733-36 (1987) (arguing in favor of nonmandatory default rules); McChesney, supra note 280, at 1534-38 (same).

${ }^{282}$ See supra notes $168-81$ and accompanying text (discussing the overpayment hypothesis as an explanation for the discount puzzle).

${ }^{283}$ See Marcel Kahan, The Qualified Case Against Mandatory Terms in Bonds, 89 Nw. U. L. REV. 565, 599-600 (1995) (discussing the phenomenon of innovation externalities).

284 Cavalier Oil Corp. v. Harnett, 564 A.2d 1137, 1144 (Del. 1989).

285 This argument should be distinguished from the arguments made supra Part IV.E that shareholder expectations should not alone be determinative of which default rule should be chosen on discounts. In those arguments, expectations were ambiguous because both the firm and investors were silent about freeze-out pricing. See supra Part IV.E. Here, by contrast, a firm would be required to clearly specify an altemative rule for it to be upheld. 
are uncertain at best, and that either rule represents a trade-off between competing efficiency interests, also suggests that whichever rule is chosen should remain nonmandatory. Permitting the inclusion of discounts in appropriate cases will continue to protect minority shareholders, but protect them in an appropriate way by satisfying their reasonable investment expectations, and it will provide corporations and investors with the flexibility to vary from this norm if they wish to do so. In any instance where a rule including discounts would be applied, full disclosure of the effects of the rule, together with appropriate charter provisions to put subsequent investors on notice, should of course be required.

To decide whether shareholder expectations are clearly evidenced, consider how a firm could contract around a default rule on discounts. Rules affecting minority discounts may arise at the time of initial issuance and in "midstream changes" through charter or bylaw amendments. A midstream change can occur in either a setting where no controlling shareholder exists, so that "control" is dispersed in the public market among minority shareholders, or where a controlling shareholder or parent company exists.

A firm-specific rule including discounts resulting from an initial issuance would appear to provide the best case for applying a rule permitting discounts. ${ }^{286}$ Where minority shares are issued in a public offering or private placement, the issuing firm should have the flexibility to contract with its shareholders in such a way that, should it pursue a transaction triggering

With respect to discounts other than minority discounts, shareholders investing in certain types of stock, upon full disclosure, will form investment expectations regarding the value of the stock that warrants consideration in fair value determinations. In the context of initial share issuances, the presumption is that such investors have consented to a rule including discounts (or premiums, where appropriate) that takes into account the special characteristics of such stock:

(1) shares issued with lesser or greater voting rights (which should not be valued identically with shares having normal voting rights, despite (in theory) having the same pro rata residual claim in liquidation);

(2) shares subject to an otherwise unobjectionable written agreement among shareholders (or between a company and particular shareholders) restricting share transfers (for example, buy/sell agreements, agreements granting the corporation a right of first refusal, and agreements prohibiting transfer to a particular class of potential investors), or altering the rights upon transfer of shares (for example, time-phased voting shares, which have differing voting rights depending upon how long they have been held by the shareholder and which should not be valued identically with freely transferable shares); and

(3) shares of privately held companies (which should not be valued identically with shares of an identical company - in other words, marketability discounts are valid).

Where investors are aware of such unique attributes at the time of investment, discounts or premiums to reflect the unique attributes of such shares should be included to satisfy the reasonable investment expectations of both the issuing firm and the investors.

${ }^{286}$ See Gordon, supra note 123, at 1556-64 (reaching a similar conclusion with respect to IPOs generally). 
a fair value determination, fair value would include a discount to reflect the minority status of such shares. Inclusion of discounts in such circumstances would not appear to create any identifiable externality, nor would discounts appear to present any special capital market pricing difficulty. ${ }^{287}$ All other things being equal, expanding structural choices for firms and investors seems sensible on its face, ${ }^{288}$ and permitting corporate law to include discounts, if consistent with investors' reasonable expectations, would allow the capital markets to correct for any default rule inefficiencies. ${ }^{289}$

In a midstream change where a controlling shareholder exists, there will be little basis for concluding that minority shareholders consented to the change. Disclosure relating to the change and technical board and shareholder approval requirements will not prevent a controlling shareholder from effecting a midstream change that represents a pure wealth transfer from minority shareholders. Absent judicial restraint, controlling shareholders, by definition, have the ability to force approval of charter amendments that transfer value from minority shareholders to controlling shareholders. Permitting such midstream changes would, in effect, be permitting value diversion by controlling shareholders and could be expected to reduce ex ante share value. ${ }^{290}$ Even in a situation in which minority shareholders bought their shares expecting that a controlling shareholder would exist, as in "partial carve-outs," or IPOs of minority stakes, minority investors do not expect that controlling shareholders will be unconstrained in their technical ability to propose and implement midstream changes. ${ }^{291}$ A charter amend-

${ }^{287}$ As discussed in Part IV.F, supra, where market prices are available, basing fair value determinations on such prices, which reflect an implied minority discount, would appear to be easier for both judges to determine and capital markets to price. Cf. Hermalin \& Schwartz, supra note 201, at 366-67 (arguing for a default rule including discounts on the ground that market prices are verifiable).

${ }^{288}$ See Charles J. Goetz \& Robert E. Scott, The Limits of Expanded Choice: An Analysis of the Interactions Between Express and Implied Contract Terms, 73 CAL. L. REV. 261, 262 (1985) (describing the "Expanded Choice postulate"); Gordon, supra note 123, at 1553 (same).

289 A third argument for permitting firms and investors to vary default rules is that doing so protects them from the risk that mandatory government regulation serving some end not endorsed by firms or investors will be imposed through corporate law. See Gordon, supra note 123, at $1553 \mathrm{n} .15$ (explaining that the "opt out" principle protects parties against legislative regulation or delay); see also ROMANO, supra note 47 , at $42-44$ (describing ways in which Delaware "bonds" to firms and investors by making it difficult for the Delaware legislature to "renege" on implicit promises of adopting corporate laws that maximize investor wealth).

${ }^{290}$ See supra Part IV.A.5 (explaining that uncertainty and asymmetric information will increase capital cost and decrease share value).

291 The Delaware Supreme Court's recent split decision in Williams v. Geier demonstrates that Delaware's highest court has, for the moment, decided that such coerced shareholder votes do not present any per se problem. See Williams v. Geier, 671 A.2d 1368, 1376- 
ment permitting the majority to freeze out the minority at a discounted price (less than "fair value") would appear to be a classic instance in which the entire fairness test should apply, regardless of whether the amendment is technically approved by the requisite majority. It is difficult to imagine from either an ex ante or an ex post perspective how to defend a midstream charter amendment that simply lowers the fair price that control persons would need to pay in future conflict transactions.

That leaves one final, difficult case: midstream changes approved by minority shareholders in situations not involving controlling shareholders. Specifically, should a rule including discounts be permitted to be added to a charter after a company is already a public company, whether isolated from, or in anticipation of, a shareholder-approved control acquisition? Recent academic commentary has suggested that approval of midstream charter changes may be coerced by management through agenda control and "bundling" a charter change with a "sweetener" such as a special dividend, even absent a controlling shareholder. ${ }^{292}$ Moreover, collective action problems of the sort that make tender offers potentially coercive may impair a fully consensual shareholder vote. ${ }^{293}$ Because management of a public company that lacks a controlling shareholder is often in a position to propose and implement a type of conflict transaction (an $\mathrm{MBO}$ ) that raises precisely the same types of issues as conflict transactions sponsored by controlling shareholders, midstream changes sponsored by management should also be suspect.

77 (Del. 1996) (upholding stockholder approval of an amendment in the absence of unilateral board action or disenfranchisement). In Geier, however, the majority opinion acknowledged that the "entire faimess" standard might apply to certain types of charter amendments. See id. at 1378 (giving various reasons why shareholder-approved charter amendments might be subject to entire faimess review and asserting that those reasons were not applicable in the case at hand); see also id. at 1386-88 (Hartnett, J., dissenting) (arguing strenuously that "entire faimess" review was appropriate in the instant case).

${ }^{292}$ See Gordon, supra note 123, at 1573-80 (discussing the risk of opportunistic charter amendments); see also Lucian Arye Bebchuk, Limiting Contractual Freedom in Corporate Law: The Desirable Constraints on Charter Amendments, 102 HARV. L. REV. 1820, 1823-25 (1989) (arguing for substantial limits on midstream changes in governance structures and identifying issues which define those limits). But see Romano, supra note 130, at 1606-13 (disputing that risks of opportunistic charter amendments are serious).

${ }^{293}$ See Two-Tier Tender Offer Pricing, Exchange Act Release No. 21,079, [1984 Transfer Binder] Fed. Sec. L. Rep. (CCH) ๆ 83,637, at 86,916 (June 21, 1984) (noting that shareholders often act against their beliefs due to uncertainty and the desire to minimize the risk of change); Lucian Arye Bebchuk, The Pressure to Tender: An Analysis and a Proposed Remedy, 12 DEL. J. CORP. L. 911, 924 (1987) (explaining that rational shareholders may make less efficient tender decisions because they "cannot coordinate their actions"); Lucian Arye Bebchuk, Toward Undistorted Choice and Equal Treatment in Corporate Takeovers, 98 HARV. L. REV. 1693, 1729-31 (1985) (explaining that shareholders' inability to coordinate action is among the causes of tender decision distortion); Michael Bradley, Interfirm Tender Offers and the Market for Corporate Control, 53 J. BUS. 345, 349-56 (1980) (explaining the "prisoners' dilemma" facing shareholders in an interfirm tender offer). 
MBOs concededly face market and legal hurdles that freeze-outs do not: the Revlon doctrine generally applies to $\mathrm{MBOs,} \mathrm{effectively} \mathrm{requiring} \mathrm{some}$ form of market check or auction before an MBO can be closed. ${ }^{294}$ Nonetheless, a rule permitting discounts would present a paradigm case of a charter change that poses a conflict between control persons and minority shareholders, similar to the dual class recapitalizations that enjoyed a surge of popularity in the mid-1980s. Although the question is not free from doubt, and the debate over midstream changes is too lengthy to review in detail here, concerns about midstream changes combine with concerns about freeze-outs themselves to suggest that, on balance, companies should not be permitted to adopt rules to include discounts at any time other than at initial issuance.

\section{CONCLUSION}

Having concluded in Part IV that Delaware courts should continue to reject minority discounts, it may be worthwhile to end by briefly considering how courts might go about the difficult business of attempting to differentiate between minority discounts and control premiums, and consequently how they might avoid making the same mistakes that have confused past Delaware decisions on fair value.

As noted in Part I, control premiums and minority discounts are intimately related - either they are used synonymously, or they are used to represent distinct but overlapping concepts. ${ }^{295}$ As argued in Part I, some Delaware courts have taken the pro rata value doctrine to prohibit explicit "second-stage" adjustments of any kind, whether premiums or discounts. As a result, those courts have produced fair value determinations that reflect implicit discounts, notwithstanding that the pro rata value doctrine nominally prohibits discounts. ${ }^{296}$ Other Delaware courts have recognized that control premiums and minority discounts are distinct in principle and have attempted to exclude some portion of a control premium without imposing what those courts viewed as a minority discount. ${ }^{297}$ Unfortunately, those

294 See Revlon, Inc. v. MacAndrews \& Forbes Holdings, Inc., 506 A.2d 173, 185 (Del. 1985) (announcing the Revlon doctrine); see also Mills Acquisition Co. v. Macmillan, Inc., 559 A.2d 1261, 1280-88 (Del. 1988) (applying Revlon to MBOs).

295 See supra Part I.D.2 (discussing the concepts of control premiums and minority discounts).

296 See supra Parts I.D.1-.2 (explaining how implicit discounts have been granted despite the fair value doctrine); Part I.D.3 (discussing cases granting implicit discounts).

297 See supra Part I.D.2.b (explaining the distinction); Part I.D.3 (analyzing case law confusion with respect to the distinction); see also Coffee, supra note 77 (making the same point by distinguishing expropriation value from synergy value in the context of sales of control by controlling shareholders). 
courts have provided only general guidance regarding how to calculate or even understand what portion of the control premium must be excluded, and what portion must be included to eliminate the implicit minority discount. ${ }^{298}$

As an initial matter, Delaware law on fair value would be improved simply by reformulating the pro rata value doctrine, at least as it has been applied to date. Of course, a fair value determination should include a valuation of the corporation as a whole (where feasible, such as through a DCF analysis). Courts should recognize that various valuation techniques, such as market-price-based valuations, already impound minority discounts, whereas other techniques, such as valuations based on control acquisition prices, impound full control premiums, including synergy value specific to the future transactions, as well as pure control value. A more flexible approach-more in keeping with the spirit of Weinberger $v$. UOP, Inc. ${ }^{299}$ would not reject the valuation methodologies which impose full control premiums, but neither would it prohibit "adjusting" reference values produced by such methodologies to eliminate nonincludable elements.

Nevertheless, a court making a fair value determination needs a reliable method for choosing the appropriate adjustments. Recall what gives control shares greater value than minority shares: expropriation value, synergy value, and pure control value. ${ }^{300}$ As a doctrinal matter, DGCL section 262 appears to prohibit inclusion of synergy value because, by definition, such value arises out of the transaction triggering the appraisal. ${ }^{301}$ It is true that in Weinberger, and more recently in Technicolor, the Delaware Supreme Court has interpreted the statutory exclusion narrowly. ${ }^{302}$ Nevertheless, the synergies included in fair value determinations in those two cases were limited to synergies that both were "known" as of the date of the merger and were related to steps that had previously been taken by the controlling shareholder, so that the synergies were plausibly "part of" the company be-

${ }^{298}$ See supra Part I.D.3 (explaining case law confusion with respect to the distinction between minority discounts and control premiums).

299457 A.2d 701 (Del. 1983).

300 See supra Part I.D.2.a (defining these terms and illustrating their conceptual bases).

301 See DEL. CODE ANN. tit. 8, § 262 (1991 \& Supp. IV 1996) (directing courts to determine fair value "exclusive of any element of value arising from the accomplishment or expectation of the merger").

302 See Weinberger v. UOP, Inc., 457 A.2d 701, 713-14 (Del. 1983) (interpreting DGCL section 262 as barring only speculative elements of future value); Cede \& $\mathrm{Co}$. v. Technicolor, Inc., Civ. A. No. 7129, 1990 WL 161084, at *20 (Del. Ch. Oct. 19, 1990) (interpreting DGCL section 262 and Weinberger as barring synergy value), rev'd, 684 A.2d 289, 298-300 (Del. 1996) (instructing the lower court on remand that synergies must be included in fair value if, during the period between tender offer and freeze-out merger in a two-step takeover, the acquiror takes sufficient steps so that synergies are "known" and not "speculative" and are part of the company being valued). 
ing valued. It is unclear how far Delaware courts will push this reasoning in the face of the statutory exclusion-however narrow it may be said to be. Even if Delaware courts were prepared to reject a rigid application of the pro rata value doctrine, the inclusion of synergies that were still in the early planning stage, and so were speculative even if probable, would appear to be contrary to the appraisal statute. ${ }^{303}$

The remaining elements of a control premium, expropriation value and pure control value, by contrast, appear to be elements that could be considered by a court under Weinberger. ${ }^{304}$ For reasons discussed in Part IV, expropriation value should not be included in fair value. Pure control value is the most difficult element. It represents, so to speak, the value of pure control in a world of upright, law-abiding citizens, in which no expropriation value existed, and where no transaction-specific synergies were foreseeable. The efficiency arguments reviewed in Part IV suggest that, at least as a preliminary matter, such value should be included, and therefore, whenever minority share prices are adjusted upward to eliminate the impact of minority discount, the adjustment made should include all elements of a control premium except synergy values.

As a practical matter, courts are ill-equipped to distinguish between includable and excludable elements of a control premium, regardless of the resolution of the theoretical problems. ${ }^{305}$ Moreover, as noted by several Delaware courts, judges generally are not empowered or well-positioned to act as investigators and must instead depend upon litigants to brief the issues and provide factual data. ${ }^{306}$ Rather than attempting the impractical, therefore, courts might adopt the following procedural rule to guide fair value determinations: Where an adjustment to a reference value is proposed to eliminate elements of a control premium or minority discount in a fair value determination, the transaction sponsor will bear the burden of explaining why the adjustment is being made and how reliably it can be measured. Failure to meet this burden will result in acceptance of upward adjustments and rejection of downward adjustments.

303 See DEL. CODE ANN. tit. $8, \S 262(\mathrm{~h})$ (requiring consideration of "all relevant factors" but excluding consideration of value based on the accomplishment or expectation of merger); cf. 3 MODEL BUS. CORP. ACT ANN. § 13.01(3) (1997) (permitting the inclusion of increased or decreased post-merger value where it would be inequitable not to do so).

${ }^{304}$ See Weinberger, 457 A.2d at 713 (excluding from fair value only "speculative elements" arising from the "'accomplishment or expectation' of the merger").

305 See Kleinwort Benson Ltd. v. Silgan Corp., Civ. A. No. 11107, 1995 WL 376911, at *4 (Del. Ch. June 15, 1995) (noting the possibility of arbitrariness in adjusting for a minority discount).

${ }^{306}$ See, e.g., In re Appraisal of Shell Oil Co., Civ. A. No. 8080, 1990 WL 201390, at *5 (Del. Ch. Dec. 11, 1990) (noting that the parties, not the judge, have the responsibility to find and present proof). 
Such a procedural rule would be consistent with traditional Delaware law in entire fairness litigation that places the burden of proving entire fairness on the transaction sponsors. ${ }^{307}$ It would permit control persons, at a minimum, to exclude the impact of synergy value if they could propose a reliable estimate of such synergies, based, for example, on a comparable transaction analysis. Such a rule also fits nicely with existing requirements of the duty of candor. ${ }^{308}$ Temptations to exaggerate the size of estimated synergy value would be tempered not only by the litigation process, but also by the securities laws, at least for control persons that have their own public shareholders who would be able to sue if the control persons knowingly disclosed higher than reasonably expected synergy values. Practitioners would develop and refine techniques for arriving at appropriate adjustments, and a body of case law would develop to assist practitioners in this process. Over time, Delaware corporate law would begin to reflect in practice what it purports to do in theory, and what appears to be most efficient- to exclude minority discounts in conflict transactions.

${ }^{307}$ See Weinberger, 457 A.2d at 703 (agreeing with the lower court's holding that 'the ultimate burden of proof is on the majority shareholder to show ... that the transaction is fair").

See Lynch v. Vickers Energy Corp., 383 A.2d 278, 281 (Del. 1977) (enunciating the duty of candor). 
Appendix A

Table of Cases

Cases Applying or Rejecting Minority Discounts, Marketability Discounts, or Control Premiums in Appraisal, Liquidation,

Statutory Buyout, and Entire Fairness Cases, through January 1999

\begin{tabular}{|c|c|c|}
\hline Case & Law & $\begin{array}{c}\text { Discount/Premium } \\
\text { Holding } \\
\end{array}$ \\
\hline $\begin{array}{l}\text { Ronald v. 4-C's Elec. Packaging, Inc., } \\
168 \text { Cal. App. 3d 290, } 214 \text { Cal. Rptr. } \\
225 \text { (Ct. App. 1985). }\end{array}$ & $\mathrm{CA}$ & $\begin{array}{l}\text { Rejects minority dis- } \\
\text { counts }\end{array}$ \\
\hline $\begin{array}{l}\text { Brown v. Allied Corrugated Box Co., } \\
154 \text { Cal. Rptr. } 170 \text { (Ct. App. 1979). }\end{array}$ & $\mathrm{CA}$ & $\begin{array}{l}\text { Rejects minority dis- } \\
\text { counts }\end{array}$ \\
\hline $\begin{array}{l}\text { Walter S. Cheesman Realty Co. v. } \\
\text { Moore, } 770 \text { P.2d } 1308 \text { (Colo. App. } \\
\text { 1988). }\end{array}$ & $\mathrm{CO}$ & $\begin{array}{l}\text { Rejects minority dis- } \\
\text { counts }\end{array}$ \\
\hline $\begin{array}{l}\text { Hintmann v. Fred Weber, Inc., } 1998 \\
\text { Del. Ch. LEXIS } 26(1998) .\end{array}$ & $\mathrm{DE}$ & \begin{tabular}{|l} 
Applies $20 \%$ control \\
premium
\end{tabular} \\
\hline $\begin{array}{l}\text { LeBeau v. M. G. Bancorporation Inc., } \\
1998 \text { Del. Ch. LEXIS } 9 \text { (1998). }\end{array}$ & $\mathrm{DE}$ & $\begin{array}{l}\text { Rejects methodology re- } \\
\text { flecting implicit minority } \\
\text { discount; accepts meth- } \\
\text { odology that includes } \\
\text { "control premium" aris- } \\
\text { ing from elements of } \\
\text { value other than syner- } \\
\text { gies }\end{array}$ \\
\hline $\begin{array}{l}\text { Metropolitan Life Ins. Co. v. Aramark } \\
\text { Corp., } 1998 \text { Del. Ch. LEXIS } 70 \text { (1998). }\end{array}$ & $\mathrm{DE}$ & $\begin{array}{l}\text { Rejects minority discount } \\
\text { in entire fairness case } \\
\text { triggered by reverse stock } \\
\text { split freeze-out }\end{array}$ \\
\hline $\begin{array}{l}\text { Connector Serv. Corp. v. Briggs, } 1998 \\
\text { U.S. Dist. LEXIS } 18864 \text { (N.D. Ill. } \\
\begin{array}{ll}\text { 1998). } & \end{array}\end{array}$ & $\mathrm{DE}$ & $\begin{array}{l}\text { An Illinois court applying } \\
\text { Delaware law rejects mi- } \\
\text { nority discount in entire } \\
\text { fairness case triggered by } \\
\text { reverse stock split freeze- } \\
\text { out }\end{array}$ \\
\hline
\end{tabular}




\begin{tabular}{|c|c|c|}
\hline Case & Law & $\begin{array}{c}\text { Discount/Premium } \\
\text { Holding }\end{array}$ \\
\hline $\begin{array}{l}\text { Cede \& Co. v. Technicolor, Inc., } 684 \\
\text { A.2d } 289 \text { (Del. 1996). }\end{array}$ & DE & $\begin{array}{l}\text { Holds that control pre- } \\
\text { mium (including synergy } \\
\text { value) must be included if } \\
\text { synergies are "part of" } \\
\text { company on merger date; } \\
\text { affirms rejection of mi- } \\
\text { nority discount }\end{array}$ \\
\hline $\begin{array}{l}\text { Kleinwort Benson Ltd. v. Silgan Corp., } \\
1995 \text { Del. Ch. LEXIS } 75 \text { (1995). }\end{array}$ & $\mathrm{DE}$ & $\begin{array}{l}\text { Adjusts market value } \\
\text { upward to eliminate im- } \\
\text { plicit minority discount; } \\
\text { refuses to include syn- } \\
\text { ergy value }\end{array}$ \\
\hline $\begin{array}{l}\text { Cooper v. Pabst Brewing Co., } 1993 \text { Del. } \\
\text { Ch. LEXIS } 91 \text { (1993). }\end{array}$ & $\mathrm{DE}$ & $\begin{array}{l}\text { Attempts to reject minor- } \\
\text { ity discount and to ex- } \\
\text { clude synergy value by } \\
\text { using "blended price" of } \\
\text { two-tier offer }\end{array}$ \\
\hline $\begin{array}{l}\text { Hodas v. Spectrum Technology Inc., } \\
1992 \text { Del. Ch. LEXIS } 52 \text { (1992). }\end{array}$ & $\mathrm{DE}$ & $\begin{array}{l}\text { Rejects minority and } \\
\text { marketability discounts }\end{array}$ \\
\hline $\begin{array}{l}\text { Rapid-American Corp. v. Harris, } 603 \\
\text { A.2d } 796 \text { (Del. 1992). }\end{array}$ & $\mathrm{DE}$ & $\begin{array}{l}\text { Applies control premium } \\
\text { at "corporate level" }\end{array}$ \\
\hline $\begin{array}{l}\text { Salomon Brothers Inc. v. Interstate Bak- } \\
\text { eries Corp., } 1992 \text { Del. Ch. LEXIS } 100 \\
\text { (1992). }\end{array}$ & $\mathrm{DE}$ & $\begin{array}{l}\text { Rejects minority discount } \\
\text { but also declines to adjust } \\
\text { market value upward to } \\
\text { eliminate implicit dis- } \\
\text { count }\end{array}$ \\
\hline $\begin{array}{l}\text { In re Radiology Assocs., Inc. Litig., } 611 \\
\text { A.2d } 485 \text { (Del. Ch. 1991). }\end{array}$ & $\mathrm{DE}$ & $\begin{array}{l}\text { Rejects upward adjust- } \\
\text { ment to eliminate implicit } \\
\text { discount; rejects control } \\
\text { premium }\end{array}$ \\
\hline $\begin{array}{l}\text { In re Appraisal of Shell Oil Co., } 1990 \\
\text { Del. Ch. LEXIS 199(1990). }\end{array}$ & $\mathrm{DE}$ & $\begin{array}{l}\text { Rejects minority dis- } \\
\text { count, but uses market } \\
\text { value (and thus implicit } \\
\text { discount) in part }\end{array}$ \\
\hline $\begin{array}{l}\text { Covalier Oil Co. v. } \\
1137 \text { (Del. 1989). }\end{array}$ & $\mathrm{DE}$ & $\begin{array}{l}\text { Rejects minority and } \\
\text { marketability discounts }\end{array}$ \\
\hline
\end{tabular}




\begin{tabular}{|c|c|c|}
\hline Case & Law & $\begin{array}{c}\text { Discount/Premium } \\
\text { Holding }\end{array}$ \\
\hline $\begin{array}{l}\text { Bell v. Kirby Lumber Corp., } 413 \text { A.2d } \\
137 \text { (Del. Ch. 1980). }\end{array}$ & $\mathrm{DE}$ & $\begin{array}{l}\text { Rejects third-party sale } \\
\text { value (and thus control } \\
\text { premium) }\end{array}$ \\
\hline $\begin{array}{l}\text { In re Olivetti Underwood Corp., } 246 \\
\text { A.2d } 800 \text { (Del. Ch. 1968). }\end{array}$ & $\mathrm{DE}$ & $\begin{array}{l}\text { Rejects third-party sale } \\
\text { value (and thus control } \\
\text { premium); uses Delaware } \\
\text { block method }\end{array}$ \\
\hline $\begin{array}{l}\text { Felder v. Anderson, Clayton \& Co., } 159 \\
\text { A.2d } 278 \text { (Del. Ch. 1968). }\end{array}$ & $\mathrm{DE}$ & $\begin{array}{l}\text { Applies } 10 \% \text { marketabil- } \\
\text { ity discount }\end{array}$ \\
\hline $\begin{array}{l}\text { Application of Del. Racing Assoc., } 213 \\
\text { A.2d } 203 \text { (Del. 1965). }\end{array}$ & $\mathrm{DE}$ & $\begin{array}{l}\text { Rejects third-party sale } \\
\text { value (and thus control } \\
\text { premium); uses Delaware } \\
\text { block method }\end{array}$ \\
\hline $\begin{array}{l}\text { Sporborg v. City Speciality Stores, } 123 \\
\text { A.2d } 121 \text { (Del. Ch. 1956). }\end{array}$ & $\mathrm{DE}$ & $\begin{array}{l}\text { Rejects control premium } \\
\text { in determining market } \\
\text { pricing using Delaware } \\
\text { block method }\end{array}$ \\
\hline $\begin{array}{l}\text { Sterling v. Mayflower Hotel Corp., } 93 \\
\text { A.2d } 107 \text { (Del. 1952). }\end{array}$ & $\mathrm{DE}$ & $\begin{array}{l}\text { Rejects control premium } \\
\text { in determining market } \\
\text { pricing using Delaware } \\
\text { block method }\end{array}$ \\
\hline $\begin{array}{l}\text { Tri-Continental Corp. v. Battye, } 74 \text { A.2d } \\
71 \text { (Del. 1950). }\end{array}$ & $\mathrm{DE}$ & $\begin{array}{l}\text { Applies } 25 \% \text { minority } \\
\begin{array}{l}\text { discount at "corporate } \\
\text { level" }\end{array}\end{array}$ \\
\hline $\begin{array}{l}\text { Atlantic States Constr., Inc. v. Beavers, } \\
\text { 314 S.E.2d } 245 \text { (Ga. Ct. App. 1984). }\end{array}$ & GA & $\begin{array}{l}\text { Applies minority discount } \\
\text { and marketability dis- } \\
\text { count, but cautions } \\
\text { against double-counting }\end{array}$ \\
\hline $\begin{array}{l}\text { Weigel Broad. Co. v. Smith, } 682 \text { N.E.2d } \\
745 \text { (Ill. App. Ct. 1996). }\end{array}$ & IL & $\begin{array}{l}\text { Refuses to overturn lower } \\
\text { court's application of } \\
50 \% \text { combined minority/ } \\
\text { marketability discount; } \\
\text { fair value determination } \\
\text { vested in trier of fact }\end{array}$ \\
\hline
\end{tabular}




\begin{tabular}{|c|c|c|}
\hline Case & Law & $\begin{array}{l}\text { Discount/Premium } \\
\text { Holding }\end{array}$ \\
\hline $\begin{array}{l}\text { Laserage Tech. Corp. v. Laserage Lab., } \\
\text { Inc., } 972 \text { F.2d } 799 \text { (7th Cir. 1992). }\end{array}$ & IL & $\begin{array}{l}\text { Refuses to overturn lower } \\
\text { court's rejection of mi- } \\
\text { nority discount; fair value } \\
\text { determination vested in } \\
\text { trier of fact }\end{array}$ \\
\hline $\begin{array}{l}\text { Stanton v. Republic Bank of S. Chicago, } \\
581 \text { N.E.2d } 678 \text { (Ill. 1991). }\end{array}$ & $\mathrm{IL}$ & $\begin{array}{l}\text { Refuses to overturn lower } \\
\text { court's acceptance of } 5 \% \\
\text { minority discount; fair } \\
\text { value determination } \\
\text { vested in trier of fact }\end{array}$ \\
\hline $\begin{array}{l}\text { Institutional Equip. \& Interiors, Inc. v. } \\
\text { Hughes, } 562 \text { N.E.2d } 662 \text { (2d Dist. Ill. } \\
\text { 1990). }\end{array}$ & IL & $\begin{array}{l}\text { Rejects both } 20 \% \text { mar- } \\
\text { ketability discount and } \\
30 \% \text { control premium as } \\
\text { a factual (not legal) mat- } \\
\text { ter }\end{array}$ \\
\hline $\begin{array}{l}\text { Independence Tube Corp. v. Levine, } 545 \\
\text { N.E.2d } 111 \text { (1st Dist. Ill. 1988). }\end{array}$ & IL & $\begin{array}{l}\begin{array}{l}\text { Applies } 20 \% \text { minority } \\
\text { discount }\end{array} \\
\end{array}$ \\
\hline $\begin{array}{l}\text { Johnson v. Hickory Creek Nursery, } 521 \\
\text { N.E.2d 236 (3d Dist. Ill. 1988). }\end{array}$ & IL & Rejects minority discount \\
\hline $\begin{array}{l}\text { Stewart v. D.J. Stewart \& Co., } 346 \\
\text { N.E.2d } 475 \text { (2d Dist. Ill. 1976). }\end{array}$ & IL & $\begin{array}{l}\text { Finds discount not inap- } \\
\text { propriate as a matter of } \\
\text { law }\end{array}$ \\
\hline $\begin{array}{l}\text { Ahlenius v. Bunn \& Humphreys, Inc., } \\
192 \text { N.E. } 824 \text { (2d Dist. Ill. 1934). }\end{array}$ & IL & $\begin{array}{l}\text { Includes discount in list } \\
\text { of permissible valuation } \\
\text { factors }\end{array}$ \\
\hline $\begin{array}{l}\text { Perlman v. Permonite Mfg. Co., } 734 \\
\text { F.2d } 1283 \text { (7th Cir. 1983). }\end{array}$ & IN & \begin{tabular}{|l}
$\begin{array}{l}\text { Applies } 15 \% \text { minority } \\
\text { discount }\end{array}$ \\
\end{tabular} \\
\hline $\begin{array}{l}\text { Richardson v. Palmer Broad. Co., } 353 \\
\text { N.W.2d } 374 \text { (Iowa 1984). }\end{array}$ & IA & Rejects minority discount \\
\hline $\begin{array}{l}\text { Woodward v. Quigley, } 133 \text { N.W.2d } 38 \\
\text { (Iowa 1965). }\end{array}$ & IA & Rejects minority discount \\
\hline $\begin{array}{l}\text { Moore v. New Ammest, Inc., } 630 \text { P.2d } \\
167 \text { (Kan. App. 1981). }\end{array}$ & $\mathrm{KA}$ & $\begin{array}{l}\text { Applies } 20 \% \text { minority } \\
\text { discount }\end{array}$ \\
\hline
\end{tabular}




\begin{tabular}{|c|c|c|}
\hline Case & Law & $\begin{array}{c}\text { Discount/Premium } \\
\text { Holding }\end{array}$ \\
\hline $\begin{array}{l}\text { Ford v. Courier-Journal Job Printing } \\
\text { Co., } 639 \text { S.W.2d } 553 \text { (Ky. Ct. App. } \\
\text { 1982). }\end{array}$ & KY & $\begin{array}{l}\text { Rejects minority dis- } \\
\text { count; applies market- } \\
\text { ability discount }\end{array}$ \\
\hline $\begin{array}{l}\text { In re Valuation of Common Stock of } \\
\text { McLoon Oil Co., 565 A.2d } 997 \text { (Me. } \\
\text { 1989). }\end{array}$ & $\mathrm{ME}$ & Rejects minority discount \\
\hline $\begin{array}{l}\text { American Gen. Corp. v. Camp, } 190 \text { A. } \\
225 \text { (Md. 1937). }\end{array}$ & $\mathrm{MD}$ & Rejects minority discount \\
\hline $\begin{array}{l}\text { BNE Mass. Corp. v. Sims, } 588 \text { N.E.2d } \\
14 \text { (Mass. App. Ct. 1992). }\end{array}$ & MA & $\begin{array}{l}\text { Rejects minority dis- } \\
\text { count; applies control } \\
\text { premium }\end{array}$ \\
\hline $\begin{array}{l}\text { Martignette v. Sagamore Mfg. Co., } 163 \\
\text { N.E.2d } 9 \text { (Mass. 1959). }\end{array}$ & MA & $\begin{array}{l}\text { Rejects implicit minority } \\
\text { discount }\end{array}$ \\
\hline $\begin{array}{l}\text { Pooley v. Makato Iron \& Metal, Inc., } \\
513 \text { N.W.2d } 834 \text { (Minn. Ct. App. 1994). } \\
\end{array}$ & $\mathrm{MN}$ & Rejects minority discount \\
\hline $\begin{array}{l}\text { Foy v. Klapmeier, } 992 \text { F.2d } 774 \text { (8th Cir. } \\
\text { 1993). }\end{array}$ & $\mathbf{M N}$ & Rejects minority discount \\
\hline $\begin{array}{l}\text { Spinnaker Software Corp. v. Nicholson, } \\
495 \text { N.W.2d } 441 \text { (Minn. Ct. App. 1993). }\end{array}$ & $\mathrm{MN}$ & Applies minori \\
\hline $\begin{array}{l}\text { MT Properties, Inc. v. CMC Real Estate } \\
\text { Corp., } 481 \text { N.W.2d } 383 \text { (Minn. Ct. App. } \\
\text { 1992). }\end{array}$ & $\mathrm{MN}$ & Rejects minority discount \\
\hline $\begin{array}{l}\text { Hernando Bank v. Huff, } 796 \text { F.2d } 803 \\
\text { (5th Cir. 1985). }\end{array}$ & MS & Applies minority discount \\
\hline $\begin{array}{l}\text { Hunter v. Mitek Indus., Inc., } 721 \text { F. } \\
\text { Supp. } 1102 \text { (E.D. Mo. 1989). }\end{array}$ & MO & $\begin{array}{l}\text { Rejects minority and } \\
\text { marketability discounts; } \\
\text { states that fair value de- } \\
\text { termination vested in trier } \\
\text { of fact }\end{array}$ \\
\hline $\begin{array}{l}\text { King v. FTJ, Inc., } 765 \text { S.W.2d } 301 \text { (Mo. } \\
\text { Ct. App. 1988). }\end{array}$ & MO & $\begin{array}{l}\text { Applies } 15 \% \text { minority } \\
\text { discount; states that fair } \\
\text { value determination } \\
\text { vested in trier of fact }\end{array}$ \\
\hline $\begin{array}{l}\text { Dreiseszun v. FLM Indus., Inc., } 577 \\
\text { S.W.2d } 902 \text { (Mo. Ct. App. 1979). }\end{array}$ & MO & Rejects minority discount \\
\hline $\begin{array}{l}\text { Rigel Corp. v. Cutchall, } 511 \text { N.W.2d } \\
519 \text { (Neb. 1994). }\end{array}$ & $\mathrm{NE}$ & Rejects minority discount \\
\hline
\end{tabular}




\begin{tabular}{|c|c|c|}
\hline Case & Law & $\begin{array}{c}\text { Discount/Premium } \\
\text { Holding } \\
\end{array}$ \\
\hline $\begin{array}{l}\text { Steiner Corp. v. Benninghoff, } 5 \text { F. Supp. } \\
\text { 2d } 1117 \text { (D. Nev. 1998). }\end{array}$ & NV & $\begin{array}{l}\text { Rejects explicit minority } \\
\text { discount; rejects control } \\
\text { premium; applies implicit } \\
\text { discount by using market } \\
\text { value; applies } 25 \% \text { mar- } \\
\text { ketability discount }\end{array}$ \\
\hline $\begin{array}{l}\text { Lawson Mardon Wheaton v. Smith, } 315 \\
\text { N.J. Super. } 32 \text { (1998). }\end{array}$ & $\mathrm{NJ}$ & $\begin{array}{l}\text { Rejects marketability dis- } \\
\text { count; rejects attempt to } \\
\text { apply upward adjustment } \\
\text { to eliminate implicit mi- } \\
\text { nority discount }\end{array}$ \\
\hline $\begin{array}{l}\text { McCauley v. Tom McCauley \& Sons, } \\
\text { Inc., } 724 \text { P.2d } 232 \text { (N.M. App. 1986). }\end{array}$ & NM & $\begin{array}{l}\text { Applies } 25 \% \text { minority } \\
\text { discount, states that fair } \\
\text { value determination vest- } \\
\text { ed in trier of fact }\end{array}$ \\
\hline $\begin{array}{l}\text { Friedman v. Beway Realty Corp., } 661 \\
\text { N.E.2d } 972 \text { (N.Y. 1995). }\end{array}$ & NY & $\begin{array}{l}\text { Rejects minority dis- } \\
\text { count; applies } 25 \% \text { mar- } \\
\text { ketability discount }\end{array}$ \\
\hline $\begin{array}{l}\text { Raskin v. Walter Karl, Inc., } 514 \\
\text { N.Y.S.2d 120 (2d Dept. 1987). }\end{array}$ & NY & Rejects minority discount \\
\hline $\begin{array}{l}\text { Blake v. Blake Agency, Inc., } 486 \\
\text { N.Y.S.2d 341 (2d Dept. 1985). }\end{array}$ & NY & $\begin{array}{l}\text { Rejects minority dis- } \\
\text { count; applies } 10 \% \text { mar- } \\
\text { ketability discount }\end{array}$ \\
\hline $\begin{array}{l}\text { Jones v. Healy, } 55 \text { N.Y.S.2d } 349 \text { (Spec. } \\
\text { Term 1945). }\end{array}$ & NY & Applies minority discount \\
\hline $\begin{array}{l}\text { Brown v. Hedahl's- } Q B \text { \& } R, \text { Inc., } 185 \\
\text { N.W.2d } 249 \text { (N.D. 1971). }\end{array}$ & ND & $\begin{array}{l}\text { Rejects control premium } \\
\text { in "reconstructing" mar- } \\
\text { ket price }\end{array}$ \\
\hline $\begin{array}{l}\text { Armstrong v. Marathon Oil Co., } 513 \\
\text { N.E.2d 776 (Ohio 1987). }\end{array}$ & $\mathrm{OH}$ & $\begin{array}{l}\text { Applies implicit minority } \\
\text { discount }\end{array}$ \\
\hline $\begin{array}{l}\text { Woolfv. Universal Fidelity Life Ins. Co., } \\
849 \text { P.2d } 1093 \text { (Okla. Ct. App. 1992). }\end{array}$ & OK & Rejects minority discount \\
\hline $\begin{array}{l}\text { Columbia Management Co. v. Wyss, } 765 \\
\text { P.2d } 207 \text { (Or. Ct. App. 1988). }\end{array}$ & OR & $\begin{array}{l}\text { Rejects minority dis- } \\
\text { count; applies } 33 \% \text { mar- } \\
\text { ketability discount }\end{array}$ \\
\hline $\begin{array}{l}\text { Charland v. County View Golf Club, } \\
\text { Inc., } 588 \text { A.2d } 609 \text { (R.I. 1991). }\end{array}$ & RI & $\begin{array}{l}\text { Rejects minority and } \\
\text { marketability discounts }\end{array}$ \\
\hline
\end{tabular}




\begin{tabular}{|l|l|l|l|}
\hline Case & Law & \multicolumn{1}{|c|}{$\begin{array}{l}\text { Discount/Premium } \\
\text { Holding }\end{array}$} \\
\hline $\begin{array}{l}\text { In re 75,629 Shares of Common Stock of } \\
\begin{array}{l}\text { Trapp Family Lodge, Inc., 1999 Vt. } \\
\text { LEXIS 5(Vt. 1999). }\end{array}\end{array}$ & $\begin{array}{l}\text { Applies 30\% control } \\
\text { premium }\end{array}$ \\
\hline $\begin{array}{l}\text { Robblee v. Robblee, 841 P.2d 1289 } \\
\text { (Wash. Ct. App. 1992). }\end{array}$ & WA & Rejects minority discount \\
\hline
\end{tabular}


